\title{
New myocardial marker proteins in acute myocardial infarction : quantitative aspects : release patterns of cellular enzymes and proteins in plasma following acute myocardial infarction
}

Citation for published version (APA):

Kragten, J. A. (1998). New myocardial marker proteins in acute myocardial infarction : quantitative aspects : release patterns of cellular enzymes and proteins in plasma following acute myocardial infarction. [Doctoral Thesis, Maastricht University]. Dekker \& van de Vegt en Van Gorcum. https://doi.org/10.26481/dis.19980313jak

Document status and date:

Published: 01/01/1998

DOI:

10.26481/dis.19980313jak

Document Version:

Publisher's PDF, also known as Version of record

Please check the document version of this publication:

- A submitted manuscript is the version of the article upon submission and before peer-review. There can be important differences between the submitted version and the official published version of record. People interested in the research are advised to contact the author for the final version of the publication, or visit the DOI to the publisher's website.

- The final author version and the galley proof are versions of the publication after peer review.

- The final published version features the final layout of the paper including the volume, issue and page numbers.

Link to publication

\footnotetext{
General rights rights.

- You may freely distribute the URL identifying the publication in the public portal. please follow below link for the End User Agreement:

www.umlib.nl/taverne-license

Take down policy

If you believe that this document breaches copyright please contact us at:

repository@maastrichtuniversity.nl

providing details and we will investigate your claim.
}

Copyright and moral rights for the publications made accessible in the public portal are retained by the authors and/or other copyright owners and it is a condition of accessing publications that users recognise and abide by the legal requirements associated with these

- Users may download and print one copy of any publication from the public portal for the purpose of private study or research.

- You may not further distribute the material or use it for any profit-making activity or commercial gain

If the publication is distributed under the terms of Article $25 \mathrm{fa}$ of the Dutch Copyright Act, indicated by the "Taverne" license above,

Download date: 26 Apr. 2023 


\section{New myocardial marker proteins in acute myocardial infarction. Quantitative aspects}

Release patterns of cellular enzymes and proteins in plasma following acute myocardial infarction 
Legend to the picture:

The painting on the cover of this book is an artist's impression on one of the subjects of this thesis. It was created by A.E. van den Berg-Labooy, M.D.

(C) 1998 J.A. Kragten, Heerlen. The Netherlands.

Publisher: Dekker \& van de Vegt en Van Garcum, P. O. bax 43, 9400 AA Assen, The Netheriands Coverprint: Drukkerij Rosbeek BV, Nuth

Lay out and production: Ingrid Heller \& Hein Berendsen, Heerlen

All rights are reserved. No part of this publication may be reproduced or transmitted in any form or by any means, electronic or mechanical, induding photocopy, recording or any information storage or retrievol system, without permission in writing from the copyright awner.

ISBN 9023233611 


\section{New myocardial marker proteins in acute myocardial infarction. Quantitative aspects}

Release patterns of cellular enzymes and proteins in plasma following acute myocardial infarction

\section{Proefschrift}

ter verkrijging van de graad van doctor aan de Universiteit Maastricht

op gezag van de Rector Magnificus, prof, dr. A.C. Nieuwenhuijzen Kruseman, volgens het besluit van het College van Decanen,

in het openbaar te verdedigen

op vrijdag I 3 maart 1998 om 14.00 uur

door

Johannes Albertus Kragten

geboren te Utrecht in 1952. 


\section{Promotores}

prof. dr. M.P. van Dieijen-Visser

prof. dr. W. Th. Hermens

\section{Beoordelingscommissie}

prof. dr. P.J. Brombacher (voorzitter)

prof. dr. A. van der Laarse (Rijksuniversiteit Leiden)

prof. dr. E.O. Robles de Medina (Universiteit Utrecht)

prof. dr. G.J. van der Vusse

prof, dr. H.J.J. Wellens

Support for the publication of this thesis was obtained by kind contributions from the WCN and Holland Medical.

Financial support is acknowledged from ASTA Medica; Astra Pharmaceutica; Bard; Bayer; Boehringer Mannheim Nederland; Bristal-Myers Squibb; Byk Nederland; Cordis; Hoechst Marion Roussel; Knoll BASF Pharma; Lorex Synthelabo; Medtronic; MSD; Novartis Pharma; Parke-Davis; Rhone-Poulenc Rarer; Zeneca Farma. 
Aan mijn ouders

"Concardia res parvae crescunt" 


\section{Contents}

Chapter I

General introduction

\section{Chapter 2}

37

Quantification of cardiac troponin T release into plasma after acute myocardial infarction. Only fractional recovery compared with enzymes.

Kragten J.A., Hermens W.T. and Van Dieijen-Visser M.P.

Ann. Clin. Biochem. 1996; 33:1-10

\section{Chapter 3}

57

Cumulative tropinin $T$ release after acute myocardial infarction. Influence of reperfusion.

Kragten J.A., Hermens W.T. and Van Dieijen-Visser M.P.

Eur. J. Clin. Chem. Clin. Biochem. 1997; 35(6):459-67

\section{Chapter 4}

Distribution of myoglobin and fatty acid-binding protein in human cardiac autopsies.

Kragten J.A., Van Nieuwenhoven F.A., Van Dieijen-Visser M.P., Theunissen P.H.M.H., Hermens W.T. and Glatz J.F.C.

Clin. Chem. 1996; 42:337-8

\section{Chapter 5}

95

Estimation of myocardial infarct size from plasma myoglobin or fatty acidbinding protein. Influence of renal function.

Wodzig K.W.H., Kragten J.A., Hermens W.T., Glatz J.F.C. and Van Dieijen-Visser M.P.x Eur. J. Clin. Chem. Clin. Biochem. 1997; 35(3):191-8

\section{Chapter 6}

Summary and conclusions.

\section{Chapter 7}

Samenvatting en conclusies (summary in Dutch).

$\begin{array}{ll}\text { Appendix } & 133 \\ \text { List of publications } & 134 \\ \text { List of abbreviations } & 137 \\ \text { Dankwoord } & 139 \\ \text { Curriculum vitae } & 141\end{array}$


Chapter I

\section{General introduction}




\section{A. The syndrome of acute coronary insufficiency}

Coronary heart disease is the major cause of death and hospitalisation in most western countries. In the Netherlands in 1994 more than 51.000 people died from cardiovascular disease. This amounts to $39 \%$ of the total mortality in that year. In the same year about 750.000 people were hospitalised, of whom I 9.344 (16.3\%) men and $83.514(11.1 \%$ ) women, for cardiovascular disease, making it the most common cause of hospitalisation (1). In the southern and eastern part of Limburg, these figures were even higher: $23.1 \%$ for men and $16.9 \%$ for women (2). The standardised cardiac death rate in this part of the country is 368 per 100.000 inhabitants, which is 30 more than the average for the Netherlands (1). Evidently, cardiovascular disease is responsible for an important part of total numbers of hospital admission and therefore contributes substantially to the costs of health care.

The syndrome of acute coronary insufficiency represents a continuum of disease from unstable angina pectoris, impending infarction to acute myocardial infarction. As both treatment and clinical consequences vary between the different categories, accurate diagnosis in an early stage is of utmost importance (3). However, reliable differentiation between patients and reliable prediction of adverse outcome after acute myocardial infarction is not always possible. This is partly caused by the poor definition of the syndrome of unstable angina pectoris. Braunwald (4.5) defined 'unstable angina' in a clinical way in order to help the clinician in distinguishing between patients with high and low mortality rates. Nevertheless, the patient's clinical status does not necessarily correlate with his short-term prognosis (10). About $10-15 \%$ of the patients with acute myocardial infarction may arrive at the emergency room with non-diagnostic electrocardiograms $\left(E C G^{\prime} s\right)(1,12)$ and of all patients with chest pain referred to the emergency department, 2-5\% are released as 'non-cardiac' whilst suffering from an acute myocardial infarction (13).

When cells are injured by e.g. hypoxia, drugs, poisons, trauma or microorganisms, control of membrane permeability is weakened and cellular proteins pass through the cell membrane into interstitial space and reach the circulation. In the circulation, the proteins are distributed over plasma and several extravascular compartments and eventually eliminated by hepatic endocytosis or by renal clearance. Sometimes, these proteins are highly specific for the tissue from which they originate and, after the introduction of the first sufficiently sensitive assays in the 1950's the appearance of these key proteins in plasma has been used as a diagnostic tool for assessment of organ damage. In the special case of ischaemic death of cardiomyocytes, disruption of the cell membrane is a sudden, all-or-none process, and the cellular proteins are released simultaneously, irrespective of molecular weight or size. From the cardiac interstitial space, however, most proteins reach the circulation by direct diffusion into the microvessels, and this process is strongly dependent on molecular size. The time course of marker protein concentrations in plasma, the time-concentration curve, thus is not only dependent on the time course of disease, but also on molecular size, on futher diffusion of the protein into extravascular 
compartments and on the rate of protein elimination from plasma. Quantitative interpretation of time-concentration curves therefore requires a circulatory model with rate constants for protein entry, distribution and elimination. Recently, new marker proteins, allowing better diagnosis and risk stratification have been introduced $(3,6-9)$ and better understanding of the plasma kinetics of these markers may be helpful in solving problems of the cardiologist.

\section{B. Cardiac marker proteins as a tool for the cardiologist}

\section{The differential diagnosis}

When a patient suffering from chest discomfort is referred to the emergency department of a hospital, unnecessary hospitalisation of low risk patients should be prevented and unnecessary costs avoided. Moreover, patients who need emergency care will have to receive more attention and specific treatment. The consulting cardiologist has to decide to which of the next four groups the patient can be assigned:

- non-cardiac chest pain, caused by e.g. muscle pain, oesophagus spasm or pulmonary disease,

- reversible ischaemic pain due to chronic coronary insufficiency (stable angina pectoris),

- unstable angina pectoris or impending myocardial infarction,

- myocardial infarction.

Each of the syndromes mentioned above has its own specific therapeutic approach and should therefore correctly be diagnosed.

\section{Chest pain of non-cardiac origin}

Although chest pain or discomfort is one of the main manifestations of cardiac disease, it is critical to recognise that it may originate not only in the heart but also in a variety of non cardiac intrathoracic structures such as the aorta, pulmonary artery, bronchopulmonary tree, pleura, mediastinum, oesophagus and diaphragma. Other sources may be the tissues of the neck or thoracic wall, including the skin, thoracic muscles, cervicodorsal spine, costochondral junctions, breasts, sensory nerves or spinal cord. Finally, non cardiac pain may be caused by subdiaphragmatic organs such as the stomach, duodenum, pancreas and gall bladder (4).

A major problem is to differentiate between non-cardiac chest pain and cardiac ischaemia, presenting as unstable angina. This differentiation depends largely on a carefully drawn history from the patient presenting at the emergency department. Ample time must be taken and if needed supplemental tests performed. The 
consequences of proper interpretation of the patient's complaints are of great importance for decision making, i.e. either sending him home after reassurance or admitting him to the cardiac care unit.

\section{Stable angina pectoris}

Typically angina pectoris presents as a pressure or a choking feeling, often not a pain, and is related to a disbalance between oxygen demand and oxygen supply in the myocardium. This disbalance is generally caused by insufficient coronary blood supply, but sometimes by severe anaemia or serious valvular disease. The stability of this syndrome is reflected by the onset of complaints under reproductable circumstances and is related to stable underlying coronary pathology. The diagnosis stable angina pectoris has to be made solely by a carefully drawn medical history. Although many tests have been developed in cardiology, they cannot replace the history taken by an experienced doctor. The appropriate use of cardiac marker proteins is to supplement but not to replace a careful clinical examination.

\section{Unstable angina pectoris (UAP)}

Different definitions have been used for the diagnosis of unstable angina. Although Braunwald (5) made an extensive classification of UAP in order to stratify patients according to their clinical prognosis, this classification is not generally used in the clinic, because of its many subtypes. Conti et al. (14) introduced a more frequently used classification, enumerating the following categories:

- angina on effort of recent onset,

- angina on effort with a changing pattern (accelerated or crescendo angina),

- angina at rest,

- angina at rest, refractory to 24-48 hours of medical treatment.

It is known that $10-20 \%$ of the patients with unstable angina pectoris progress to acute myocardial infarction or cardiac death (15). Indicators allowing risk stratification for this group of patients are badly needed. Even slight ellevations in plasma concentrations of the enzyme creatine kinase-MB $\left(C K-M B_{\text {mass }}\right)$ or the heartspecific structural protein troponin $T(T n T)$, appeared to predict a bad outcome in patients with unstable angina pectoris (16-18). CK-MB mass is not absolutely heartspecific and increased values are not always associated with myocardial cell death (19-21). In these cases the new, sensitive and heart-specific markers can be of great value. Both troponin $\mathrm{T}$ (6-10) and troponin I ( $\mathrm{Tnl}$ ) (22,23) levels in patients with acute coronary syndromes may provide useful prognostic information and permit the early identification of patients with increased risk of death. Thanks to the availability of these new marker proteins, a shift from the rather undefined indication 'unstable 
angina pectoris' towards a better defined and confirmed diagnosis 'minimal myocardial damage' or 'acute myocardial infarction' may become possible.

\section{Acute myocardial infarction (AMI)}

The diagnosis of acute myocardial infarction has been defined by the World Health Organisation $(\mathrm{WHO}$ ) and requires at least two of the following criteria (24):

- ischaemic chest pain of more than 30 minutes duration,

- typical electrocardiographic changes (i.e. development of new Q-waves, $R$-wave reduction and ST-segment changes and/or T-wave changes),

- a time-dependent rise and fall of serum cardiac enzyme levels with a peak of at least twice the upper reference limit for CK-MB activity.

Traditionally the clinician first of all uses ECG criteria, of which persistent STsegment changes, together with a history of prolonged chest pain are the most sensitive $(25,26)$. An important advantage of the electrocardiogram is the fact that it can quickly be obtained, is inexpensive and can be interpreted by the clinician. However, in the absence of ST-segment elevation it can be difficult to differentiate between unstable angina and acute myocardial infarction $(25,26)$ especially in patients with ischaemia in the territory of the circumflex coronary artery, previous myocardial infarction and left bundle branch block. Some studies report that as much as 10-15\% of the patients with acute myocardial infarction may initially arrive at the emergency room with non-diagnostic ECG's (11,12). In the absence of such a diagnostic ECG, rapid and highly sensitive assays for new cardiac markers proteins like myoglobin, fatty acidbinding protein (FABP), CK-MBmass, troponin $T$ or troponin I have brought new possibilities for more accurate (early) diagnosis of acute myocardial infarction (27-30).

As discussed below, several release characteristics are important for the suitability of the cardiac marker proteins for (early) diagnosis of acute myocardial infarction. The sensitivity, specificity, negative and positive predictive value (see Table 1) of a single measurement change rapidly in the first hours after the onset of symptoms and are not the same for the different markers (9.31). Since not all patients seek medical attention at the time symptoms appear, the applicability of these new cardiac markers, showing different release characteristics after acute myocardial infarction, differs in each case. Based on the time after the onset of chest pain, a strategy for the use of the different cardiac markers is required.

\section{Detection of coronary reperfusion}

Once the diagnosis acute myocardial infarction is certain, therapeutic interventions will aim at (32):

- restoration of coronary blood flow to limit the amount of infarcted tissue, 
- prevention of coronary reocclusion,

- preservation of myocardial function.

Nowadays the administration of thrombolytic agents such as streptokinase and tissue-type plasminogen activator are routine procedures in the treatment of most patients suffering from acute myocardial infarction, unless this treatment is contraindicated because of increased risk of bleeding. In those patients, primary percutaneous transluminal coronary angioplasty (PTCA) should be considered, when major loss of myocardium is expected on the basis of ECG changes or clinical status of the patient. Although in large groups there seems to be no difference in mortality after treatment with either primary PTCA or thrombolysis (33), in individual cases one wants to be sure about the perfusion status of the infarct-related vessel. Although reperfusion is easily demonstrated after the PTCA procedure, after thrombolysis this would require coronary angiography, a costly procedure not without risk. Also, changes in clinical status like abrupt relief of pain, changes in ST-elevation or occurrence of reperfusion arrhythmias, do not always allow reliable assessment of coronary recanalisation (34.35). The cardiac marker proteins creatine kinase (CK), CK$M B_{\text {mass }}$, myoglobin and the troponins have been reported to identify recanalisation in a non-invasive way $(19,28,36-41)$. For reliable detection of coronary reperfusion from initial slopes of cardiac markers, blood samples should be taken every 15 minutes after start of treatment to estimate the initial slope (38-40). Zabel et al. investigated sensitivity and specificity of both clinical signs and different cardiac markers for the detection of reperfusion (Table 2) and showed that biochemical markers have additional value in deciding whether reperfusion has occurred (38). Using early initial slopes of serum markers to predict reperfusion, they found the best discriminating results using myoglobin. Compared to troponin $T$ or $C K-M B_{\text {mass }}$ initial slopes, myoglobin showed earlier rise, yielding a better negative predictive value and a higher area under the curve for non invasive prediction of coronary artery patency after thrombolytic therapy (38).

Abe et al. found a comparable accuracy of $92 \%$ to predict reperfusion from initial slope measurements for CK-MB mass and troponin $T$. Initial slopes were obtained from 15 minute samples during the first 90 minutes $(40)$. Laperche et al. showed that reliable early non-invasive diagnosis of patency after thrombolysis from plasma myoglobin or troponin $T$ is only possible in patients treated $>3$ hours after onset of symptoms by use of criteria derived from the relative increase over 90 minutes (39).

Until now no prospective studies have been carried out to demonstrate the clinical effectiveness of these markers for the individual patient in the coronary care unit. Further investigations on this subject are required. 


\section{Quantification of infarct size}

Assessment of the extent of ischaemic myocardial injury from cumulative release into plasma of cardiac marker proteins has been applied successfully in the evaluation of thrombolytic therapy after acute myocardial infarction $(43.47)$. These studies demonstrated that the favourable effects of such therapy, namely preservation of myocardial function and reduced mortality, can be explained by limitation of infarct size and this has stimulated interest in the quantitative interpretation of marker proteins and in the methodological aspects of such analysis $(48,49)$.

In most studies the cumulative protein release is computed with a twocompartment model for circulating proteins (Fig. 1). Using this model, the cumulative release of protein per litre of plasma from the onset of acute myocardial infarction $(t=0)$ up to time $t, Q(t)$, can be calculated from the following expression:

$$
Q(t)=C(\tau)+T E R \sigma_{0}^{j t} \exp \{-E R R(t-\tau)\} C(\tau) d \tau+F C R \sigma_{\sigma}{ }^{t} C(\tau) d \tau
$$

The three terms are the amount of released protein still present in plasma, the amount of extravasated protein and the amount of protein eliminated from plasma, respectively, all three expressed per litre of plasma. $C(t)$ is the plasma enzyme activity or protein concentration at time $t$, corrected by subtraction of the normal steadystate values $C_{s^{*}}$ from the actually measured values. The parameters TER, ERR and FCR are the fractional rate constants for transcapillary escape, extravascular return and catabolism of activity (see Fig. 1). This two-compartment model has been validated in the dog $(50.51)$.

In order to allow comparison of cumulative release (infarct size) for different cardiac proteins, total protein release per litre of plasma has to be divided by the protein content per gram wet weight of cardiac tissue. In this way, infarct size can be expressed in gram equivalents ( $\mathrm{g}$-eq) of heart muscle per litre of plasma:

Infarct size $(\mathrm{g}$-eq $/ \mathrm{L})=\frac{\text { cumulative protein release per litre }}{\text { protein content per gram wet weight of tissue }}$

It has been demonstrated that different cardiac enzymes such as $C K$, aspartate amino-transferase (ASAT) and a-hydroxybutyrate dehydrogenase $(\mathrm{HBDH})$ produce approximately similar estimates of infarct size in $\mathrm{g}$-eq of heart muscle per litre of plasma (52). Also, several clinical studies have produced convincing correlations between enzymatic and histologic estimates of infarct size (48,53-57) or between enzymatic infarct size and infarct size estimated from photon-emission computed tomography (58) or radionuclide estimates of myocardial infarct size (59). Apart from our data presented in chapters 4 and $5(60,61)$, however, no studies have been published on the quantification of troponin $T$ release after acute myocardial infarction and only 


\section{Figure I}

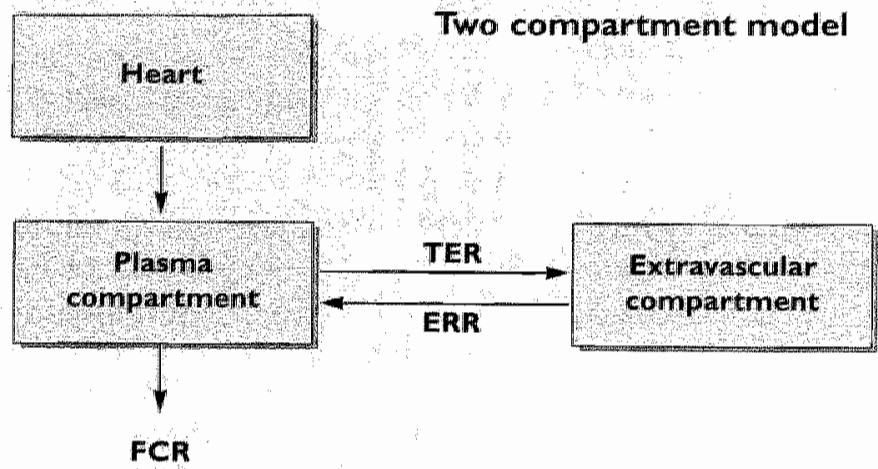

Cumulative protein release per litre plasma $\mathrm{Q}(\mathrm{t})$ :

Plasma activity if activity elliminated + extravascular activity

\section{Figure 2}

\section{Immuno-assays}

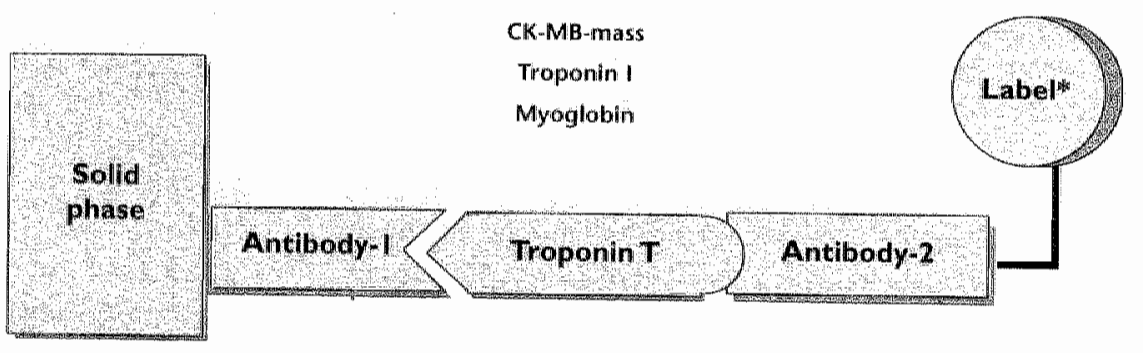

"Labels: enzymes, chemiluminescence, etc. 
few on the quantification of cumulative release of myoglobin (62-64) or fatty acid-binding protein (FABP) $(65,66)$.

\section{Value of marker proteins in patient management post myocardial infarction}

Quantification of infarct size, also from plasma concentrations of the new cardiac markers, can be important in large scale studies to evaluate the effect of thrombolytic therapy, but also in risk stratification of the individual patient. In order to decide on the optimal strategy for treatment in the patient surviwing the acute phase of acute myocardial infarction, the important question of his/her prognosis remains to be solved. Wellknown short term predictors of sudden death are rhythm disturbances and a low ejection fraction, but extensive angiographic studies have failed to predict long term progression of coronary disease (67). As patients with a small acute myocardial infarction resulting in little myocardial tissue damage and/or mild coronary lesions will have a low probability of cardiac morbidity or mortality, they should not be approached with expensive diagnostic techniques and treated by invasive and/or surgicall procedures.

\section{Relation between marker protein properties and the problem to be solved}

\section{The perfect myocardial marker protein does not exist}

An optimal cardiac marker cannot be defined, because the required properties may vary according to the circumstances. Performance of a marker in early versus late diagnosis, monitoring of reinfarction, indicating prognosis, infarct sizing, detection of reperfusion etc, will generally depend on different and sometimes mutually exclusive properties (28-31,75). The following general properties can be considered as important aspects of all cardiac markers:

- high cardiac specificity,

- low normal protein concentration in healthy controls,

- high amount of protein present in cardiac tissue,

- sensitivity of the analytical method used for its assay (low detection limit),

- assay time (preferably short enough to allow emergency analysis),

- molecular size (more rapid intravasation of smaller proteins).

- intracellular localisation (e.g. cytoplasmic versus structural protein),

- stability of the marker protein in the ischaemic tissue,

- elimination rate of protein from plasma, 
- unchanged protein content of cardiomyocytes in diseased myocardium,

- homogeneous distribution of protein throughout the heart.

The requirement of high cardiac specificity is selfevident. Many metabolic and circulatory processes can be altered during acute myocardial infarction, and protein release from other than cardiac sources should preferably not interfere with the primary diagnosis. But specificity alone is not enough to make an early unambiguous diagnosis. At the early onset the loss of enzymes or proteins from damaged cells may still be limited. In order to detect such minimal damage, the concentration of protein in the cardiomyocytes should be high, and the normal plasma concentration should be low, such that low values can be used for diagnosis. Also the protein assay should be sufficiently sensitive for accurate detection of these small elevations and the assay time should be short enough for early diagnosis. Originally, enzymatic assays took 30 60 minutes, but more sophisticated spectrophotometers soon allowed shorter assay times. More recently, analytical procedures for the accurate and highly sensitive measurement of protein mass concentrations became available. This opened possibilities for measurement of protein concentrations (e.g. CK-MB mass) instead of enzyme activities (Fig. 2). After cellular disruption of cardiac myocytes, smaller proteins will diffuse more rapidly into the blood vessels than large proteins and are therefore the preferred markers for early diagnosis.

Cytosolic proteins like LDH and CK have the advantage of being immediately and completely released after cellular membrane rupture. In contrast, structural proteins like Tnl must first be set free from their cellular structures and will therefore be released more slowly and often only partially. On the other hand, the cytosolic proteins mostly have general cellular functions and are therefore not strictly heartspecific. Not surprisingly, the truly heart-specific proteins are involved in heart-specific functions and are found in the contractile apparatus. It is also important that the proteins are not degraded in the ischemic tissue, or during transport from heart to plasma.

For detection of reinfarction, cardiac marker proteins like myoglobin or FABP, with a very short half-life in the blood, will be best suited, because an additional period of release will then be apparent as a new peak in plasma concentrations. In contrast, slowly eliminated proteins like $\mathrm{HBDH}$ or $\mathrm{TnT}$ are to be preferred if cumulative release has to be calculated from only a few samples, or in case of patients admitted to hospital after long time delays.

Degenerative changes will often be present in hearts of patients with AMI, especially in hypertrophic hearts, as observed in patients with a history of hypertension or previous cardiovascular disease (131). Part of these changes may consist of replacement of muscle by connective tissue, collagen or fat, and could leave the protein content of the myocytes unaltered. In that case, the release of cardiac markers into plasma could still be proportional to the amount of lost cardiomyocytes. However, pathological changes could also influence the amount of proteins present in the myocytes themselves. and this could alter the relation between the amount of released protein and lost muscle mass. 
Figure 3

The time course of some of the markers in plasma after onset of AMI

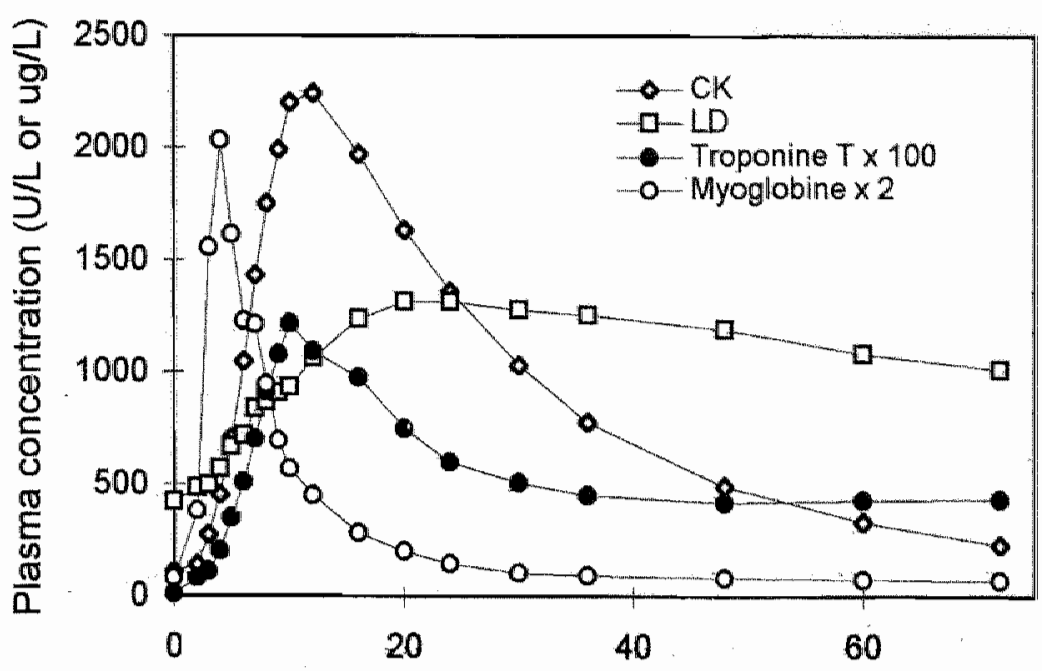

Time after the onset of symptoms (hours)

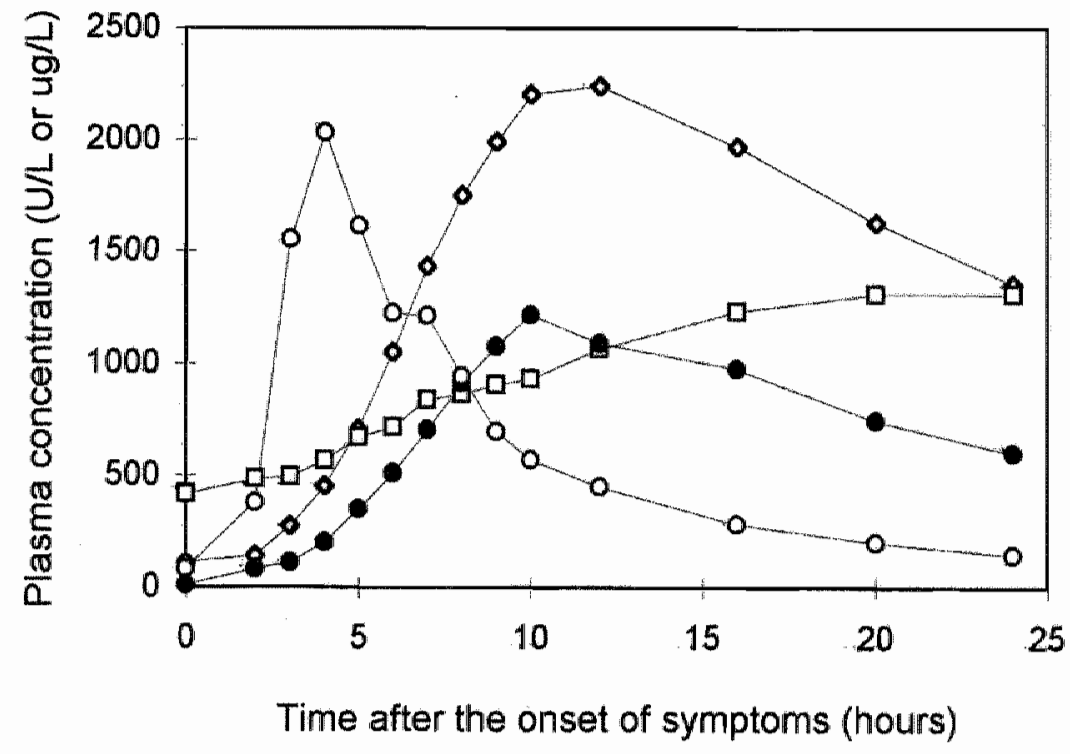

Plasma concentrations (U/L or ug/L) of CK (O), LDH (D), Troponin $T \times 100(0)$ and myoglobin $\times 2(O)$ in plasma following onset of AMl during 72 hours (3a) and 25 hours (3b). 


\section{The classical cardiac enzymes AST and LDH}

The history of modern marker proteins for acute myocardial infarction goes back as far as 1954 (68). Since then the rise and fall of serum levels of transaminase enzyme activities have been correlated to diseases of the liver, the heart and skeletal muscles $(68,69)$ and the request for biochemical analysis has become obligatory to the clinician. Because these markers lack specificity, they have limitations in clinical use. The same is true for lactate dehydrogenase (LDH) activity as a marker enzyme for acute myocardial infarction, as introduced by Wroblewskj et al. in $1955(70)$, because the biological function of $L D H$, that is, catalysis of the oxidation of lactate to pyruvate, is required in almost all body cells and $L D H$ is present accordingly.

Progress was made by the electrophoretic separation of LDH into five isoenzymes, each showing a different organ specificity. Especially the fast moving isoenzymes $L D H-1$ and $L D H-2$ appeared to be elevated in the serum of patients after acute myocardial infarction due to leakage of enzyme from damaged cardiac muscle cells. The fact that LDH-I and LDH-2 are capable of oxidizing the substrate $\alpha$-hydroxybutyrate much faster than the other $L D H$-isoenzymes, opened the way to measure these iso-enzymes separately by their $\alpha$-hydroxybutyrate dehydrogenase $(\mathrm{HBDH})$ activity (134). The time course of some of the markers in plasma after onset of $A M I$ is shown in figure 3.

\section{Creatine kinase $(\mathrm{CK})$ and its cardiac specific isoenzyme CK-MB}

CK $(82 \mathrm{kD})$ is an ubiquitous enzyme involved in cellular energy metabolism by catalysing the reversible transfer of a high energy phosphate group from adenosine triphospate (ATP) to creatine phosphate. The dimeric structure leads to three isoenzymes, CK-MM, CK-MB and CK-BB, by combination of muscle (M) and brain (B) subunits and clinical relevance has been extensively reviewed (28-30). The first reports on CK and myocardial infarction (71) were written in 1960, followed six years later by studies on the iso-enzymes CK-MM, CK-BB and CK-MB, of which CK-MB demonstrated remarkable cardiac specificity (72,73,74). The high myocardial $C K$ content and the cardiac specificity of CK-MB have made CK-MB the most widely used enzyme in confirming or excluding acute myocardial infarction. The consecutive rise and fall of cardiac enzyme levels and especially CK-MB in the serum of a patient referred to the emergency department for chest pain, is one of the three elements on which the final diagnosis of AMI is based (24). Increased plasma levels can be measured 6-10 hours after the onset of infarction, reaching a peak after 24 hours and returning to normal after $36-72$ hours (125). Accelerated release, with a peak value reached after 12-16 hours, is observed after thrombolytic treatment of AMI. The sensitivity of the CK-MB test was increased some years ago, when methodology for the immunochemical determination of the enzyme protein mass $(126,127)$ replaced the until then usual measurement of enzyme activity (Fig. 2). However, CK-MB ${ }_{\text {mass }}$ is not 
absolutely heart-specific and increased values are not always associated with myocardial cell death (19-21). At present CK-MB, either by measuring its activity or its mass, is still the most widely used cardiac marker (129). CK-MB mass has also been suggested as a marker to detect early reperfusion. However, myoglobin shows earlier rise, yielding a better negative predictive value and a higher area under the curve for non-invasive prediction of coronary artery patency after thrombolytic therapy compared to CK-MB ${ }_{\text {mass }}$ slopes (38).

\section{Myoglobin}

Myoglobin $(18 \mathrm{kD})$ is a low-molecular-weight protein, composed of a folded polypeptide chain (globin) and an iron-prorophyrin containing prosthetic group (haem). It is abundantly present in the cytoplasm of both cardiac and skelletal striated muscle cells, but not in the cytoplasm of smooth muscle cells. Myoglobin transports oxygen from the muscle cell membrane to the mitochondrion by reversible binding of oxygen to the haem prosthetic group $(106,107)$. After cardiac necrosis this low molecular mass protein is rapidly released from the tissue into the plasma. Myoglobin is therefore especially suitable for early detection of exclusion of myocardial infarction (96.108-110), for detection of reinfarction (108.111) and for early monitoring of cardiac reperfusion after thrombolytic therapy $(38,39,112-114)$.

Compared to high molecular mass cytoplasmic enzymes or proteins such as $\mathrm{HBDH}(136 \mathrm{kD})$ or $\mathrm{CK}$, myoglobin is more rapidly released into plasma, resulting in detectable increases in plasma as early as 2 hours after the onset of coronary occlusion (20,112). In the first hours after onset of acute myocardial infarction the specificity of the myoglobin test can be improved by serial testing to see if serum levels double within I-2 hours after an initial value is taken. For ruling out acute myocardial infarction, myoglobin appeared a better marker than CK-MB mass and troponin T from 3 until 6 hours, but the negative predictive value reached only $89 \%$ at 5 hours. In comparison the negative predictive value of CK-MB ${ }_{\text {mass }}$ was $95 \%$ at 7 hours (9).

Size estimation of myocardial infarction from serial serum myoglobin concentrations was first performed by Groth et al (62). In that study a reasonable correlation ( $r=0.72$ ) was found between the myoglobin estimates of infarct size compared to the CK-MB estimates of infarct size. Grottum et al. found a reasonable correlation $(r=0.72)$ between infarct size estimates from $C K$ and myoglobin plasma curves (64). The authors suggested myoglobin as an early marker for estimation of infarct size, because CK release starts 3-5 hours after acute myocardial infarction, whereas myoglobin release generally starts earlier and is already completed within 24 hours after acute myocardial infarction. In both studies infarct size was not expressed in gram equivalents of healthy myocardium per litre plasma (g-eq/L) and therefore quantitative comparison of infarct size measures obtained with CK, CK-MB and myoglobin was not possible. 
For myoglobin, it has been demonstrated that plasma levels are inversely related to the glomerular filtration rate $(r=0.62)$ and linearly related to serum creatinine $(r=0.63)$ in patients with renal disease (115). In this thesis infarct size estimates obtained from plasma release curves of low molecular mass markers like myoglobin or FABP, were compared to estimates obtained with the established infarct size markers $\mathrm{CK}$ and $\mathrm{HBDH}$ (chapters 4 and 5; (66.116-118)). Because chronic (87), but also temporary, worsening of renal function, may cause elevated serum levels of myoglobin, the influence of changes in renal function on quantification of infarct size from plasma myoglobin concentrations was also examined (66) (chapter 5).

\section{The troponins}

Troponins are myofibrillar proteins located at the contractile apparatus of striated muscle (76). This apparatus is composed of thick filaments, who contain the contractile myosin, and thin filaments, consisting of actin, tropomyosin and the troponin complex. Figure 4 shows how the thin filaments surround the thick filaments in a hexagonal array. The calcium-mediated interaction of actin and myosin is regulated by three proteins, together forming the troponin complex. Troponin $T$ (MW $37 \mathrm{kD}$ ) binds the troponin complex to tropomyosin $(76.77)$. In the healthy human heart muscle only a small part of $\mathrm{TnT}$ is found in the soluble cytoplasmic pool $(36,60,78)$. Approximately $94 \%$ is bound to the contractile apparatus $(36,60)$. Troponin C (MW 18 kD) binds to calcium and regulates the activation of thin filaments during skeletal and heart muscle contraction (76). Troponin I (MW $26 \mathrm{kD}$ ) inhibits muscle contraction in the absence of calcium and troponin C. By inhibiting the actomyosin ATP-ase, Tnl prevents the coupling of actin and myosin (76).

As skeletal muscle $\mathrm{TnC}$ is homologous to myocardial $\mathrm{TnC}$, injury to either tissue wil cause $\mathrm{TnC}$ release into plasma. Troponin $T$ and troponin 1, however, have distinctly different cardiac subforms which make them suitable for specific diagnosis of cardiac cell damage. Commercially available diagnostic assays have been developed using monoclonal antibodies for the exclusive recognition of myocardial TnT (79)- and Tnl-subtypes (80-82). Elevated troponin values can be measured between 6 and 18 hours after the beginning of chest pain. The release of these bound proteins continues longer than the release of many other markers, and up to 14 days after acute myocardial infarction elevated troponin values can be detected $(10,22,60)$.

The question arises whether there is a difference in cardiac specificity between the cardiac subtypes of $T n T$ and $T n l(80,83)$. For $T n T$ false positive increases have been found in patients with renal insufficiency compared to Tnl (84 -86), and especially in chronic renal insufficiency (87). Compared to $\mathrm{TnT}$ a better cardiac specificity has been described for $\mathrm{Tnl}$ (37,88-91). It has to be established whether these differences reach clinical significance. Recently a second generation ELISA for TnT with substantially improved specificity for cardiac muscle damage has been developed (92). Tnl appears to be ideally suited for the detection of ischaemic myocardial injury in complex 
clinical situations, because of its high specificity. It indicates myocardial tissue damage in patients with unstable angina and is superior to CK.MB activity and mass in this respect (93).

A clinically important fact is that serum "evels of both troponins remain elevated up to at least two weeks after acute myocardial infarction. Even after serum levels of most other cardiac markers have normalised, the levells of cardiac TnT and cardiac Thl remain elevated, which makes it possible to detect cardiac cell death long after the clinical event took place $(8,36,60,94)$. Using this feature, continuing and minimal myocardial necrosis could be demonstrated in a subgroup of patients with unstable angina pectoris, and these patients proved to be at high risk of developing myocardial infarction $(7,8,10,22,95,96)$. Even minor cardiac cell damage during some days preceiding complaints in patients with unstable angina, can still be diagnosed when the patient presents at the emergency department $(97)$. Evidence has accumulated showing that the WHO criteria for acute myocardial infarction (24) allow the detection of only more extensive myocardial cell necrosis, but are of little value for detection of minor myocardial cell damage or for risk stratification of chest pain patients. The presence of admission TnT in patients with myocardial infarction defines a subgroup, particularly in those with ST-segment elevation, at increased risk of subsequent cardiac events and identifies a group that may benefit from alternative early management strategies (95).

In studies on release kinetics of TnT after acute myocardial infarction, a characteristic biphasic change in plasma concentration has been observed, especially in patients receiving thrombolytic therapy $(36,60,78,98)$. This biphasic change has been noted especially in patients with early reperfusion after thrombolytic therapy $(36,98: 104)$, and it has been suggested in several studies that TnT plasma time-concentration curves could thus be used for non-invasive assessment of coronary recanalisation (36,38-40,99-103). Intracellular compartmentation of TnT, i.e. the presence of both free cytosolic and structurally bound $\mathrm{Tn} T$, seems the primary cause of this biphasic release $(36,78,98)$. In cardiac tissue the free cytosolic TnT fraction is about $6 \%$ of the total TnT content in cardiac tissue $(36,60)$. However; these data were based on the measurement of TnT content in only three different cardiac tissue samples, obtained from heart donors (36). Structurally bound $\operatorname{Tn} T$ has to dissociate from the contractile myofibrillar structures, and is therefore more slowly released into plasma compared to the free cytosolic fraction, resulting in the biphasic time-concentration curve. In the isolated perfused rat heart it was demonstrated that prolonged ischaemia induced continuous liberation of cardiac TnT, most probably from disintegrating myofibres, whereas acute membrane damage caused almost exclusively leakage of functionally unbound $\mathrm{TnT}$ (78). Further knowledge on cardiac TnT content is lacking. Also, apart from the data presented in chapters 3 and 4 of this thesis, no studies on the quantification of TnT release after acute myocardiall infarction have been published.

Recently, De Winter et al. (1997) compared TinT, CK-MB mass and myoglobin (see below) for early diagmosis of acute myocardial infarction in a group of 309 patients and found that the sensitivity, specificity and negative and positive predictive value of a 
single measurement of a marker changes rapidly in the first hours after the onset of symptoms. For ruling out acute myocardial infarction, myoglobin appeared a better marker than $C K-M B_{\text {mass }}$ and $T n T$ from 3 until 6 hours, but the negative predictive value reached only $89 \%$ at 5 hours. In comparison the negative predictive value of CK-MB mass was $95 \%$ at 7 hours. Accuracy was not different in patients without diagnostic ECG's (128). Because of its slow release, compared to the free cytoplasmic alternatives $C K-M B_{\text {mass }}$ and myoglobin, $T n T$ was not suitable as an early marker for ruling out acute myocardial infarction $(9,31)$.

Commercial tests for the assay of Tnl were only introduced in the last few years and clinical experience with this marker is still limited. A biphasic plasma release curve was not found for Tnl, suggesting that there is no free cytosolic fraction present for this protein (105). It has been reported that perioperatively $\mathrm{Tnl}$ gives less false positive increases compared to $\mathrm{CK}-\mathrm{MB}{ }^{\left({ }^{89}\right)}$. Martins et al. found that cardiac Tnl (cTnl) has greater sensitivity than lactate dehydrogenase isoenzymes for delayed diagnosis of myocardial injury and recommend it as a test of choice in this setting (94).

\section{Fatty acid-binding protein}

Fatty acid-binding proteins $(14-15 \mathrm{kD})$ are cytosolic proteins involved in uptake, intracellular transport and metabolism of fatty acids. These proteins are found in all human tissues in which fatty acids are metabolised, such as heart, liver and intestines. In the heart, oxidation of long chain fatty acids supplies $60-90 \%$ of the energy required for electromechanical activity and other ATP-requiring processes $(119,120)$ and about $5 \%$ of the total cytosolic protein pool consists of FABP. Although often indicated as heart-type FABP this isoform is identical to the isoform in skeletal muscle, as is also the case for myoglobin. Of these two markers, however, the relative abundance of FABP in heart muscle, compared to the amount in skeletal muscle, is higher than of myoglobin, and a change in the plasma myoglobin/FABP ratio of its normal value of $20-70$ to about 5 has been used as an indicator for myocardial injury $(117,122,124,130)$.

Because of its small size FABP is a promising marker with regard to early diagnosis of acute myocardial infarction or early detection of reperfusion after trombolytic therapy (65.121.123). After onset of myocardial damage the plasma concentration of FABP is often already elevated within two hours, will reach its peak after about four hours and returns to normal levels within 16-24 hours. Although the changes in plasma concentrations of FABP and myoglobin generally run parallel, it has recently been shown that FABP performs better than myoglobin as an early marker of AMI (132.133). This can be explained by the low normal value of FABP of $1-4 \mathrm{ng} / \mathrm{ml}$, compared to a normal value of $20-70 \mathrm{ng} / \mathrm{m} /$ for myoglobin, allowing earlier detection of elevated plasma levels. In a study on the estimation of infarct size it was shown that cumulative FABP release, expressed as gram equivalents of healthy myocardium per litre plasma, yielded slightly higher infarct size than when estimated 
from HBDH-plasma curves (65). It has been shown that this finding is related to some degree of renal failure, with a decreased renal clearance of $F A B P$, in a significant subgroup of patients with AMI (66). At this moment FABP is not widely used, because in contrast to myoglobin, CK-MB mass , troponin $T$ or troponin $\mathrm{I}$, commercially available test kits for this marker have not yet found their way into clinical practice.

\section{Objectives of the present study}

The aim of our study is to contribute to improvement of diagnosis and treatment of patients with unstable angina and/or acute myocardial infarction by elucidation of quantative aspects of the use of new marker proteins. From the onset of their availability, cardiac marker proteins have been important in clinical practice both for diagnostic and prognostic purposes. This development started with the routine determination of the enzymatic activity of serum glutamate oxaloacetate transferase (SGOT, now indicated as AST) in the clinical laboratory in 1954 (70).

New developments in this field concern the study of cardiospecific proteins (troponins) after myocardial damage and the study of rapidly released small proteins (myoglobin, FABP). The designation 'minor myocardial damage' can be better defined now leading to improved differentiation between patients with AMI or with unstable angina pectoris. Determination of more specific and/or rapidly released markers is expected to have prognostic value in the latter group. However only few quantitative data on these newer markers have been reported, insufficient for clinical application. It is the objective of this study to contribute to this field. Special attention is given to the application of increasing knowledge on biochemical changes during and following the pathophysiological process of arterial occlusion and cardiac tissue necrosis.

The following aspects will be investigated:

- In order to translate the measurements of marker proteins in plasma or serum into quantitative information on myocardial damage, the tissue content and the distribution of these markers in cardiac human tissue must be known. Values as found in healthy hearts were studied in cardiac tissue samples obtained from patients who died from other causes than cardiac disease. In this way, the localisation of these substances in inferior/posterior or anterior/lateral regions, or epi-, mid-, of endocardial differences in protein content, can be obtained. For $\mathrm{LDH}, \mathrm{HBDH}, \mathrm{CK}$ and tropinin $\mathrm{T}$ these data are presented in Chapter two and for myoglobin, FABP and HBDH in Chapter four.

- Although the new cardiac specific protein TnT has proven to be highly valuable as a diagnostic marker, little is known about the quantitative aspects of $\mathrm{TnT}$ release. This is especially disturbing because this bound protein is only gradually liberated from the myofibrils and can be released only partially. Conclusions about the extent of damage based on this protein could thus be different from those based on other markers, such as the rapid and completely 
liberated cytosolic proteins. Also, the release of $\mathrm{TnT}$ could be different after coronary reperfusion, for instance, a larger fraction of cardiac TnT could then be released. Therefore the release of $T n T$ was quantitatively compared to the release of $\mathrm{HBDH}$ and $\mathrm{CK}$ (chapter 2) and this comparison was extended to reperfused and non-reperfused patients (chapter 3 ).

- Small cytosolic proteins like FABP and myoglobin reach plasma much faster than large ones like CK and HBDH. Also, the release of small proteins is terminated much earlier than the release of large ones. This implies that, after being liberated from the disrupted cardiomyocytes, the large marker proteins wil remain much longer in the potentially denaturating conditions of the ischaemic tissue than small ones. Increased recovery in plasma of small proteins, or of relatively stable proteins, could thus be expected. A comparison of small (FABP and myoglobin) and large (HBDH (stable) and CK (unstable)) (see ref. $24 \mathrm{Ch}$. 2) cytosolic markers was therefore made in chapter 5 .

- The clinical reliability of a certain marker does not only depend on its cardiac specificity and the completeness of its release after cardiac cell damage. We should also be certain that the concentration of that marker in the blood is not influenced by extracardial processes, such as changes in renal clearance of the markers. This aspect was studied by a comparison of markers that are eliminated from plasma by the liver with markers excreted by the kidneys. Also, the infuence of renal function on plasma levels of myoglobin or FABP in patients suffering acute myocardial infarction was studied (chapter 5). 


\section{Table I}

Parameters used to define diagnostic performance

\section{illness}

test

$\begin{array}{ll}+ & - \\ + & n_{1}\end{array}$

$n_{3} \quad n_{4}$

$n_{1}=$ number of all patients who scored positive on the test

$n_{2}=$ number of all patients who scored negative on the test

$n_{3}=$ number of unaffected patients who scored positive on the test

$n_{4}=$ number of unaffected patients who scored negative on the test

Parameters to be used for indicating the performance of the test: sensitivity $=100 . n_{1} /\left(n_{1}+n_{3}\right)=$ percentage of true pasitives specificity $=100 . n_{4} /\left(n_{2}+n_{4}\right)=$ percentage of true negatives

Parameters relevant to the clinician:

positive predictive value $=100 . n_{\|} /\left(n_{1}+n_{2}\right)=$ percentage of correct positive tests negative predictive value $=100 . n_{4} /\left(n_{3}+n_{4}\right)=$ percentage of correct negative tests

\section{Table 2}

\section{Diagnostic value of different parameters to detect reperfusion}

\section{sensitivity specificity}

Reperfusion arrhythmias

ST-segment reduction

Reduction of cardiac pain

Myoglobin

Myoglobin

Creatine kinase

Creatine kinase

$C K-M B$

CK-MB

Troponin T

Troponin T
$50 \%$

$76 \%$

$83 \%$

$\max$.

slope

max.

slope

max.

slope

max.

slope
$91 \%$

$94 \%$

$89 \%$

$87 \%$

$78 \%$

$85 \%$

$74 \%$

$80 \%$
$94 \%$

$7 \mid \frac{\%}{4}$

$41 \%$

$77 \%$

$88 \%$

$82 \%$

$7 \mid \%$

$65 \%$

$7 \mid \%$

$7 \mid \%$

$65 \%$ 


\section{Figure 4}

Troponin

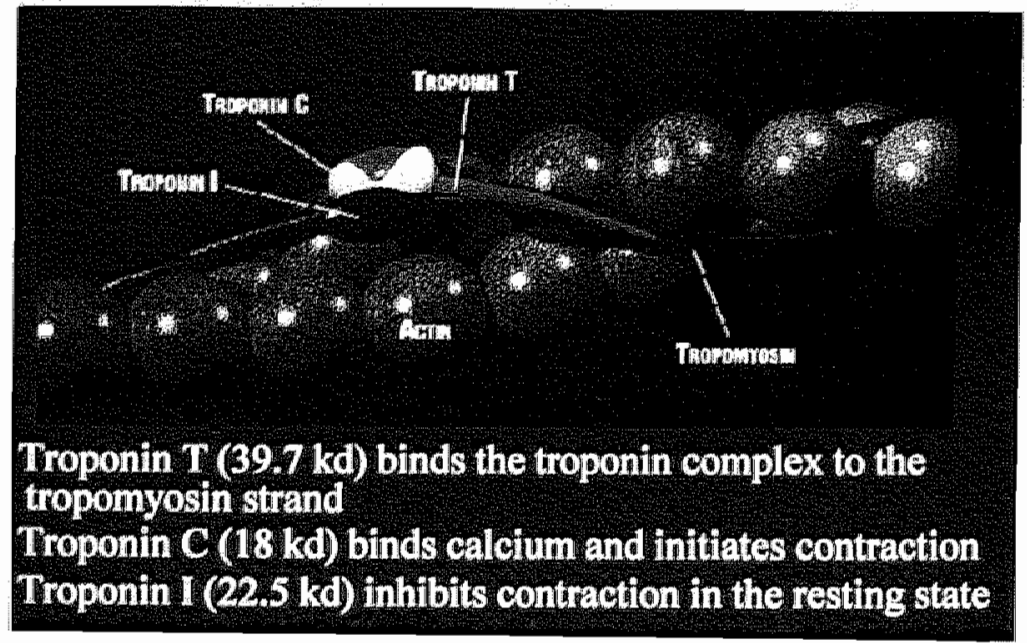




\section{References}

1. CBS. Statistisch jaarboek 1996: SDU uitgeverij, 1996

2. RIVM. Regionale gezondheidsprofielen. Leiden: Rijksinstituut voor volksgezondheid en milieuhygiene., 1992.

3. Pepine CJ. Prognostic markers in thrombolytic therapy: looking beyond mortality. Am J Cardiol 1996; 78: 24-7.

4 Braunwald E. Heart disease, A. Textbook of Cardiovascular Medicine, 1992; Saunders, Philadelphia.

5. Braunwald $E$. Unstable angina: a classification. Circulation 1989; $80: 410-4$.

6. Wierzbicki AS, Reynolds TM. Cardiac troponin $T$ in unstable angina. Troponin $T$ could be used to identify patients needing early treatment [letter]. Bmj 1996:313: 1330-1.

7. Kennedy RL. Cardiac troponin $T$ in unstable angina. Does measurement of troponin $T$ add to ability to stratify risk? [letter]. Bmj 1996; 313: 1330-1.

B. Apple FS, Wu AH, Valdes $\mathbb{R}$, Jr. Serum cardiac troponin $T$ concentrations in hospitalized patients without acute myocardial infarction. Scand J Clin Lab Invest 1996; 56:63-8.

9. De Winter RJ, Koster RW, Schotveld JH, Sturk A, van Straalen JP, Sanders GT. Prognostic value of troponin $T$, myoglobin, and $C K-M B$ mass in patients presenting with chest pain without acute myocardial infarction. Heart 1996; 75: 235-9.

10. Ohman EM, Amstrong PW, Christenson RH, Granger CB, Katus HA, Hamm CW, et al. Cardiac troponin $T$ levels for risk stratification in acute myocardial infarction. New Engl 」 Med 1996; 335: 1333-41.

11. Stark ME, Vacek JL. The initial electrocardiogram during admission for myocardial infarction. Arch Intern Med 1987; 147: 843-6.

12. Gibler WB, Lewis LM, Erb ER, Makens PK, Kaplan BC, Vaughn RH, et al. Ann Emerg Med $1990 ; 19: 1359-66$.

13. Gibler WB. Chestpain evaluation in the ED: Beyond triage (Editorial). Am J. Emerg. Med 1994; 12:121-2.

14. Conti C, Brawly R. Am Yearbook Cardiology 1973; 32: 745-50.

15. Mulcany R, Daly L. Natural history and prognosis in angina. Am Heart J 1985; 109: 753-8.

16. Botker HE, Ravkildie J. Sogaard P, Jorgensen PJ, Horder M. Thygesen K. Gradation of unstable angina based on a sensitive immunoassay for serum creatine kinase $\mathrm{MB}$. Br Heart J $1991 ; 65: 72-6$.

17. Ravkilde J, Hansen $A B$, Horder M, Jorgensen PJ, Thygesen K. Risk stratification in suspected acute myocardial infarction based on a sensitive immunoassay for serum treatine kinase isoenzyme MB. A 2.5-year follow-up study in 156 consecutive patients. Cardiology 1992; 80: $|43-5|$.

18. Pettersson $T$, Ohlsson $O$, Tryding $N$. Increased CKMB (mass concentration) in patients without traditional evidence of acute myocardial infarction. A risk indicator of coronary death. Eur Heart I 1992; 13:1387-92.

19. Apple FS, Voss E, Lund L, Preese L, Berger CR, Henry TD. Cardiac troponin, CK-MB and myoglobin for the early detection of acute myocardial infarction and monitoring of reperfusion following thrombolytic therapy. Clin Chim Acta 1995; 237: 59-66.

20. Wu AH. Feng YJ, Contois JH. Pervaiz S. Comparison of myoglobin, creatine kinase-MB, and cardiac troponin I for diagnosis of acute myocardial infarction. Ann Clin Lab Sci 1996; 26: 291-300.

21. Laurino JP, Bender EW, Kessimian $N$, Chang J, Pelletier T, Usategui M. Comparative sensitivities and specificities of the mass measurements of CK-MB2, CK-MB, and myoglobin for diagnosing acute myocaldial infarction. Clin Chem 1996; 42: 1454-9. 
22. Antmari EM. Tanasjjevic M). Thompson B, Schactman M, MeCabe CH, Cannon CP, et al. Cardiac-specific troponin I levels to predict the risk of mortality in patients with acute coronary insufficiency. New Engl I Med 1996; 335: 1342-9.

23. Wu AH, Feng Y], Contois JH, Azar R, Waters D. Prognostic value of cardiac troponin 1 in patients with chest pain [letter]. Clin Chem 1996; 42:651-2.

24. WHO. World Healch Organisation criteria for the diagnosis of acute myocardial infarction. Proposal for the multinational monitoring of trends and determinaints in cardiowascular disease. Geneva: Cardiowascular Disease Unit of WHO, 1981.

25. Rude RE, Poole WK, Muller JE, al e. Electrocardiographic and clinical criteria for recognition of acute myocardial infarction based on analysis of 3.697 patients. Am J Cardial 1983; 52 : 936-42.

26. Yusuf $S$, Pearson $M$, Sterry $H$. The entry ECG in early diagnosis and prognostic risk stratification of patients with suspected acute myocardial infarction. Eur Heart $\int 1984 ; 5$ : 690-6.

27. Wong SS. Strategic utilization of cardiac markers for the diagnosis of acute myocardial infarction. Ann Clin Lab Sci 1996; 26: $301-12$.

28. Apple FS. Acute myocardial infarction and coronary reperfusion. Serum cardiac markers for the 1990s (review). Am J Clin Pathol 1992; 97: 217-26.

29. Bahayana $V$. Henderson AR. Biochemical markers of myocardial damage, review. Clin Biochem 1995: 28: 1-19.

30. Bakker AJ. New biochemical markers in the early diagnosis of acute myocardial infarction. University of Amsterdam, 1994.

31. De Winter RJ. Biochemical and inflammatory markers of acute myocardial damage. Amsterdam. 1997.

32. De Wood MA, Amsterdam EA. Value and limitations of trombolytic therapy in ear acute myocardial infarction. Cardiology 1985; 72: 255-79.

33. Every NR, Parsons LS, Hlatky M. Martin JS. Weaver WD. A comparison of thrombolytic therapy with primary coronary angioplasty for acure myocardial infarction. Myocardial infarction triage and intervention investigators. New Engl J Med 1996; 335 (17): 1253-60.

34. Kircher B. Topol B], O'Neill WW, Pitt B. Prediction of infarct coronary artery recanalization after intravenous thrombolytic therapy. Am\Coll Cardiol $1987 ; 59: 513-5$.

35. Califf RM, O'Neill W, Stack RS, Aronson L, Mark DB, Mantell S, et al. Failure of simple clinical measurements to predict perfusion status after intravenous thrombolysis. Ann Interin Med 1988; 108: 658.62.

36. Katus HA, Remppis A, Scheffold T, Diederich KW, Kuebler WN. Intracellular compartmentation of cardiac troponin $T$ and its release kinetics in patients with reperfused and nonreperfused myocardial infarction. Am / Cardiol 1991; 67: 1360-7.

37. Keffer JH. Myocardial markers of injury. Evolution and insights. Am J Clin Pathol 1996: 105: 305-20.

38. Zabel M, Hohnloser SH, Koster W. Prinz M, Kasper W, Just H. Analysis of creatine kinase, $C K . M B$, myoglobin, and troponin $T$ time-activity curves for early assessment of corronary artery reperfusion after intravenous thrombolysis. Circulation 1993; 87; 1542-50.

39. Laperche T. Steg PG. Dehoux M. Benessiano J. Grollier G, Aliot E, et al. A study of biochemical markers of reperfusion early after thrombolysis for acute myocardial infarction. The PERM Study Group. Prospective Evaluation of Reperfusion Markers. Circulation 1995; 92: $2079-86$.

40. Abe $S_{n}$ Arima $S_{n}$ Yamashita T. Miyata $M_{n}$ Okino $H$. Toda $H$, et al. Early assessment of reperfusion therapy using cardiac troponin T. ॥ Am Coll Cardial 1994; 23: 1382-9.

41. Apple FS, Henry TD, Berger CR, Landt YA. Early monitoring of serum cardiac troponin I for 
assessment of coronary reperfusion following thrombolytic therapy [see comments]. Am] Clin Pathol 11996; 105: 6-10.

42. Van der Laarse A, Kerkhof PLM, Serruys PW, Hermens WT, Verheugt FWA, Bar FW, et al. Relation between infarct size and left ventricular performance assessed in patients with first acute myocardial infarction randomized to intracoronary or to conventional therapy. Am J Cardiol 1988; 61: $\mid 1-7$.

43. Anderson JL, Marshall HW, Askins JC, Lutz JR, Sorensen SG. A randomized trial of intravenous and intracoronary streptokinase in patients with acute myocardial infarction. Circulation 1984; 70: 606-18.

44. Simoons ML, Serruys PW, van den Brand M, Res J, Verheugt FWA, Krauss XH, et al. Early thrombolysis in acute myocardial infarction: Limitation of infarct size and improved survival. Am Coll Cardiol 1986; 7: 717-28.

45. Van de Werf F, Arnold AER. For the European Cooperative Study Group for recombinant tissue type plasminogen activator: intravenous tissue plasminogen activator and size of infarct, left ventricular function and survival in acute myocardial infarecion. $\mathrm{Br}$ Med J 1988; 297: 1374-9.

46. ISAMI. The ISAM Study Group: A prospective trial on intravenous streptokinase in acute myocardial infarction. New Engl J Med 1986; 314: ॥465-7\|.

47. Karagounis L. Sorensen SG, Menlowe RL. Moreno F. Andersen JL. Does thrombolysis in myocardial infarction (TIMI) perfusion grade 2 represent a mostly patent artery or a mostly occluded artery? enzymatic and electrocardiographic evidence for the TEAM-2 study. I Am Coll Cardiol 1992; 19: 1-10.

48. Roberts R. Enzymatic estimation of infaret size. Thrombolysis induced its demise: Will it now rekindle its renaissance? Circulation 1990; 81 : 707-10.

49. Willems GM, Visser MP, Krill MTA, Hermens. WT. Quantitative analysis of plasma emzyme levels based on simultaneous determination of different enzymes. Cardiovasc Res 1982; 16: |20-3|.

50. Visser MP, Krill MTA, Willems GM, Hermens WT. Selection of a suitable model for the plasma clearance and distribution of cardiac enzymes in the dog. Cardiovasc Res 1981: 15: $35-42$.

51. Van Kreel BK, Van der Veen FH. Willems GM, Hermens WT. Circulatory models in assessment of cardiac enzyme release in dogs. Am J Physiol 1993; (Heart Circ Vol 33): H747-H54.

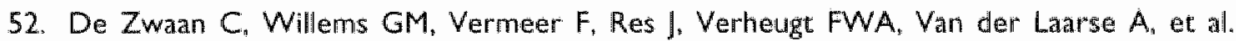
Enzyme tests in the evaluation of thrombolysis in acute myocardial infarction. Br Heart J 1988; 59: 175-83.

53. Van der Veen FH, Hermens WT, Willems GM. Schrijwers-van Schendel A, Mullers-Boumans $M L$, Reneman RS. Time course of cellular enzyme release in dog heart injury. Circ Res 1990; 67: 1257-66.

54. Clark GL, Robinson AK, Gnepp DR, Roberts R, Sobel BE. Effects of lymphatic transport of enzyme on plasima creatine kinase time-activity curves after myocardial infarction in dogs. Circ Res 1978; 43: 162-9.

55. Bleifelld W, Mathey $D$, Hanrath $P$, Buss $H$, Effert $S$. Infarct size estimated from serial creatine phosphokinase in relation to lefe ventricular dynamics. Circulation 1977; 55: 303-11.

56. Grande P. Hansen BF, Christiansen C. Naestoft J. Estimation of acute myocardial infarct size in men by serum CK-MB measurements. Circulation 1982: 65: 756-64.

57. Hackel DB, Reimer KA, Ideker RE, Mikat EM, Hartwell TD, Parker CB, et al. Comparison of enzymatic and anatomic estimates of myocardial infarct size in man. Circulation 1984; 70 : 824-35. 
58. Jansen DE, Corbett JR, Wolfe CL, Lewis SE, Gabliani G. Filipchuk N, er al. Quantification of myocardial infarctio: a comparison of single photon-mission computed tomography with pyrophosphate to serial plasma MB-creatine kinase measurements. Circulation 1985; 72: 327.33.

59. Morrison J, Coromilas J, Munsey D, Robbins $M_{*}$ Zema $M$. Chiaramida $S_{n}$ et al. Correlation of radionuclide estimates of myocardial infarction size and release of creatine kinase- $M B$ in man. Circulation 1980;62:277-87.

60. Kragten $J A_{;}$Hermens WT, Van Diejen-Visser MP. Cardiac troponin T release into plasma after acute myocardial infarction: only fractional recovery compared with enzymes. Ann Clin Biochem 1996; 33: 314-23.

61. Kragten JA, Hermens WT, Van Diejen-Visser MP. Cumulative troponin T release after acute myocardial infarction (AMI). Influence of reperfusion. Eur J Clin Chem Clin Biochem 1997; 35.

62. Groth T. Hakman M, Sylven C. Size estimation of acute myocardial infarction from serial serum myoglobir observations with due consideration of individuall differences in basic kinetics, Scan J Clin Lab Inwest 1984; 44: 65-78.

63. Groth $T$, Hakman M, Sylven C. Prediction of myocardial infarct size from early serum myoglobin observations. Scand J Clin Lab Invest 1987; 47: 599-603.

64. Grottum P. Sederholm M, Kjekshus JK. Quantitative and temporal relation between the release of myoglobin and creatine kinase and the evolution of vectorcardiographic changes during acute myocardial infarction in man. Cardiovasc Res 1987; $21: 652-9$.

65. Glatz JFC, Kleine AH, Van Nieuwenhoven FA, Hermens WT, Van Dieijen-Visser MP, Van der Vusse G]. Fatty-acid-binding protein as a plasma marker for the estimation of myocardial infarct size in humans. Br Heart J 1994; 71: | 35-40.

66. Wodzig KWH, Kragten JA, Hermens WT, Glatz JFC, Van Dieijen-Visser MP. Quantification of cardiac myoglobin and fatty acid-binding protein release after acute myocardial infarction. Eur J Clin Chem Clin Biochem $1997 ; 35$ (3): 191-8.

67. Little WC, Constantinescu M. Applegate. Can coronary angiography predict the site of a subsequent myocardial infarction in patients with mild to moderate coronary disease. Circulation 1988; 78: 1157-66.

68. LaDue JS, Wroblewski F, Karmen A. Serum glutamic oxaloacetic transaminase activity in human acute transmural myocardial infarction. Science 1954; 120: 497-9.

69. Karmen A, Wroblewski F, LaDue $\ S$. Transaminase activity in human blood. I Clin Invest 1954: 34: 126-33.

70. Wroblewsiki F, LaDue JS. Lactic dehydrogenase acrivity in blood. Proc Soc Exp Biol Med 1955; 90:210-3.

71. Dreyfus $\rfloor C_{i n}$ Schapira $G$. Resnais \. Scebat L. La creatine-kinase serique dans le diagnostique de l'infarctus myocardique. Rev Fr Clin Biol 1960; 5: 3:86-7.

72. Van der Veen KJ. Willebrands KF. Isoenzymes of creatine phosphokinase in tissue extracts and in nomal and pathological sera. Clin Chim Acta 1966; 13: 312-6.

73. Konttinen $A$. Sommer $H$. Determination of serum creatine kinase isoenzymes in myocardial infarction. Am J Cardiol 1972; 29: 817-20.

74. Roberts R, Gowda KS, Ludbrook PA, Sobel BE. Specificity of elevated serum MB creatine phosphokinase activity in the diagnosis of acute myocardial infarction. Aim J Cardiol 1975; 36: 433-7.

75. Van Dieijen-Visser MP, Kragten JA, Glatz JFC, Hermens WT. Clinical relevance of early markers for the diagnosis of acute myocardial infarction (AMI). Tijdschr Ned Ver Klin Chem 1993; 3: 140-4.

76. Farah CS, Reinach FC. The troponin complex and regulation of muscle contraction (Review). Faseb J 1995; 9: 755-67. 
77. Raggi A, Grand RJA, Moir AJG. Structure-function relationships in cardiac troponin T. Biochim Biophys Acta 1989; 997: 135-43.

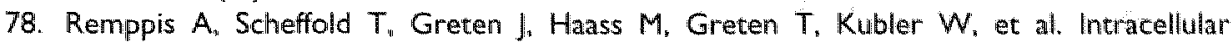
compartmentation of troponin $T$ : release kinetics after global ischemia and calcium paradox in the isolated perfused rat heart. J Mol Cell Cardiol 1995; 27: 793-803.

79. Katus HA, Remppis A, Looser S, Hallermeier K, Scheffold T, Kubler W. Enzyme linked immuno assay of cardiac troponin $T$ for the detection of acute myacardial infarction in patients. I Mol Cell Cardiol 1989; $21: 1349-53$.

80. Bodor GS. Porter S, Landt Y, Ladenson JH. Adams JEd, Bodor GS, et al. Development of monoclonal antibodies for an assay of cardiac troponin I and preliminary results in suspected cases of myocardial infarction. Cardiac troponin I a marker with high specificity for cardiac injury [see comments]. Clin Chem 1992; 38: 2203-14.

81. Bodor GS, Porterfield D, Voss EM, Smith S, Apple FS. Cardiac troponin I is not expressed in fetal and healthy or diseased adult human skeletal muscle tissue. Clin Chem 1995: 41: 1710 5 .

82. Zaninotto $M$, Altinier $S_{n}$ Lachin M, Carraro $P$, Plebani M. Fluoroenzymometric method to measure cardiac troponin I in sera of patients with myocardial infarction. Clin Chem 1996; 42: 1460-6.

83. Mair J, Puschendorf B, Michel G. Clinical significance of cardiac contractile proteins for the diagnosis of myocardial injury. Adw Clin Chem 1994; 31:63-98.

84. Hafner $G$. Thome Kromer B, Schaube J, Kupferwasser I, Ehrenthal W. Cummins P, et al. Cardiac troponins in serum in chronic renal faillure [letter] [see comments]. Clin Chem 1994: 40: 1790-1.

85. Li D. Jialal I, Keffer J. Greater frequency of increased cardlac troponin $T$ than increased cardiac troponin I in patients with chronic renal failure [letter]. Clin Chem 1996; 42: 1 14-5.

86. Braun SL, Baum H, Neumeier D. Vogt W. Troponin T and troponin I after coronary artery by pass grafting discordant results in patients with renal failure. Clin Chem 1996; 42: 781-3.

87. Frankel WL, Herold DA, Ziegler TW, Fitzgerald RL. Cardiac troponin $T$ is elevated in asymptomatic patients with chronic renal failure. Am J Clin Pathol 1996; \#06: 118-23.

88. Drown DJ. Cardiac Troponin li: a marker for cardiac injury occurring perioperatively. Prog Cardiovasc Nurs 1994; 9: 42.

89. Adams JE, Sicard GA, Allen BT, Bridwell KH, Lenke LG, Davila Roman VG, et al. Diagnosis of perioperative myocardial infarction with measurement of cardiac troponin I [see comments]. N Engl J Med 1994; 330:670-4.

90. Mair J, Genser $N$, Morandell D, Maier J, Mair $P$, Lechleitner $P$, et al. Cardiac troponin I in the diagnosis of myocardial injury and infarction. Clin Chim Acta 1996; 245: 19-38.

91. Adams JEr, Davila Roman WG, Bessey PQ. Blake DP, Ladenson JH, Jaffe AS. Improved detection of cardiac contusion with cardiac troponin I. Am Heart J 1996: 131:308-12.

92. Muller-Bardorf M" Hallermayer K, Schroder A, Ebert $C_{\text {" Borgya }} A_{4}$ Gerhardt $W$, et all Improved troponin T ELISA specific for cardiac troponin T isoform: assay development and anallytical and clinical walidation. Clin Chem 1997; 43: 458-66.

93. Bertinchant JP, Larue $C$, Pernel II Ledermann $B_{4}$ Fabbro Peray P. Beck L, et al. Release kinetics of serum cardiac troponin 1 in ischemic myocardial injury. Clin Biochem 1996; 29: $587-94$.

94. Martins JT, Li DJ, Baskin LB, Jialal I, Keffer \H. Comparison of cardiac troponin I and lactate dehydrogenase isoenzymes for the late diagnosis of myocardial imjury. Am I Clin Pathol 1996: 106: 705-8.

95. Stubbs P, Collinson P, Moseley D, Greenwood T, Noble M. Prognostic significance of admission troponin $T$ concentrations in patients with myocardial infarction. Circulation 1996: 94: 1291-7. 
96. Hamm CW. De Winter RJ, Koster RW, Sturk A, Sanders GT. New perspectives in therapy of unstable arigina. Value of myoglobin troponin $T_{\text {n }}$ and $C K-M B$ mass in ruling out an acute myocardial infarction in the emergency room. Herz 1996; 21: 37-43.

97. Gomez MA, Anderson $1 L$, Karagounis LA, Muhlestein JB, Mooers FB. An emergency department-based protocol for rapidly ruling out myocardial ischemia reduces hospital time and expense: results of a randomized study (ROMIO). J Am Coll Cardiol 1996; 28: 25-33.

98. Mair J. Artner-Dworzak $E_{n}$ Lechleitner P. Schmidt J. Wagner I, Dienstl F, et all. Cardiac troponin $T$ in diagnosis of acute myocardial infarction. Clin Chem 1991; 37: 845-52.

99. Mair J. Puschendorf B, Michel G. Clinical significance of cardiac contractile proteins for the diagnosis of myocardial injury. Adv Clin Chem 1994; $31: 63-98$.

100. Mair J, Wagner I, Jacob G. Lechleitmer P, Dienstl F, Puschendorf B, et al. Different time courses of cardiac contractile proteins after acute myocardiall infarction. Clin Chim Acta 1994: 231: 47-60.

101. Remppis A, Scheffold T, Karrer O, Zehelein J, Hamm C, Grunig E, et al. Assessment of reperfusion of the infarct zone after acute myocardial infarction by serial cardiac troponin $T$ measurements in serum. Br Heart $\int 1994: 7 \|: 242-8$.

102. Lavin $F$, Kane M. Forde A, Gannon F, Daly K. Comparison of five cardiac markers in the detection of repenfusion after thrombolysis in acute myocardial infarction. $\mathrm{Br}$ Heart J $1995 ; 73: 422-7$.

103. Apple FS, Sharkey SW, Henry TD. Early serum cardiac troponin I and T concentrations after successful thrombolysis for acute myocardial infarction. Clin Chem 1995; 41: 11978.

104. Gerhardt W, Katus H, Ravkilde J. Hamm C, Jorgensen PJ. Peheim E, et al. Serum troponin $T$ in suspected ischemic myocardial injury compared with mass and catalytic concentration of serum creatine kinase isoenzyme MB. Clin Chem 1991; 37: 1405-11.

105. Mair J, Thome Kromer B, Wagner I, Lechleitner P, Dienstl F, Puschendorf B, et al. Concentration time courses of troponin and myosin subunits after acute myocardial infarction. Coron Artery Dis 1994; 5: 865-72.

106. Hearse D. Molecular enzyme release. J Mol Med 1977; 2: 185-200.

107. Kagen L. Scheidt S, Butt A. Serum myoglobin in myocardial infarction: The "staccato phenomenon". Am J Med 1977; 62: 86-92.

108. Cairns J. Missirlis $E$, Walker $W$. Usefulness of serial determinations of myoglobin and creatinine kinase in serum compared for assessment of acute myocardial infarction. Clin Chem 1983; $29: 469-73$.

109. Delanghe JR, DeBuyzere ML. Cluyse LP. Thierens. HM, Clement DL. Acute myocardial infarction size and myoglobin release into serum. Eur $₫$ Clin Chem Clin Biochem 1992;30: 823-30.

1 10. Mair J. Artner-Dworzak E, Lechleiter P. Morass B, Smidt J, Wagner I, et al. Early diagnosis of acute myocardial infarction by a newly developed rapid immunoturbidimetric assay for myoglobin. Br Heart J 1992; 68: 462-8.

111. Kagen L. Myoglobin: methods and diagnostic uses. CRC Crit Rev Lab Sci | 978; 9: 273-302.

112. Ellis KA, Little T, Masud $Z_{n}$ Liberman HA, Morris DC, Klocke FJ. Early non-inwasive detection of successful reperfusion in patients with acute myocardial infarction.l. Circulation 1988; 78: 1352-7.

113. Katus HA, Diederich KW, Scheffold T, Uellner M. Schwarz F, Kubler W. Non-invasive assessment of infarct reperfusion: the prediccive power of time to peak value of myoglobin, CKMB and CK in serum. Eur Heart J 1988; 9: 619-24.

1 14. Yamashita T, Abe S, Arima S, Nomoto K, Miyata M, Maruyama I, et al. Myocardial infarct size can be estimated from serial plasma myoglobin measurements within 4 hours of reperfusion. Circulation 1993; 87: 1840-9. 
115. Hallgren $R$, Karlisson FA, Roxin LE, Venge $P$. Myoglobin turnover, influence of renal and extrarenal factors. J Lab Clin Med 1978; 91: 246-54.

116. Van Dieijen-Visser MP, Kragten JA, Glatz JFC, Hermens WT, Release kinetics of myoglobin, fatty-acid binding protein and troponin $T$ after acute myocardial infarction. Tijdschr Ned Ver Klin Chem 1993; 2: 100.

117. Kragten JA, Van Nieuwenhowen FA, Van Dieijen-Visser MP. Theunissen PHMH. Hermens WT, Glatz JFC. Distribution of myoglobin and fatty acid binding protein in human cardiac autopsies. Clin Chem 1996; 42: 337-8.

118. Kragten JA, Van Dieijen-Visser MP. Hermens WT. Diagnostiek en vroegdiagnostiek van het acuut myocardinfarct; de rol wan nieuwe biochemische merkers. Cardiogram 1996; 1: 3-5.

119. Veerkamp $\| H$, Peeters RA, Maatman RGHJ. Structural and functional features of different types of cytoplasmic farty acid binding proteins. Biochem Biophys Acta 199|: 1081: 1-24.

120. Glatz JFC, Van der Vusse GJ. Cellullar fatty acid binding proteins: Current concepts and future directions. Mol Cell Biochem 1990; 98: 237-51.

121. Tanalka T, Hirota $Y$, Sohmiya KI, Nishimura $S$, Kawamura K. Serum and urinary heart fatty acid binding protein in acute myocardial infarction. Clin Biochem 1991; 24: 195-201.

122. Van Nieuwenhoven FA, Kleine AH, Wodzig KWH, Hermens WT, Kragten HA, Maessen JG. et al. Discrimination between myocardial and skeletal muscle injury by assessment of the plasma ratio of myoglobin over fatty acid-binding protein. Circulation 1995; 92: 2848-54.

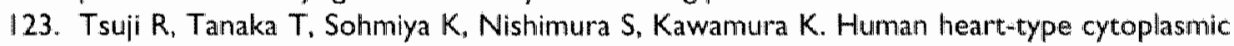
fatty acid-binding protein as an indicator of acute myocardial infarction. Int \Cardiol 1993 ; 41: 209-17.

124. Yoshimoto K. Tanaka T, Somiya K, Tsuji R, Okamoto F. Kawamura K, et al. Human hearttype cytoplasmic fatty acid-binding protein as an indicator of acute myocardial infarction. Heart Vessels 1995; 10: 304-9.

125. Sobel BE, Shell WE. Serum enzyme determinations in the diagnosis and assessment of myocardial infarction. Circulation 1992; 45: 471-82.

126. Puleo PR, Guadagno PA. Roberts $R$ Scheel MV. Marian AJ" Churchill D, et al. Early diagnosis of acute myacardial infarction based on assay subforms of creatine kinase-MB. Circulation 1990; 82: 759-64.

127. Seo H. Miyazaki S, Furuno T, Nonogi H. Haze K, Hiramori K. Creatine kinase-MB protein mass is a better indicator for the assessment of acute myocardial infarction in the lower range of creatine kinase level. Jpn Heart J 1993; 34: 7|7-27.

128. Kontos MC, Anderson FP, Hanbury CM, Roberts CS, Miller WG, Jesse RL. Use of the combination of myoglobin and CK-MB mass for the rapid diagnosis of acute myocardial infarction. Am J Emerg Med 1997; 15: 14-9.

129. Brown CS, Bertolet BD. Cardiac troponin. See ya later, CK! [editorial; comment]. Chest 1997: 1 |1 : :2-4.

130. Glatz JFC, Van der Vusse GJ. Cellulair fatty acid binding proteins: their function and plyysiological significance. Prog. Lipid Res 1996; 35, no 3: 243-82.

131. Van der Veen FH, Visse, R, Willems GM. Kop-Klaassen B, Hermens WTh. Myocardial enzyme depletion in infarcted human hearts: infarct size and equivalent tissue mass. Cardiovascular research; 1988; 22:611-9.

132 Ishi J, Wang, JH, Naruse $H$, Taga S, Kinoshita M, Kurokawa H, Iwase M, Kondo T, Nomura M. Nagamura $Y$, Watanabe $Y$, Hishida $H$, Tanaka $T$, Kawamura K. Serum concentrations of myoglabin vs. heart-type cytoplasmic fatty acid-binding protein in early detection of acute myocardial infarction. Clin. Chem. 1997; 43: 1372-8.

133 Glatz JFC. Haastrup B, Hermens WTh, De Zwaan C, Barker J, Mcneil C]. Adlains P. Luscher M Ravkilde I. Thygesen K, Kristensen S, Horder M, for the EUROCARDI Study Group. Fatty 
acid-binding protein and the early detection of acute myocardial infarction: The EURO. CARDI Multicenter Trial (abstract). Circulation, in press.

134 Moss DW, Henderson AR, Kachmar JF, Enzymes. in:Tietz N.W., ed. Fundamentals of Colinical Chemistry. Philadelphia: W.B. Saunders Company, 987: 379-385. 
Chapter 2

Quantification of cardiac troponin T release into plasma after acute myocardial infarction. Only fractional recovery compared with enzymes

Johannes A. Kragten, Wim Th. Hermens and Marja P. van Dieijen-Visser

Ann. Clin. Biochem. 1996; 33// I4/PG I-10 


\section{Summary}

After acute myocardial infarction cardiac enzymes and proteins are released into plasma and are used as biochemical markers of cardiac muscle injury. We studied the completeness of the release of troponin $T$, a cardiac protein that is largely bound to myofibrillar structures and compared it with the release of cytoplasmic cardiac enzymes in 22 patients with acute myocardial infarction, who were treated with thrombolytic therapy.

Creatine kinase (CK) (EC 2.7.3.2), hydroxybutyrate dehydrogenase (HBDH), lactate dehydrogenase (LDH) (EC I.I.I.27) and troponin T were assayed serially in plasma samples obtained frequently and for at least 168 hours after the start of thrombolytic therapy. Cumulative release of enzymes and troponin $T$ in plasma was calculated by using a two-compartment model for circulating proteins. In order to express the cumulative plasma releases in gram equivalents $(\mathrm{g}$-eq) healthy myocardium per litre plasma (infarct size), we determined HBDH, LDH and total troponin $T$ contents per gram wet weight of tissue in 17 human hearts obtained postmortem from patients who died from non-cardiac causes. Mean (SD) tissue contents per gram wet weight of, respectively, $156 \pm 25 \mathrm{U} / g \mathrm{HBDH}, 385 \pm 59 \mathrm{U} / \mathrm{g} \mathrm{LDH}$ and $234 \pm 65$ $\mu g / g$ troponin $T$ were found.

For the cardiac enzymes CK, HBDH and LDH the mean (SEM, $n=22$ ) total release over 72 hours was, respectively, $5.9 \pm 1.5,5.9 \pm 1.6$ and $6.1 \pm 1.7 \mathrm{~g}$-eq. There was no further increase after 72 hours and the differences between enzymes were not significant. The mean (SEM) cumulative troponin $T$ release, expressed in gram equivalents of myocardium per litre of plasma was only $0.30 \pm 0.09 \mathrm{~g}$-eq after 72 hours and $0.51 \pm 0.16 \mathrm{~g}$-eq after 168 hours. After 72 hours total recovery of troponin $T$ in g-eq was only $5 \%$ and after 168 hours only $8.5 \%$ of the total recovery of cytoplasmic cardiac enzymes after 72 hours.

Cumulative troponin T release after 72 hours and after 168 hours correlates well with infarct size, estimated from cumulative cytoplasmic enzyme release. However, quantification of infarct size should preferably be performed from plasma release curves of cytoplasmic cardiac enzymes or proteins in order to prevent underestimation of infarct size, caused by incomplete release of the non-cytoplasmic proteins. 


\section{Introduction}

Enzymatic assessment of the extent of ischaemic myocardial injury has become normal clinical practice and has been applied successfully in the evaluation of thrombolytic therapy after acute myocardial infarction (AMI)(1-6). These studies demonstrated that the favourable effects of such therapy, namely preservation of myocardial function and reduced mortality, can be explained by limitation of infarct size and this has stimulated interest in the quantitative interpretation of enzymatic data and in the methodological aspects of such analysis $(7,8,9)$. In order to allow comparison of the cumulative release of different cardiac enzymes and proteins, total enzyme or protein release per litre of plasma is divided by the enzyme or protein content per gram wet weight of healthy cardiac tissue, so that myocardial injury can be expressed in gram equivalents ( $g$-eq) of healthy heart muscle per litre plasma (infarct size) (8.9). In this way it has been demonstrated that different cardiac enzymes such as creatine kinase (CK) and $\alpha$-hydroxybutyrate dehydrogenase $(\mathrm{HBDH})$ produce approximately similar estimates of infarct size in g-eq of heart muscle per litre of plasma (10).

Until now, no studies have been published on the quantification of troponin $T$ release after acute myocardial infarction. In studies on the kinetics of troponin $T$ release after acute myocardial infarction, a characteristic biphasic change in plasma concentration is observed, especially in patients receiving thrombolytic therapy $(11.12 .13)$. It has been suggested that intracellular compartmentation of troponin T, i.e. the presence of both free cytosolic and structurally bound troponin $T$, is the primary cause of this biphasic troponin $T$ release into plasma $(11,12)$. Structurally bound troponin $T$ has to be dissociated from the contractile myofibrillar structures before it can be released into the circulation. Therefore, earlier release of the free cytosolic fraction is to be expected. Katus (11) found a free cytosolic fraction of $6 \%$. These data were based on measurement of troponin $T$ content in only three different cardiac tissue samples, obtained from healthy donor organs. Further knowledge on cardiac troponin T content is lacking, but is of special importance in studies on quantification of myocardial infarction from troponin $T$ concentrations.

Therefore we examined the enzyme ( $\mathrm{LDH}$ and $\mathrm{HBDH})$ and total troponin $T$ content of cardiac tissue obtained at autopsy. To allow comparison with the literature both LDH and HBDH were determined. Moreover, cumulative release of troponin T was estimated from time-concentration plasma curves measured in patients with acute myocardial infarction, receiving thrombolytic therapy and whose blood was sampled at least 168 hours after the onset of symptoms. The cumulative release into plasma is expressed in g-eq tissue per litre plasma and compared with cumulative release of the cardiac enzymes $C K, H B D H$ (or $L D H$ ) in the same patients. 


\section{Patients and methods}

\section{Patients}

Patients ( 16 men and 6 women) presented at the Department of Cardiology of the Hospital De Wever \& Gregorius in Heerlen, with chest pain and ST segment elevation typical of acute myocardial infarction within 6 hours after the onset of symptoms, were treated with thrombolytic therapy. First $160 \mathrm{mg}$ of aspirin was given (unless already given by general practitioner or ambulance nurses), followed by thrombolytic therapy which consisted of 1.5 million units of streptokinase, given by infusion in 40 minutes. Four hours after starting thrombolytic therapy heparin was given, 12500 units subcutaneous, every 12 hours, during 5 days. All procedures followed were approved by the Medical Ethical Committee of the Hospital.

All patients included in the study had given informed consent and their mean age was $60 \pm 8.5$ years (mean SD, median 60 and range 39-78 years). The mean treatment delay was $2.3 \pm 1.3$ hours after onset of complaints (mean SD, median 1.8 and range 0.7-5.3 hours). Patients with increased risk of bleeding, previous coronary bypass surgery or $\mathrm{Q}$-wave infarction in the same location, severe hepatic or renal disease, or inability to give informed consent were excluded from the study.

Venous blood samples of $10 \mathrm{ml}$ were obtained just before starting thrombolytic therapy and I, 2, 3, 4, 5, 6, 8, 10, 14, 18, 22, 28, 34, 46, 58, 70, 82, 94, $118,142,166$ hours later. Exact sampling times were recorded and expressed as time after the onset of symptoms. Most samples were taken from indwelling catheters and care was taken to prevent haemolysis. Contamination with infused solutions was prevented by using a second catheter for infusion purposes. Blood was collected in pre-distributed and labelled tubes, containing dry heparin to prevent clotting and was taken to the laboratory immediately. Plasma samples, obtained after routine centrifugation, were stored at $-70^{\circ} \mathrm{C}$ until analysis.

\section{Enzyme and troponin $T$ assays}

Activities of the enzymes $\mathrm{CK}, \mathrm{HBDH}$ and $\mathrm{LDH}$ were measured spectrophotornetrically at $37 \circ \mathrm{C}$ using a centrifugal analyser (Cobas Bio System, HoffmannLa Roche, Basel, Switzerland). Commercially available test kits were used for CK-Nacetylcysteine (International Federation of Clinical Chemistry recommendation, Unimate 3 Roche, art No 073647 3), LDH (Societé Française Biologie Clinique recommendation, using pyruvate as a substrate, Unimate 3 Roche, art No 073657 0) and $\mathrm{HBDH}$ (Deutsche Gesellschaft für Klinische Chemie recommendation, optimized test from Boehringer, art No. I 442 589). The HBDH test is based on preferential catalytic activity of the myocardial isoforms $\mathrm{LDH}_{1}$ and $\mathrm{LDH}_{2}$ of lactate dehydrogenase in the conversion of $\alpha$-ketobutyrate. Activities were expressed in micromoles of substrate converted per minute $(U)$, either per litre of plasma $(U / L)$ or per gram wet 
weight of tissue $(\mathrm{U} / \mathrm{g}$ ww). Temperature correction coefficients were determined to allow comparison with data in the literature, that are mainly based on enzyme measurements at $25^{\circ} \mathrm{C}$. By measuring $\mathrm{CK}, \mathrm{HBDH}$ and $\mathrm{LDH}$ in 15 serum samples both at $25^{\circ} \mathrm{C}$ and at $37 \circ \mathrm{C}$ temperature correction factors for conversion of results from $25 \circ \mathrm{C}$ to $37 \circ \mathrm{C}$ of, respectively, $2.5,1.3$ and 2.1 were established.

Troponin $T$ was measured using the troponin $T$ immunoassay from Boehringer Mannheim (14). The assay was carried out in coated tubes, using the Boehringer Mannheim ES22 photometer.

\section{Autopsies}

Autopsies were done in the Department of Clinical Pathology of the Hospital De Wever \& Gregorius in Heerlen, within 24 hours after death from non-cardiac causes. Data on autopsy delay, heart weight and age of the patients at time of death are presented in Table I. About $4 \mathrm{~cm}$ from the apex a transmural tissue sample of about $2 \mathrm{gram}$ was cut from the anterior wall of the left ventricle, bordering the septum.

\section{Enzyme content per gram wet weight of myocardium}

Epicardial fat was removed from the tissue and, after gentle blotting to remove adhering moisture, an approximately $0.5 \mathrm{~g}$ transmural sample of the left ventricle was taken and weighed.. Each sample was homogenized separately. (Ultraturrax, Janke and Kunkel, type 18-10) and sonicated (Sonorex Baudelin, type RK $102 \mathrm{H}, 120-240 \mathrm{~W}, 35$ $\mathrm{kHz}$ ). Homogenization, in 10 bursts and sonification, in five $60 \mathrm{~s}$ bursts, were performed in tubes kept on ice and containing $9.5 \mathrm{ml}$ of a $4 \%$ pasteurized plasma protein solution (The Netherlands Red Cross Blood Transfusion Service, Amsterdam, The Netherlands). The suspension was centrifuged at $2000 \times \mathrm{g}$ for 15 minutes and the supernatant was immediately stored at $-70^{\circ} \mathrm{C}$ until enzyme analysis (15), In healthy dog hearts this procedure resulted in $10-12 \%$ overall variation in enzyme content, including 4-6\% intra-assay scatter for cardiac enzymes (15).

\section{Troponin T content per gram wet weight of myocardium}

For the determination of total troponin $T$ content the method described by Katus was used (11). A transmural sample was weighed and $0.5 \mathrm{gram}$ was homogenized in 10 volumes of prechilled low-ionic strength buffer $(0.05 \mathrm{M}$ tris hydrochloride, $\mathrm{pH}$ concentration $7.0,7.0 \mathrm{mM}$ ethylene dinitrilotetraacetic acid, $0.5 \mathrm{mM}$ dithiotreitol), using 5 bursts of 15 duration with an Ultra Turrax homogenizer. 
The homogenate was then stirred for I hour at $4 \circ \mathrm{C}$. Thereafter, insoluble molecules were sedimented by ultracentrifugation $(100.000 \times g)$ for $\mid$ hour. This extraction step for soluble cytosolic molecules was repeated twice. The resulting supernatants were saved for measurement of cytosolic troponin $T$ concentrations. Troponin $T$ was extracted from the insoluble precipitated myofibrils by homogenization of the precipitate in $\mathrm{pH} 7.0$ buffer containing $0.4 \mathrm{M}$ potassium chloride, $0.1 \mathrm{M}$ potassium dihydrogen phosphate, $0.05 \mathrm{M}$ potassium monohydrogen phosphate, $0.04 \mathrm{M}$ sodium pyrophosphate, $0.01 \mathrm{M}$ magnesium chloride, and stirring for I hour at $4 \circ \mathrm{C}$. The solubilized troponin $T$ complex was separated from insoluble actomyosin and cellular debris by centrifugation at $20.000 \mathrm{~g}$ for I hour. Fractions for troponin $T$ analysis were frozen at $-70{ }^{\circ} \mathrm{C}$ until analysis of the total troponin $T$ content which was expressed as $20 \mu \mathrm{g} / \mathrm{g}$ wet weight of tissue.

\section{Table I}

\section{Troponin $\mathrm{T}$, hydroxybutyrate dehydrogenase (HBDH) and lactate dehydrogenease (LDH) contents of human hearts}

\begin{tabular}{|c|c|c|c|c|c|c|c|c|}
\hline Patient & $\begin{array}{l}\text { Age } \\
\text { (years) }\end{array}$ & Sex & Cause of deach & $\begin{array}{l}\text { Heart } \\
\text { weight } \\
\text { (g) }\end{array}$ & $\begin{array}{l}\text { Autopsy } \\
\text { delay } \\
\text { (h) }\end{array}$ & $\begin{array}{l}\text { troponin } \mathrm{T} \\
\text { (uglg wet } \\
\text { weighc) }\end{array}$ & $\begin{array}{l}\text { HBDH } \\
\text { U/g wet } \\
\text { weight) }\end{array}$ & $\begin{array}{l}\text { LDH } \\
\text { Uig wet. } \\
\text { weighti) }\end{array}$ \\
\hline 1 & 80 & $F$ & Hypovolaemia & 260 & 24 & 180 & 152 & 387 \\
\hline 2 & 74 & $M$ & Pneumonia & 380 & 4 & 271 & 181 & 454 \\
\hline 3 & 55 & $M$ & Cerebrovascular accident & 850 & 24 & 167 & 103 & 264 \\
\hline 4 & 76 & $\mathbb{F}$ & Carcinoma & 325 & 5 & 221 & 152 & 388 \\
\hline 5 & 74 & $M$ & Carcinoma & 370 & 7 & 130 & 127 & 328 \\
\hline 6 & 70 & $M$ & Fibrosis of the lungs & 350 & 24 & 150 & 145 & 345 \\
\hline 7 & 86 & M & Heart failure & 740 & 8 & 261 & 159 & 388 \\
\hline 8 & 74 & $F$ & Lung emphysema & 280 & 16 & 336 & 202 & 503 \\
\hline 9 & 20 & $F$ & Cerebrovascular accidene & 330 & 21 & 161 & 132 & 324 \\
\hline 10 & 75 & $M$ & Sepsis & 430 & 22 & 266 & 165 & 410 \\
\hline 11 & 36 & $\mathrm{~F}$ & Cenebrovascular accident & 310 & 15 & 346 & 180 & 414 \\
\hline 12 & 83 & $\mathrm{~F}$ & Lung emphysema & 215 & 12 & 271 & $\| 83$ & 449 \\
\hline 13 & 77 & $M$ & Penumonia & 370 & 5 & 199 & 159 & 386 \\
\hline 14 & 90 & $\mathrm{~F}$ & Carcinoma & 380 & 3 & 261 & 129 & 322 \\
\hline 15 & 54 & $F$ & Carcinona & 300 & 24 & 223 & 174 & 428 \\
\hline 16 & 57 & $\mathrm{~F}$ & Carcinoma & 500 & 8 & $3 \|$ & 140 & 338 \\
\hline 17 & 74 & M & Lung emphysemea & 300 & 7 & 223 & 170 & 415 \\
\hline Mean & 68 & & & 394 & 14 & 234 & $\| 56$ & 385 \\
\hline Median & 74 & & & 3.50 & 12 & 223 & 159 & 388 \\
\hline SD & 13 & & & 166 & $8 \cdot 2$ & $64 \cdot 5$ & $25 * 0$ & $59 \cdot 4$ \\
\hline SEM & $4 \cdot 4$ & & & 40 & $2 \cdot 0$ & $15 \cdot 6$ & 6.1 & $\| 4 \cdot 4$ \\
\hline CW $(\%)$ & 27 & & & 42 & 61 & $27 \cdot 6$ & 16.0 & $\| 5 * 4$ \\
\hline
\end{tabular}

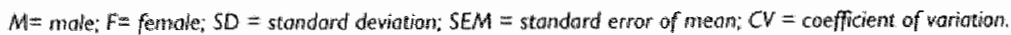




\section{Calculation of cumulative release of enzymes and troponin $T$ into plasma}

$Q(t)$, the cumulative release of enzyme activity and troponin $T$ concentration per litre of plasma from the onset of acute myocardial infarction $(t=0)$ up to time $t$ was calculated with the following expression for a two-compartment model:

$$
Q(t)=C(t)+T E R \int_{0} t \exp [-E R R(t-\tau)] C(\tau) d \tau+F C R \int_{0} t r C(\tau) d \tau
$$

The three terms are the enzyme activity in plasma, the extravasated activity and the activity eliminated from plasma, all three expressed per litre of plasma. The parameters TER, ERR and FCR represent the fractional rate constants for transcapillary escape, extravascular return and catabolism of activity "respectively. This two-compartment model has been validated in the dog ${ }^{(16,18)}$ and parameter values estimated in man are (19):

$$
\begin{aligned}
& \mathrm{FCR}_{\text {HBDH or LDH }}=0.015 \mathrm{~h}^{-1}, \mathrm{FCR}_{\mathrm{CK}}=0.20 \mathrm{~h}^{-1}, \\
& T E R=0.014 \mathrm{~h}^{-1} \text { and } \mathrm{ERR}=0.018 \mathrm{~h}^{-1} .
\end{aligned}
$$

For troponin $\mathrm{T}$, a value of $\mathrm{FCR}=0.11 \pm 0.05 \mathrm{~h}^{-1}$ [mean (SD)] was obtained from a fitting procedure on troponin $\mathrm{T}$ and $\mathrm{HBDH}$ plasma curves, as described by Willems (19). The procedure is based on simultaneous release of the two proteins from the same (cytoplasmic) compartment, which means that the released troponin T should be the free cytosolic fraction. Therefore, fitting was limited to the first 24 hours after first symptoms and it was verified that fitting over 18 or 30 hours gave similar results, which indicates that the release of fibrillar troponin $T$ remains negligible during this period. The mean obtained value of $F C R_{\text {troponin } T}=0.11 \mathrm{~h}^{-1}$ was used in the calculations.

Plasma enzyme activities measured at time $t, C(t)$, were corrected by subtraction of the normal steady-state activities $C_{s}$. If the first plasma sample was obtained within 4 hours after the onset of symptoms, the corresponding enzyme activities were used for $C_{s}$. In the remaining three cases, fixed mean values of $100 \mathrm{U} / \mathrm{L}$, $112 \mathrm{U} / \mathrm{L}, 260 \mathrm{U} / \mathrm{L}$, and $0 \mu \mathrm{g} / \mathrm{L}$ were used for $\mathrm{CK}, \mathrm{HBDH}, \mathrm{LDH}$ and troponin $\mathrm{T}$. respectively.

\section{Expression of infarct size in g-eq of tissue per litre of plasma}

In order to express myocardial injury in g-eq of healthy myocardium per litre of plasma, the cumulative release of enzymes per litre of plasma was divided by the respective enzyme content per gram of wet weight of cardiac tissue. For CK the enzyme content per gram wet weight of tissue was obtained from the literature. $\mathrm{CK}$ content has to be determined in fresh myocardium obtained at cardiosurgery, 
because $C K$ is decreased in samples obtained at autopsy (11). Therefore, a CKcontent of $865 \mathrm{U} / \mathrm{g}$, wet weight measured in fresh cardiac biopsies obtained after cardiosurgery was used (20). The value was converted to an equivalent value at $37 \circ \mathrm{C}$, by multiplication by 2.5 , giving a CK content of $2163 \mathrm{U} / g$ wet weight. $\mathrm{LDH}$ and $\mathrm{HBDH}$ are not susceptible to autolysis and enzyme content in samples obtained at autopsy is comparable with the enzyme content in samples of fresh myocardial tissue (20). $\mathrm{LDH}$ and $\mathrm{HBDH}$ content were determined in the same 17 hearts obtained at autopsy, used for determination of troponin $T$ content.

\section{Statistical analysis}

The release curves for proteins into plasma are presented as means with standard error of the mean (SEM)

\section{Results}

\section{Mean plasma $\mathrm{CK}$ and HBDH activity and troponin T concentration}

Mean plasma $\mathrm{CK}$ and $\mathrm{HBDH}$ activity and troponin $\mathrm{T}$ concentration as a function of time are shown in Fig. I. The large difference in time course of CK and $\mathrm{HBDH}$ does not reflect earlier release of $\mathrm{CK}$ or delayed release of $\mathrm{HBDH}$, but is caused by the difference in enzyme elimination rates from plasma: for CK $20 \%$ of the activity in plasma is eliminated per hour, whereas this figure is only $1.5 \%$ for $\mathrm{HBDH}$ and also for $L D H\left(F C R_{C K}=0.20 \mathrm{~h}^{-1}\right.$ vs $\mathrm{FCR}_{\mathrm{HBDH}}$ or $\left.L D H=0.015 \mathrm{~h}^{-1}\right)$. The biphasic troponin T curve clearly indicates a second source of release, starting about 40 hours after the onset of symptoms. 
Figure I

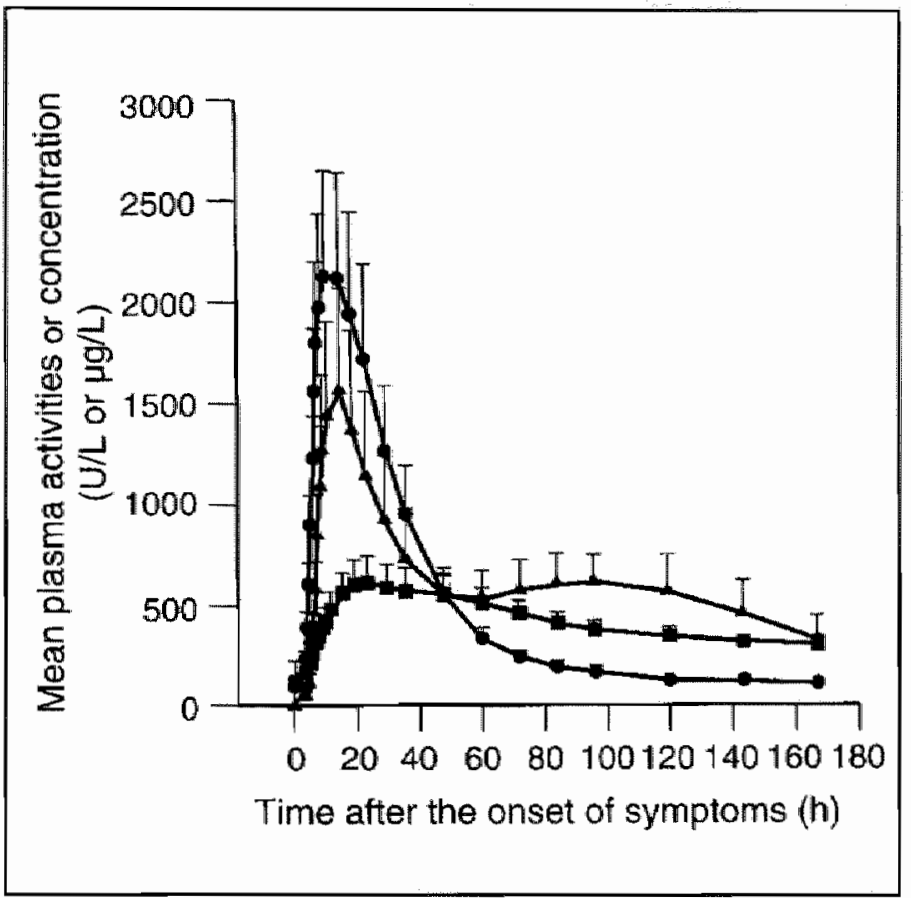

Mean plasma concentrations of creatine kinase (CK) and

hydroxybutyrate dehydrogenase (HBDH) expressed in U/L and

traponin $T \times 100$ in microgram per litre, in 22 patients.

Upper standard errar of meam (SEM) is indicated.

- $=$ CK $(U / L)$ :

$=\mathrm{HBDH}(U / \mathrm{L})$

$\mathbf{A}=\operatorname{troponin} T \times 100(\mu \mathrm{H} / \mathrm{L})$ 


\section{Figure 2}

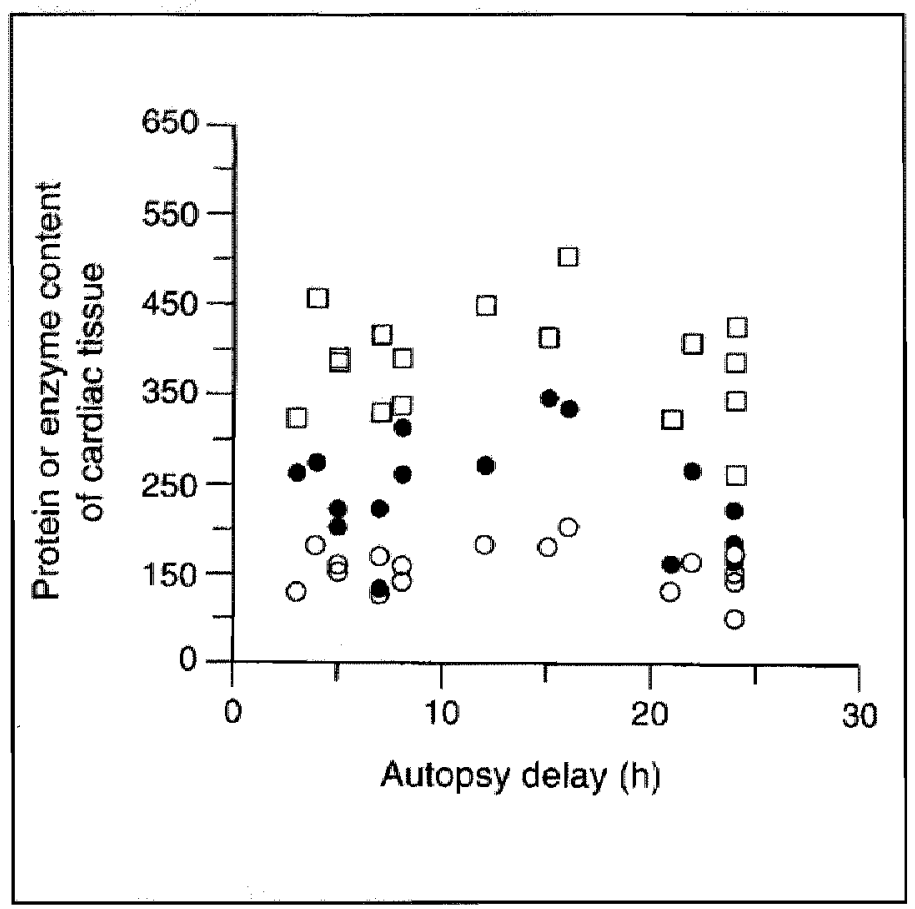

Troponin T, hydroxybutyrate dehydrogenase $(\mathrm{HBDH})$ and lactate dehydrogenose (LDH) content per gram wet weight of tissue related to the autopsy delay, i.e. effect of autolysis. $=$ tropanin $T(\mu \mathrm{g} / \mathrm{g})$;

$\mathrm{O}=\mathrm{HBDH}(\mathrm{U} / \mathrm{g})$;

$\square=L D H(U / g)$ 


\section{Figure 3}

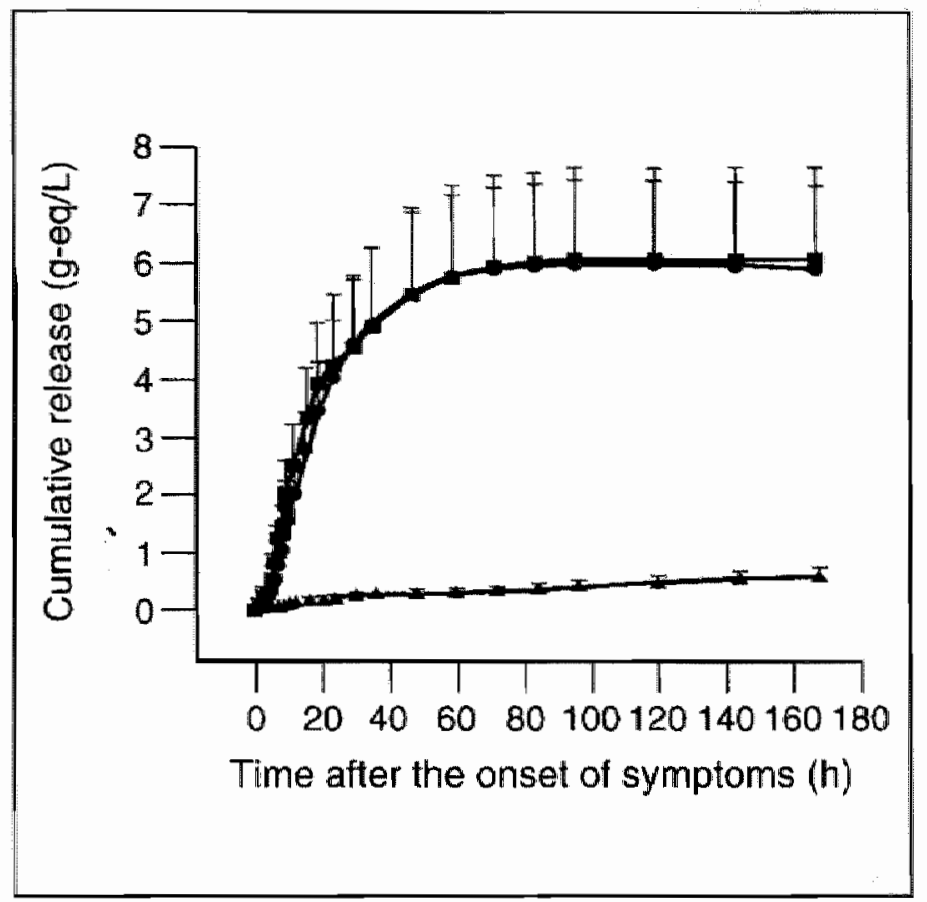

Mean cumulative release of creatine kinase (CK), hydroxybutyrate dehydrogenase (HBDH) and troponin $T$ at different times ofter the onset of symptoms, expressed in gram-equivalents ( $\mathrm{g}$-eq) of myocardium per litre of plasma, in 22 patients.

Upper standard error of mean (SEM) is indicated.
$=C K$
$=\mathrm{HBDH}$
$\mathbf{A}=$ troponin $T$ 
Figure $4 a, b, c$
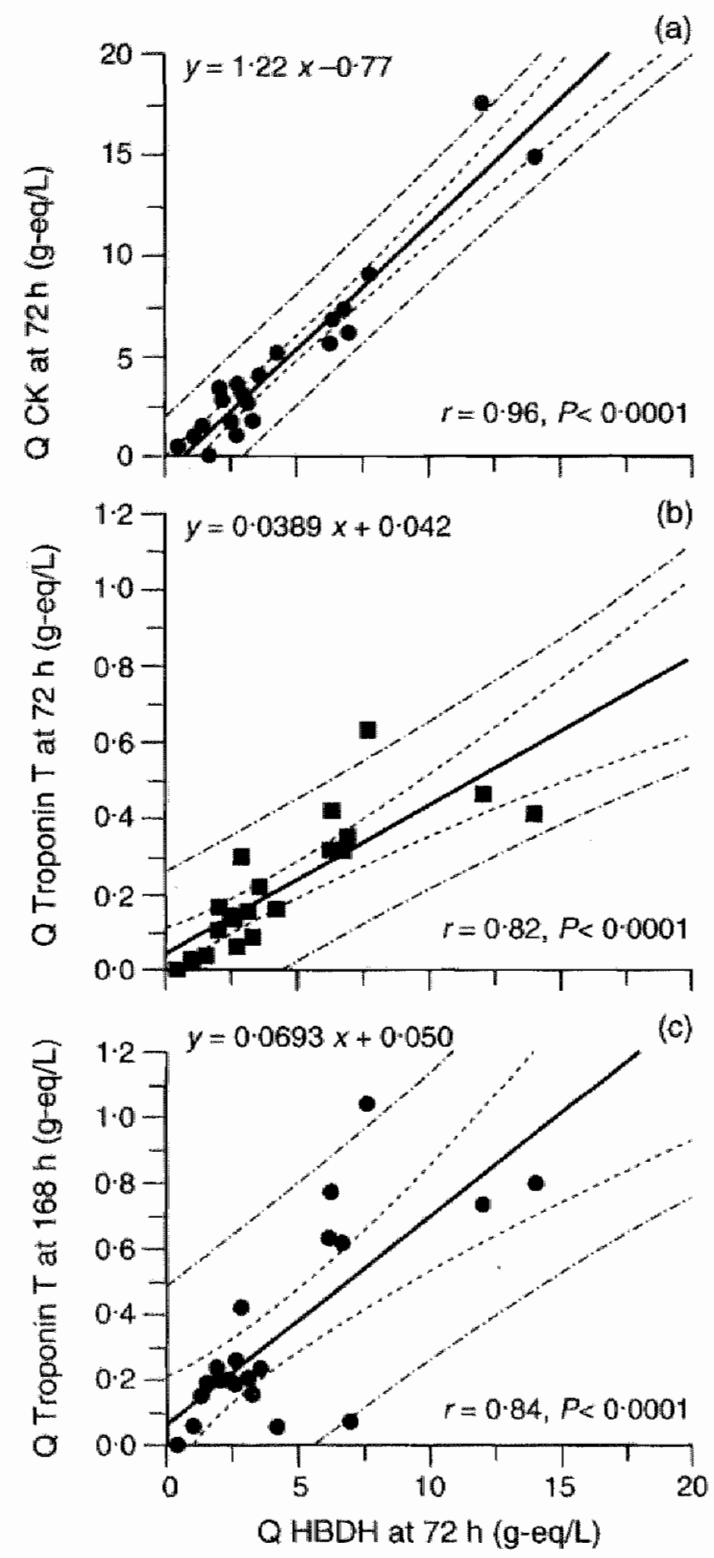

Correlation between (a) cumulative hydroxybutyrate dehydrogenase $(\mathrm{HBDH})$ and creatine kinase $(\mathrm{CK})$ and (b) HBDH and troponin T release at 72 hours and (c) at 168 hours, expressed in gram equivalents (greq) cordiac tissue and presented for 21 potients. 
Table 2

Patient data and cumulative release

\begin{tabular}{|c|c|c|c|c|c|c|c|c|c|}
\hline Patient & $\begin{array}{l}\text { Age } \\
\text { (years) }\end{array}$ & Sex & $\begin{array}{l}\text { Treatment } \\
\text { delay } \\
\text { (b) }\end{array}$ & $\begin{array}{l}\text { Q72-HBDH } \\
(\text { g-eq/L) }\end{array}$ & $\begin{array}{l}\text { Q72-Ck } \\
\text { (g-eq/L) }\end{array}$ & $\begin{array}{l}\text { Q72-LDH } \\
(\mathrm{g}-\mathrm{eq} / \mathrm{L})\end{array}$ & $\begin{array}{l}\text { Q72-TnT } \\
\text { (g-eq/L) }\end{array}$ & $\begin{array}{l}\text { Q168-Tn } \\
(\mathrm{g}-\mathrm{eq} / \mathrm{L})\end{array}$ & \\
\hline 1 & 63 & $M$ & $5 * 0$ & $2 \cdot 80$ & $3 \cdot 54$ & $3 \cdot 36$ & 0.06 & 0.19 & 648 \\
\hline 2 & 715 & $\mathbb{F}$ & $1 \cdot 1$ & $3 \cdot 37$ & 1.8 & $3 \cdot 47$ & 0.09 & $0 \cdot 15$ & $4: 5$ \\
\hline 3 & 55 & $\mathrm{~F}$ & $1 * 8$ & $1 \cdot 66$ & 0.12 & 1.08 & 0.04 & 0.05 & $3 * 0$ \\
\hline 4 & 78 & $M$ & $1 \cdot 8$ & 1.43 & 1.52 & $0 * 00$ & 0.04 & 0.07 & $4 * 9$ \\
\hline 5 & 555 & $M$ & $2 \cdot 0$ & $4 \cdot 30$ & $5 \cdot 14$ & $4 * 55$ & 0.16 & 0.23 & $5 \cdot 3$ \\
\hline 6 & 5.5 & $M$ & 1.9 & $7 \cdot 01$ & $6 \cdot 15$ & $7 * 89$ & 0.35 & 0.50 & $7 * 11$ \\
\hline 7 & 59 & $M$ & $1 \cdot 8$ & $3 \cdot 64$ & 3.99 & $3 \cdot 24$ & 0.22 & 0.35 & $9 \cdot 6$ \\
\hline 8 & 54 & $M$ & $4 \cdot 5$ & $14 \cdot 08$ & $14 \cdot 82$ & $14 * 89$ & 0.41 & 0.79 & $5 \cdot 6$ \\
\hline 9 & 68 & $\mathrm{~F}$ & $4 \cdot 0$ & $\| \cdot 08$ & $\| \cdot 02$ & 1.79 & 0.03 & 0.06 & $5 \cdot 6$ \\
\hline 10 & 5.4 & $M$ & $2 \cdot 4$ & $2 \cdot 59$ & $1 \cdot 74$ & $2 \cdot 6$ & 0.114 & 0.19 & $7 \cdot 3$ \\
\hline$\| 1$ & 55 & $M$ & $1 \cdot 8$ & 6.79 & $7 \cdot 3$ & 6.95 & 0.32 & 0.61 & $8 \cdot 9$ \\
\hline$\| 2$ & 63 & $M$ & $5 \cdot 3$ & $35 \cdot 5$ & $29 \cdot 1$ & $36 \cdot 3$ & $2 * 03$ & $3 * 56$ & $10 \cdot 2$ \\
\hline 13 & 39 & $M$ & $3 \cdot 3$ & $12 \cdot 12$ & $17 \cdot 49$ & $13 \cdot 0$ & 0.46 & 0.73 & $6 \cdot 0$ \\
\hline 14 & 62 & $F$ & 0.7 & $3 \cdot 19$ & $2 \cdot 68$ & 3.11 & 0.15 & $0 \times 20$ & $6 \cdot 2$ \\
\hline 15 & 67 & $M$ & $1 \cdot 3$ & 0.5 .1 & 0.54 & 0.4 & 0.00 & $0 \times 01$ & $2 \cdot 0$ \\
\hline 16 & 65 & $M$ & $1.8 \ldots$ & $7 \cdot 79$ & $9 \cdot 09$ & 8.63 & 0.63 & 1.013 & $13 \cdot 2$ \\
\hline 17 & 63 & $M$ & $1 \cdot 5$ & 6.3 & $5 \cdot 59$ & $5 \cdot 83$ & 0.32 & 0.62 & $9 \cdot 8$ \\
\hline 18 & 49 & $M$ & $1 \cdot 3$ & $2 \cdot 75$ & 1.07 & 2.62 & 0.13 & 0.26 & 9.4 \\
\hline 19 & 59 & $M$ & 3.0 & 6.38 & 6.85 & 6.17 & 0.42 & 0.77 & $12 \cdot 06$ \\
\hline 20 & 55 & $F$ & 1.8 & $2 \cdot 19$ & $2 \cdot 88$ & $2 \cdot 22$ & 0.16 & 0.20 & $9 \cdot 1$ \\
\hline 21 & 61 & $F$ & 0.8 & $2 \cdot 06$ & $3 \cdot 4$ & $2 \cdot 86$ & 0.10 & 0.23 & $11 \cdot 2$ \\
\hline 22 & 67 & $M$ & 1.8 & $3 \cdot 01$ & 3.09 & 2.84 & 0.30 & 0.42 & $14=0$ \\
\hline Mean & 60 & & $2 \cdot 3$ & $5 \cdot 93$ & $5 \cdot 86$ & 6.07 & 0.30 & 0.51 & \\
\hline SD & $8 \cdot 5$ & & $1 \cdot 3$ & $7 \cdot 46$ & $6 \cdot 80$ & $7 * 74$ & 0.42 & 0.75 & \\
\hline SEM & $1 * 8$ & & 0.2 & 1.59 & 1.45 & 1.65 & 0.09 & 0.16 & \\
\hline Median & 60 & & $1 \cdot 8$ & $3 \cdot 28$ & $3 \cdot 47$ & $3 \cdot 30$ & 0.16 & 0.25 & \\
\hline
\end{tabular}

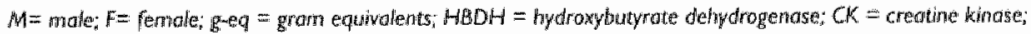

$\mathrm{EDH}=$ loctote dehydrogenase; $T$ tht $=$ Troponin $T ; S D=$ standord deviation; $S E M=$ stondard error of wien. 


\section{Tissue enzyme and troponin $\mathrm{T}$ contents}

Data on the LDH, HBDH and troponin T content in 17 myocardial autopsies are presented in Table 1 and in Fig. 2. For $\mathrm{HBDH}$ a mean tissue content of $156 \pm 25$ $\mathrm{U} / \mathrm{g}$ and for $\mathrm{LDH}$ of $385 \pm 59.4 \mathrm{U} / \mathrm{g}$ were found. For total troponin $\mathrm{T}$ a mean concentration of $234 \pm 65 \mu \mathrm{g} / \mathrm{g}$ wet weight was found.

\section{Cumulative release of enzymes into plasma}

As shown in Fig. I, CK and HBDH (or LDH) are released simultaneously and total release is completed within 72 hours. Fig. 3 also shows that the cumulatively released quantities of $\mathrm{CK}$ and $\mathrm{HBDH}$ (or $\mathrm{LDH}$ ) amount to approximately similar estimates of the extent of injury, i.e. infarct size. Mean (SEM, $n=22$ ) values for $Q$ (72) in the first 72 hours after acute myocardial infarction, were $12827 \pm 3439 \mathrm{U} / \mathrm{L}$, $925 \pm 248 \mathrm{U} / \mathrm{L}$ and $2337 \pm 635, \mathrm{U} / \mathrm{L}$ for $\mathrm{CK}, \mathrm{HBDH}$ and $\mathrm{LDH}$, respectively. When

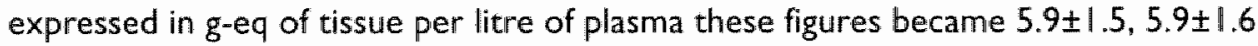
and $6.1 \pm 1.7 \mathrm{~g}$-eq/L, respectively, and these differences are obviously not statistically significantly different.

\section{Cumulative release of troponin $\mathrm{T}$ into plasma}

The mean cumulative release of troponin $T$ after 72 hours was $69.4 \pm 20.9$ $\mu \mathrm{g} / \mathrm{L}$. When expressed in $\mathrm{g}$-eq of tissue per litre plasma only $0.30 \pm 0.09 \mathrm{~g}$-eq $/ \mathrm{L}$ was released into plasma. After 168 hours the cumulative mean troponin $T$ release into plasma was $119 \pm 36.8 \mu \mathrm{g} / \mathrm{L}$ and expressed in g-eq of tissue per litre plasma a mean value of $0.51 \pm 0.16 \mathrm{~g}$-eq/L was reached. The results indicate that troponin $T$ release still continues after 168 hours (Fig. 3), while the release of CK and HBDH (or LDH) is already completed after 72 hours. After 72 hours the recovery of troponin $T$ is only $5 \%$ and after 168 hours only $8.5 \%$ of the recovery of the cytoplasmic enzymes $\mathrm{CK}$ and $\mathrm{HBDH}$ (or LDH) after 72 hours (Fig. 3).

\section{Estimation of the free troponin $\mathrm{T}$ fraction from plasma enzyme release}

In the first 24 hours mainly free cytoplasmic enzymes and proteins are released into the circulation and the biphasic plasma release of troponin $\mathrm{T}$ in Fig. I shows clearly that the release of the free cytoplasmic troponin $T$ fraction is simultaneous with the maximal CK activity. After 24 hours the cumulative CK release corresponds to the CK content of 4 grams wet weight of healthy 
myocardium. If after 24 hours the release of free cytoplasmic troponin $T$ into plasma would also correspond to the cytosolic troponin T release from $4 \mathrm{~g}$-eq myocardium, which is to be expected, the value of $40 \mu \mathrm{g} / \mathrm{L}$ for cumulative troponin $T$ release over 24 hours would imply $10 \mu$ free troponin T per gram wet weight of myocardium, that is $4.2 \%$ of total troponin $T$ content.

\section{Correlation between infarct size calculated with different markers}

Correlations between infarct size calculated from plasma curves (Table 2), using $\mathrm{HBDH}$ as a reference versus cumulative $\mathrm{CK}$ or cumulative troponin $T$ release are shown in Fig. 4. Although the mean total release of troponin $T$ after 72 hours amounts to only $0.30 \mathrm{~g}-\mathrm{eq} / \mathrm{L}$, which is only $5 \%$ of the mean total release observed for $\mathrm{HBDH}$ after 72 hours $(5.9 \mathrm{~g}$-eg/L), a highly significant correlation was observed between cumulative $\mathrm{HBDH}$ release and cumulative troponin T release after 72 hours $(r=0.82$, Fig. $4 b)$ and also with cumulative troponin T release after 168 hours $(r=0.84$, Fig. 4c). The highest correlation was observed between $Q \mathrm{HBDH}$ and $\mathrm{Q} C K$ after 72 hours ( $r=0.96$ Figure $4 a)$. One outlying patient (No. 12) with an infarct size for $C K$. $\mathrm{HBDH}$ and troponin T (at 72 hours) of, respectively, 29.1, 35.5 and $2.03 \mathrm{~g}$-eq/L is not depicted in Fig. 4 (see Table 2).

A highly significant correlation $(P<0.0001)$ was also found between cumulative $\mathrm{HBDH}$ release after 72 hours and the first $(r=0.86)$ or the second troponin $T$ peak value $(r=0.86)$. The correlation coefficient for peak $C K$ and peak $\mathrm{HBDH}$ values for these patients was even higher $(r=0.95, P<0.0001)$.

\section{Discussion}

\section{Disappearance rates from plasma cannot be used in the calculation of troponin $\mathrm{T}$ release}

When plasma protein levels have passed their maximal value and are returning to normal, there is tailing off of release of protein from the heart. Due to this continued release, the fractional rate constant $k_{d}$ for the apparent disappearence from plasma is much lower than the true clearance constant FCR. It has been shown in the dog, for instance, that the $k_{d}$ for the disappearance of CK from plasma after coronary ligation is about three times lower than FCR (17). The same is true for troponin $T$ in the present study. The calculated value of FCR $=0.1 \mathrm{I} \mathrm{h-1}$ is about three to four times higher tham the maximal disappearance rate of troponin $T$ estimated from the steepest part of the plasma curve, being about $0.03 \mathrm{~h}-1$. 


\section{Enzyme and troponin T content of cardiac tissue obtained at autopsy; effect of autolysis}

Van der Laarse (20) compared myocardial enzyme activities in cardiac biopsies with those in cardiac tissue samples obtained at autopsy and observed only a slight effect of autolysis amounting $-1 \%$ to $-6 \%$ in the first 10 hours for CK, HBDH and AST. Comparison of myocardial enzyme activities in biopsies with those obtained at autopsy, the latter being corrected for autolysis-induced inactivation, revealed significant differences for $C K$ and $A S T$, but not for $\mathrm{HBDH}$ and $L D H$ content. Van der Laarse observed an HBDH content of $123 \pm 15 \mathrm{U} / \mathrm{g}$ determined at $25^{\circ} \mathrm{C}$. Using a temperature correction factor of 1.3 (see Methods) this results in a content of $160 \pm 20 \mathrm{U} / \mathrm{g}$ wet weight, which is in accordance with the value of $156 \pm 25 \mathrm{U} / \mathrm{g}$ wet weight observed in the present study, determined at $37{ }^{\circ} \mathrm{C}$. For LDH $166 \pm 22 \mathrm{U} / \mathrm{g}$ was found by Van der Laarse (20) and using a temperature correction factor of 2.1 (see Methods), this results in an LDH content of $349 \pm 46 \mathrm{U} / \mathrm{g}$. This is slightly lower, but comparable with the $\mathrm{LDH}$ content of $385 \pm 59 \mathrm{U} / \mathrm{g}$ observed in the present study.

Very few data are available on cardiac tissue troponin $T$ content. Katus (11) determined the free troponin $T$ fraction in myocardium of three healthy donor organs and observed $24 \pm 7 \mu \mathrm{g} / \mathrm{g}$ wet weight, which represented $6 \pm 1.1 \%$ of the total troponin $T$ content, being $400 \mu \mathrm{g} / \mathrm{g}$ wet weight. We found a total troponin $T$ content of $234 \pm 65 \mu \mathrm{g} / \mathrm{g}$, and no effect of autolysis (Fig. 2). Autolysis is the destruction of tissues or organs caused by endogenous enzyme activity after death. Fig. 2 shows that there is no relation between autopsy delay (influence of autolysis) and troponin $T$ content. This might indicate that, as described for CK (20) in post-mortem cardiac samples, although the time of autopsy has no effect, a higher concentration is still found in biopsies than in material obtained at autopsy. In the present study tissue was obtained at autopsy and this might clarify the differences, although further investigation is necessary. For actomyosin preparations prepared from human myocardium, also obtained post mortem, proteolysis of troponin $T$ has been described, especially for preparations isolated from elderly subjects. However, the decrease of troponin $T$ in these preparations was not quantified (2.2). Moreover, the autopsy samples were obtained from elderly or probably cachectic subjects, and this might also cause the larger variations found for troponin $T$, although for the data presented there was no relation between patient age and troponin $T$ content. We used exactly the same procedure and the same assay conditions as described by Katus (11). Troponin $T$ was measured in all supernatants and precipitates, so recovery was complete. Further comparison of troponin $T$ content in fresh biopsies compared with autopsy material is required. The coefficient of variation of $27 \%$ for total troponin T content in Table $I$ is larger than the values found for HBDH or LDH, but comparable with those found for $\mathrm{HBDH}$ and aspartate aminotransferase in the hearts of patients who died from non-cardiac causes by Van Veen et al. (21). Differentiation of cytoplasmic from bound troponin $T$ resulted in an overestimation of the cytosolic fraction, probably caused by autolysis. Therefore we only presented the total troponin $T$ content. 


\section{Complete recovery in plasma of cytoplasmic proteins lost from the heart}

Quantitative recovery of cardiac proteins in plasma after ischaemic myocardial damage has been demonstrated in experimental studies. The total activities of CK and HBDH lost from dog heart after permanent coronary occlusion (17), equalled the total amounts of these proteins released into plasma. These results cannot be directly extrapolated to man. It was shown in the dog that protein preparations infused into infarcted myocardium reach the circulation within a few hours (23). Such a rapid washout of protein is effected by direct intravasation and flushing of the microvessels by the residual blood flow in the infarcted area. In man " conditions could be different and the washout period may be longer. However, the fact that similar estimates of infarct size are obtained for different enzymes suggest that, in man, these cytoplasmic proteins are recovered completely in plasma $(3,10)$. CK is very susceptible to inactivation but, in contrast, $\mathrm{HBDH}$ ('heat stable' $L D H$ ) is more stable. Since estimates of infarct size from $\mathrm{CK}$ and $\mathrm{HBDH}$ were simular, the effects of denaturation must be small.

\section{Quantification of cumulative troponin $\mathbf{T}$ release}

Using a total cardiac troponin T content of $234 \mu \mathrm{g} / \mathrm{g}$ (Table 1) the cumulative troponin T release after 72 hours is only $5 \%$ and after 168 hours only $8.5 \%$ of the cumulative release of cytoplasmic enzymes after 72 hours, when expressed in $\mathrm{g}$-eq of cardiac tissue (Fig. 3). Using the troponin T cardiac tissue content found by Katus of $400 \mu \mathrm{g} / \mathrm{g}(11)$, a mean cumulative release of troponin $T$ is obtained of only $0.26 \mathrm{~g}$-eq $/ \mathrm{L}$ at 72 hours, which is $4 \%$ of the cumulative enzyme release at that time. Although lower than the value obtained in the present study, this difference is insufficient to detract from the conclusion that troponin $T$ release amounts to only a small fraction $(4-5 \%)$ of total tissue content.

\section{Estimation of free cytosolic troponin $T$ release from the plasma time activity curve}

The free cytoplasmic troponin $T$ concentration extrapolated from the plasma enzyme release in the first 24 hours suggests an in wivo free cytosolic troponin $T$ fraction of $10 \mu \mathrm{g} / \mathrm{g}$ wet weight of tissue, which is $4.2 \%$ of the total troponin T content found in cardiac tissue obtained at autopsy $(234 \mu \mathrm{g} / \mathrm{g})$ and only $2.5 \%$ of the total troponin T content of $400 \mathrm{\mu g} / \mathrm{g}$ found by Katus (11) in fresh human donor hearts. 


\section{Limitations of troponin $T$ for estimation of infarct size}

Estimation of the extent of ischaemic myocardial injury from the release of cardiac enzymes into plasma has become normal clinical practice. Several clinical studies have produced convincing correlations between enzymatic and histologic estimates of infarct size (23-27). In our study the correlation between the cumulative cytoplasmic HBDH and cumulative CK release is higher $(r=0.96, n=21, P<0.0001)$ compared to the correlation between the cumulative $\mathrm{HBDH}$ and cumulative troponin $T$ release $(r=0.84, n=21, P<0.0001)$. Recently Omura (28) showed a good correlation between the late troponin $T$ peak and left ventricular ejection fraction $(r=0.68)$, injury extent score $(r=0.7 \mid)$ and severity score $(r=0.66)$. In the study a good correlation was also obtained between cumulative $\mathrm{HBDH}$ release (infarct size) and both the first troponin $T$ peak $(r=0.86, n=2 I, P<0.0001)$ and the second troponin $T$ peak $(r=0.86$, $n=21, P<0.0001$ ). These good correlations are due in part to the very frequent sampling scheme employed.

The present study shows that although cumulative troponin $T$ release is only a fraction of the cumulative enzyme release, there is a good correlation between cumulative cytoplasmic enzyme release (infarct size) and cumulative troponin $T$ release, and also between cumulative cytoplasmic enzyme release and peak troponin $T$ values. 


\section{References}

1. Anderson JL, Marshall HW, Askins JC, Lutz JR, Sorensen SG. Menlove: RL, Yanowitz FG, Hagan AD: A randomized trial of intravenous and intracoronary streptokinase in patients with acute myocardial infarction. Circulation 1984; 70:606-18.

2. The ISAM Study Group: A prospective trial on intravenous streptokinase in acute myocardial infarction. N Engl \Med 1986; 314: |465-7|

3. Simoons ML, Serruys PW, Van den Brand M, Res J. Verheugt FWA, Krauss XH, Remme WJ. Bär F, de Zwaan Ch, van der Laarse A, Vermeer F, Lubsen J: Early thrombolysis in acute myocardial infarction: Limitation of infarct size and improved survival. I Am Coll Cardiol 1986; 7: 717-28.

4. Van der Werf F. Arnold AER for the European Cooperative Study Group for recombinant tissue type plasminogen activator: Intravenous tissue plasminogen activator and size of infarct, left ventricular function and survival in acuce myocardial infarction. Br Med J 1988; 297: 1374-79.

5. The Thrombolysis Early in Acute Heart Attack Study Group: Very early thrombolytic therapy in suspected acute myacardial infarction. Am / Cardiol 1990; 65: $401-7$.

6. Karagounis L, Sorensen $S G_{n}$ Menlove RL. Moreno F. Andersen JL: Does thrombolysis in myocardial infarction (TIMII) perfusion grade 2 represent, a mostly patent artery or a mostly occluded artery? Enzymatic and electrocardiographic evidence from the TEAM-2 study. J Am Coll Cardiol 1992; 19:1-10.

7. Roberts R: Enzymatic estimation of infarct size: Thrombolysis induced its demise: Will it. now rekindle its renaissance? Circulation 1990; 81: 707-10.

8. Hermens WTh, Van der Veen FH, Willems GM, Reneman RS: Enzymatic infarct size and its significance for evaluation of thrombolytic therapy after acute myocardial infarction (Letter to the Editor). Circulation 1990; 81: 1719-20.

9. Willems GM, Visser MP, Krill MTA, Hermens WTh: Quantitative analysis of plasma enzyme levels based on simultaneous determination of different enzymes. Cardiovasc Res 1982; 16: $|20-3|$.

10. De Zwaan Ch, Willems GM, Vermeer F, Res J, Verheugt FWA, Van der Laarse A, Simoons ML, Lubsen J. Hermens. WTh: Enzyme tests in the evaluation of thrombolysis in acure myocardial infarction. Br Heart J 1988; 59: 175-83.

11. Katus HA, Remppis A, Scheffold T, Diederich KW and Kuebler W. Intracelluar compartmentation of cardiac troponim $T$ and its release kimetics in patients with reperfused and nonreperfused myocardial infarction. Am J Cardiol 1991:67:1360-7.

12. Mair J.. Artner-Dworzak E, Lechleitner P. Schmidt J. Wagner I, Dienst F and Puschendorf $B$. Cardiac troponin $T$ in diagnosis of acute myocardial infarction. Clin Chem 37:845-52, 1991.

13. Gerhardt W, Katus H, Ravkilde J. Hamm C Jorgensen P.J, Peheim E, Lungdahl Land Löfdahl P. S-troponin $T$ in suspected ischemic myocardial injury compared with mass and catalytic concentrations of s-creatine kinase isoenzyme MB. Clin Chem 1991;37:1405-11.

14. Katus HA, Remppis $A$, Looser $S$, Hallermeier $K$. Scheffold $T$ and Kübler $W$. Enzyme linked immuno assay of cardiac troponin $T$ for the detection of acute

myocardial infarction in patients. J mol Cell Cardiol 1989; 21: $1349-53$.

15. Visser MP, Krill MTA, Muijtiens AMMI, Willems GM, Hermens WTh. Distribution of enzymes in dog heart and liver. Significance for assessment of tissue damage from data on plasma enzyme activities Clin Chem 1982; 27:1845-50.

16. Visser MP, Krill MTA, Willems GM Hermens WTin: Selection af a suitable circulatory model for the plasma clearance and distribution of cardiac enzymes in the dog. Cardiovasc Res 1981; 15: 35-42. 
17. Hermens WTh, Van der Veen FH, Willems GM, Mullers-Boumans ML. Schrijvers- van Schendel A, Reneman RS: Complete recovery in plasma of enzymes lost from the heart after permanent coronary artery occlusion in the dog. Circulation 1990; 81: 649-59.

18. Van Kreel BK, Van der Veen FH, Willems GM and Hermens WTh: Circulatory models in assessment of cardiac enzyme release in dogs. Am J. Physiol. 264 (Heart Circ Physiol. 33): $4747+4754,1993$.

19. Willems GM, Visser MP, Krill MTA, Hermens WTh: Quantitative analysis of plasma enzyme levels based on simultaneous determination of different enzymes. Cardiovasc Res 1982; 16: 120-31.

20. Van der Laarse A, Dijkshoorn NJ, Hollar L, Caspers $T$. The (iso)-enzyme activities of llactate dehydrogenase, alphahydroxybutyrate dehydrogenase, creatine kinase and aspartate aminotransferase in human myocardial biopsies and autopsies. Clin Chim acta 1980; $104: 381-91$

21. Van der Veen FH, Visser R. Willems GM, Kop-Klaassen B, Hermens WTh: Myocardial enzyme depletion in infarcted human hearts: infarct size and equivalent tissue mass. Cardiovasc Res 1988; 22:611-19.

22. Yoshida K. Hanafusa T, Matoba $R$ and Wakasugi $C$ : Proteolysis of myosin and troponin $T$ in human myocardium of elderly subjects. Jpn Heart J. 1990;31:683-91.

23. Van der Veen FH. Hermens WTh, Willems GM, Schrijvers-van Schendel A, MuliersBoumans ML, Reneman RS: Time course of cellulat enzyme release in dog heart injury. Circ Res 1990;67: 1257-66.

24. Clark GL, Robison AK, Gnepp DR, Roberts R. Sobel BE: Effects of lymphatic transport of enzyme on plasma creatine kinase time-activity curves after myocardial infarction in dogs. Circ Res 1978; 43: 162-69.

25. Bleifeld W, Mathey D, Hanrath P, Buss H and Effert S: Infarct size estimated from serial creatine phosphokinase in relation to left ventricular dymamics. Circulation 1977;5:5:303-11.

26. Grande $P$, Hansen BF, Christiansen $C$, Naestoft J: Estimation of acute myocardial infarct size in men by serum CK-MB measurements. Circulation 1982;65:756-64.

27. Hackel DB, Reimer KA, Ideker RE, Mikar EM, Hartwell TD, Parker CB, Braunwald EB, Buja $M$, Gold HK et al. Comparison of enzymatic and anatomic estimates of myocardial infarct size in man. Circulation 1984:70:824-35.

28. Omura $T$, Teragaki M. Yamagishi $H$, Yanagi S, Nishikimi T, Yoshiyama M, Toda I, et al. Estimation of infarct size using serum troponin $T$ concentrations in patients with acute myocardial infarction. Jpn Circ J 1993:57:1062-70. 


\section{Chapter 3}

\section{Cumulative troponin $\mathrm{T}$ release after acute myocardial infarction. Influence of reperfusion}

Johannes A. Kragten, Wim Th. Hermens and Marja P. van Dieijen-Visser

Eur. J. Clin. Chem. Clin. Biochem. 1997; 35: 459-67 


\section{Summary}

For troponin $T$ a characteristic biphasic change in the plasma timeconcentration curve has been described, especially in patients with early reperfusion after thrombolytic therapy. As troponin $T$ is bound to myofibrillar structures, treatment strategy or treatment outcome could influence the cumulative plasma release of this protein in a different way compared to the cumulative release of free cytoplasmic cardiac enzymes.

The present study is the first study comparing the total quantity of troponin $T$ released by the heart during the first 168 hours after acute myocardial infarction, both in patients treated with thrombolytic therapy $(n=16)$ and in patients not treated with thrombolytic therapy $(n=7)$. On the basis of clinical symptoms and coronary angiogram within 24 hours, the patients treated with thrombolytic therapy were divided into two groups, reperfused $(n=9)$ and nonreperfused $(n=7)$. In the patients not treated with thrombolytic therapy absence of spontaneous early reperfusion was judged only from clinical symptoms.

Cumulative troponin $T$ release into plasma was compared to the cumulative release of the cytoplasmic cardiac enzymes creatine kinase (CK) (EC 2.7.3.2) and hydroxybutyrate dehydrogenase $(\mathrm{HBDH})(\mathrm{EC}$ I.I.I.27). Cumulative release, i.e., infarct size, was calculated using a two-compartment model for circulating proteins. Mean tissue contents, per gram wet weight, of $156 \mathrm{U} / \mathrm{g}$ for $\mathrm{HBDH}, 2163 \mathrm{U} / \mathrm{g}$ for CK and $234 \mu \mathrm{g} / \mathrm{g}$ for troponin $\mathrm{T}$ were used to express infarct size in gram-equivalents of healthy myocardium per litre plasma ( $\mathrm{g}$-eq/L).

Release rates were represented by the ratio of cumulative quantities released in 10 hours and 72 hours for $\mathrm{CK}$ and $\mathrm{HBDH}$ and in 10 hours and 168 hours for troponin $T$.

\section{Conclusions}

- Plasma time-concentration curves and release rates of troponin $T$ in patients treated with thrombolytic therapy showing reperfusion, differ significantly from those of patients not treated with thrombolytic therapy, showing no reperfusion.

- CK and HBDH release is completed within 72-100 hours in all patients, whereas troponin $T$ release still continues after 168 hours.

- Cumulative troponin T release at 168 hours is only a fraction (around $8 \%$ ) of cumulative cytoplasmic enzyme release and the percentage released is not influenced by the treatment strategy or outcome, i.e., vessel patency.

- Although troponin $T$ release is only a fraction of the cumulative enzyme release (infarct size) there is a highly significant correlation between both, independent of the treatment strategy or treatment outcome. 


\section{Introduction}

During acute myocardial infarction, failure to unblack the infarct-related vessel is associated with poor immediate outcome and longterm prognosis. It is evident: from both laboratory and clinical studies that the benefits of thrombolytic therapy are conferred by restoration of patency of the infarct-related artery (1-3). The success of reperfusion therapy is commonly assessed by the normalization of ST segment elevation in the surface electrocardiogram (ECG), the occurrence of reperfusion arrhythmias and the resolution of infarct-related chest pain (4). Predictability of reperfusion proved to be clearly insufficient in several trials using these criteria (5). To date, reliable determination of reperfusion is only possible by coronary angiography. However, acute routine angiography in all patients receiving thrombolytic therapy is impractical or unavailable in an emergency setting and may eventually cause harm to some patients. Hence, reliable methods other than angiography are needed to detect coronary reperfusion early during the hospital course. A single non-invasive marker to evaluate reperfusion would be of significant clinical benefit. The ideall application would be the use of a simple serum test as an early non-invasive method to assess successful reperfusion.

For troponin $T$ it has been suggested in several studies that the effects of reperfusion on the troponin T plasma time-concentration curves in acute myocardial infarction can be used to non-invasively assess the effectiveness of thrombolytic therapy (6-15). A characteristic biphasic change in plasma concentration has been described, especially in patients with early reperfusion after thrombolytic therapy $\{6,16,17)$. Intracellular compartmentation of troponin T, i.e., the presence of both free cytosolic and structurally bound troponin $\mathrm{T}$, seems the primary cause of this biphasic troponin $T$ release into plasma $(6,16,18)$. In fresh cardiac tissue the free cytosolic troponin $T$ fraction is about $4-6 \%$ of the total troponin $T$ content in cardiac tissue (6.19). The structurally bound troponin $T$ has to be dissociated from the contractile myofibrillar structures, before it can be released into the circulation and is therefore more slowly released into plasma compared to the free cytosolic fraction, resulting in a biphasic time-concentration curve, In the isolated perfused rat heart it was demonstrated that prolonged ischaemia induces a continuous liberation of cardiac troponin $T$, most probably from disintegrating myofibres, whereas membrane damage leads almost exclusively to leakage of a functionally unbound troponin $T$ pool. These findings may explain the biphasic serum concentration changes of cardiac troponin $T$ in patients showing reperfusion after acute myocardial infarction (18).

In a recent study, in patients treated with thrombolytic therapy, we found that the totall plasma release of troponin T after 72 hours is about $5 \%$ and after 168 hours about $8 \%$ of the total recovery of the cytoplasmic cardiac enzymes $\mathrm{CK}$ and $\mathrm{HBDH}$ after 72 hours (19). Cumulative release was expressed in g-eq of healthy heart muscle per litre plasma, i.e. infarct size $(20,21)$.

The aim of the present study is to investigate the cumulative release of troponin $T$ in different patient groups. As troponin $T$ is bound to myofibrillar 
structures, presence or absence of reperfusion within 24 hours might influence the total release of this protein in a different way compared to total plasma release of the free cytosolic cardiac markers. Therefore, the timed cumulative troponin $T$ release pattern has been compared with the cumulative release patterns of the cytoplasmic cardiac enzymes $\mathrm{CK}$ and $\mathrm{HBDH}$ in patients treated with thrombolytic therapy, both reperfused and nonreperfused and in patients not receiving thrombolytic therapy.

\section{Patients and methods}

\section{Patients}

Patients ( 12 men and II women) presented at the Department of Cardiology of the Hospital De Wever \& Gregorius in Heerlen with chest pain and ST segment elevation typical of acute myocardial infarction within 6 hours after the onset of symptoms were included in this study.

From these patients 16 ( 11 men and 5 women) were treated with thrombolytic therapy. First $160 \mathrm{mg}$ of acetylosalicylic acid (asperin) were given (unless already given by general practitioner or ambulance nurses). followed by thrombolytic therapy which consisted of 1.5 million units of streptokinase, given by infusion in $40 \mathrm{~min}$. Four hours after starting thrombolytic therapy heparin was given, 12500 units subcutaneously, every 12 hours, for 5 days.

On the basis of clinical symptoms and coronary angiography within twentyfour hours, the patients treated with thrombolytic therapy, streptokinase (S), were divided into two groups, reperfused ( $n=9$, group $\left.S^{+} R^{+}\right)$and non-reperfused $\left(n=7\right.$, group $\left.S^{+} R^{-}\right)$ patients. The third group (group S-) consisted of seven patients ( 6 women and I man) not treated with thrombolytic therapy. In this group no coronary angiography was performed and the absence of reperfusion was judged from clinical symptoms only.

All patients included in the study had given informed consent. Excluded were patients with increased risk of bleeding, prewious coronary bypass surgery or $\mathrm{Q}$-wave infarction in the same location, severe hepatic or renal disease, or inability to give informed consent.

Venous blood samples of $10 \mathrm{ml}$ were obtained just before starting thrombolytic therapy and $1,2,3,4,5,6,8,10,14,18,22,28,34,46,58,70,82,94$, $118,142,166$ hours later. Exact sampling times were recorded and expressed as time after the onset of symptoms. Most samples were taken from indwelling catheters and care was taken to prevent haemolysis. Contamination with infused solutions was prevented by using a second catheter for infusion purposes. Blood was collected in pre-distributed and labeled tubes, containing dry heparin to prevent clotting and was taken to the laboratory immediarely. Plasma samples, obtained after routine centrifugation, were stored at $-70^{\circ} \mathrm{C}$ until analysis. All procedures followed were approved by the Medical Ethical Committee of the Hospital. Patient data for the three groups are presented in Table 1 . 


\section{Table I}

\section{Patient data}

\begin{tabular}{|c|c|c|c|c|c|c|}
\hline Patient group & $\begin{array}{l}S^{+} \mathbb{R}^{*} \\
(n=9) \\
\text { mean } \pm S D\end{array}$ & $\begin{array}{l}\mathbf{S}+\mathbf{R} \\
(n=7) \\
\text { meantSD }\end{array}$ & $\begin{array}{l}S \\
(n=7) \\
\text { meantSD }\end{array}$ & $\begin{array}{l}S^{+} \mathrm{F}^{*} \\
\text { vs S- }\end{array}$ & $\begin{array}{l}\mathbf{S}+\mathbf{R} \\
\text { vis } \mathbf{S}\end{array}$ & $\begin{array}{l}S^{*}+\mathbf{R}^{*} \\
\text { vs } \mathbf{S}^{+} \mathbf{R}^{+}\end{array}$ \\
\hline Treatment delay [h] & $2.23 \pm 1.32$ & $2.28 \pm 1.41$ & $2.2 \| \pm 1.09$ & ns & ns & ns \\
\hline Age $[$ years $]$ & $61.4 \pm 11.3$ & $58.1 \pm 6.7$ & $72.7 \pm 8.6$ & ns & 0.015 & ins. \\
\hline Time peak CK [h] & $\| 2.0 \pm 3.4$ & $15.3 \pm 5.9$ & $19.7 \pm 6.5$ & 0.019 & ns & ns. \\
\hline Time peak $\mathrm{HBDH}[\mathrm{h}]$ & $21.3 \pm 6.02$ & $2.3 \pm 5.5$ & $44.3 \pm 23.5$ & 0.014 & 0.022 & nisi \\
\hline Time peak troponin $T[\mathrm{~h}]$ & $12.9 \pm 3.82$ & $0.0 \pm 8.62$ & $4.0 \pm 10.1$ & 0.020 & ns & 0.05 \\
\hline troponin $T$ at $16 \mathrm{~h} /$ troponin $T$ at $36 \mathrm{~h}$ & $2.04 \pm 0.85$ & $2.02 \pm 0.91$ & $0.94 \pm 0.65$ & 0.016 & ns & ns \\
\hline Q HBDH $(72)[\mathrm{g}-\mathrm{eq} / \mathrm{l}]$ & $5.23 \pm 2.89$ & $5.28 \pm 4.67$ & $6.44 \pm 4.97$ & ns & $\mathrm{ns}$ & ns \\
\hline$Q \subset K(72)[g-e q /]$ & $5.32 \pm 4.90$ & $5.49 \pm 5.02$ & $6.52 \pm 6.50$ & $\mathrm{~ms}$ & ns & ns \\
\hline Q troponin $T(72)[\mathrm{g}-\mathrm{eq} /]$ & $0.21 \pm 0.16$ & $0.26 \pm 0.21$ & $0.22 \pm 0.16$ & ns & ins & ns \\
\hline Q troponin $T(168)[\mathrm{g}-\mathrm{eq} / \mathrm{l}]$ & $0.36 \pm 0.27$ & $0.44 \pm 0.36$ & $0.50 \pm 0.38$ & ns & ns & mas \\
\hline Q troponin T (168)/Q HBDH (72) $\times 100[\%]$ & $6.6 \pm 3.3$ & $8.7 \pm 2.9$ & $8.6 \pm 2.4$ & ns. & ns & ns \\
\hline$Q$ troponin T (168)/ Q HBDH $(168) \times 100[\%]$ & $6.1 \pm 2.9$ & $8.3 \pm 3.0$ & $7.8 \pm 2.4$ & ns: & ns & ns \\
\hline $\mathrm{QHBDH}(24) / \mathrm{QHBDH}(72) \times 100[\%]$ & $66.7 \pm 16.9$ & $72.7 \pm 15.7$ & $55.7 \pm 21.2$ & ns & ms & ns \\
\hline $\mathrm{QHBDH}(10) / \mathrm{Q} \mathrm{HBDH}(72) \times 100[\%]$ & $35.7 \pm 116.8$ & $34.5 \pm 20.4$ & $13.2 \pm 12.3$ & 0.018 & ans & ns \\
\hline$Q C K(\| 0) / Q C K(72) \times 100[\%]$ & $30.4 \pm 14.3$ & $28.5 \pm 16.1$ & $19.7 \pm 32$ & 0.052 & $\mathrm{~ns}$ & $\mathrm{~ns}$ \\
\hline$Q$ troponin T (10)/Q troponin T (168) $\times 100[\%]$ & $22.2 \pm 18.5$ & $12.7 \pm 10.7$ & $5.4 \pm 6.10 .0$ & 0.008 & ns & ns \\
\hline$Q$ troponin $T(5) / Q$ troponin $T(168) \times 100[\%]$ & $14.9 \pm 25.9$ & $3.0 \pm 3.23$ & $.2 \pm 5.6$ & ns & ns & ns \\
\hline
\end{tabular}

\footnotetext{
$S+R^{+} \quad=$ streptokinose trectment, reperfusion

$S^{*} R-\quad=$ streptokinose treatment, no reperfusion

S- $\quad=$ no streptokinase treatment

$C K=$ creatine kinose

$\mathrm{HBDH}=a$-thydroxybutyrate delaydrogenose
} 


\section{Enzyme and troponin T assays}

\section{Creatine kinase and hydroxybutyrate dehydrogenase}

Enzymatic activities of $\mathrm{CK}$ and $\mathrm{HBDH}$ were measured spectrophotometrically at $37{ }^{\circ} \mathrm{C}$ using a centrifugal analyser (Cobas Bio System, Hoffmann La Roche, Basel, Switzerland). Commercially available test kits were used for CK-N-acetylcysteine (International Federation of Clinical Chemistry (IFCC) recommendation, Unimate 3 Roche, art no 0736473 ) and HBDH (Deutsche Gesellschaft für Klinische Chemie (DGKC) recommendation, optimized test from Boehringer, art no. 1442 589). The $H B D H$ test is based on preferential catalytic activity of the myocardial isoforms $L D H_{1}$ and $\mathrm{LDH}_{2}$ of lactate dehydrogenase in the conversion of $\alpha$-ketobutyrate. Activities were expressed in micromoles of substrate converted per minute $(U)$, either per litre of plasma $(U / L)$ or per gram wet weight of tissue $(U / g)$.

\section{Troponin T}

Troponin $T$ was measured using the troponin $T$ immunoassay from Boehringer Mannheim (22). The assay was carried out in coated tubes, using the Boehringer Mannheim ES22 photometer.

\section{Cumulative release of enzymes and troponin $\mathrm{T}$ into plasma}

$Q(t)$, the cumulative release of enzyme activity and troponin $T$ concentration per litre of plasma from the onset of acute myocardial infarction $(t=0)$ up to time $t$, was calculated with the following expression for a two-compartment model for circulating proteins:

$$
Q(t)=C(t)+T E R \int_{0}^{t} \exp \{-\operatorname{ERR}(t-\tau)\} C(\tau) d \tau+F C R \int_{0} t C(\tau) d \tau
$$

The three terms are the enzyme activity in plasma, the extravasated activity and the activity eliminated from plasma, all three expressed per litre of plasma. The parameters TER, ERR and FCR represent the fractional rate constants for transcapillary escape, extravascular return and fractional catabolism, respectively. This two-compartment model has been validated in the dog $(21,23,24)$ and parameter values estimated in man are (20):

$$
F_{\mathrm{HBDH}}=0.015 \mathrm{~h}^{-1}, \mathrm{FCR}_{\mathrm{CK}}=0.20 \mathrm{~h}^{-1}, \mathrm{TER}=0.014 \mathrm{~h}^{-1} \text { and } \mathrm{ERR}=0.018 \mathrm{~h}^{-1} \text {. }
$$


For troponin $T$, a value of $F C R=0.11 \pm 0.05 \mathrm{~h}^{-1}($ mean $\pm S D)$ was obtained from a fitting procedure on troponin $\mathrm{T}$ and $\mathrm{HBDH}$ plasma curves, as described by Willems et al. $(19,20)$. The procedure is based on simultaneous release of the two proteins from the same (cytoplasmic) compartment, that is, the released troponin $T$ should be the free cytosolic fraction. Therefore fitting was limited to the first 24 hours after first symptoms and it was verified that fitting over 18 or 30 hours gave similar results, which indicates that the rellease of fibrillar troponin $T$ remains negligible during this period. The mean obtained value of $F C R_{\text {troponin } T}=0.11 \mathrm{~h}^{-1}$ was used in the calculations (19).

The calculations are not influenced by the plasma release rates. Knowledge of the clearance and extravasation rates of proteins once entered into the circulation are sufficient for calculation of the cumulative release into the plasma compartment (25). The two pools used in the two-compartment model are the intra- and excravascular pool and not the free and bound proteins. So with the twocompartment model for circulating proteins, the amount of protein entering the circulation can be calculated. The model has been extensively verified both in animal and in experimental studies $(20,24-27)$.

Plasma enzyme activities measured at time $t, C(t)$, were corrected by subtraction of the normal steady-state activities $C_{s}$. If the first plasma sample was obtained within 4 hours after the onset of symptoms, the corresponding enzyme activities were used for $\mathrm{C}_{\mathrm{s}}$. In the remaining cases, fixed mean values of $100 \mathrm{U} / \mathrm{L}, 1 / 2$ $\mathrm{U} / \mathrm{L}$ and $0 \mu \mathrm{g} / \mathrm{L}$ were used for $\mathrm{CK}, \mathrm{HBDH}$ and troponin $\mathrm{T}$, respectively.

\section{Infarct size in g-eq of tissue per litre of plasma}

In order to express myocardial injury in g-eq of healthy myocardium per litre of plasma, the cumulative release of enzyme per litre of plasma was divided by the respective enzyme content per gram wet weight of cardiac tissue. For CK $2 \| 63 \mathrm{U} / \mathrm{g}$ wet weight, for HBDH $156 \mathrm{U} / \mathrm{g}$ and for troponin $\mathrm{T} 234 \mu \mathrm{g} / \mathrm{g}$ was used (19.28).

\section{Statistical analysis}

The release curves of proteins into plasma are presented as means with standard error of the mean (SEM). Pearsons correlation coefficient was calculated to show relations between cumulative enzyme and troponin $T$ release. The Mann Whitney $U$-test was used for non-parametric comparison of data of two independent groups. The level of significance was set at $p<0.05$. 


\section{Figure Ia-c}
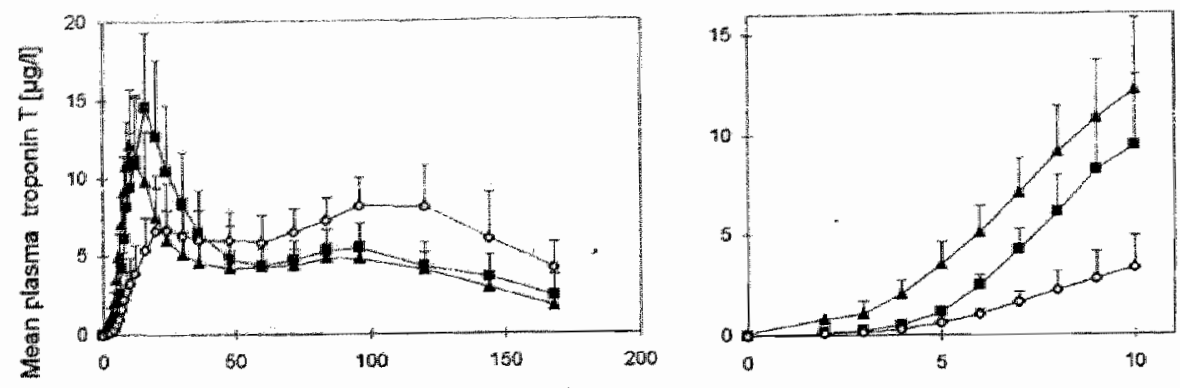

过
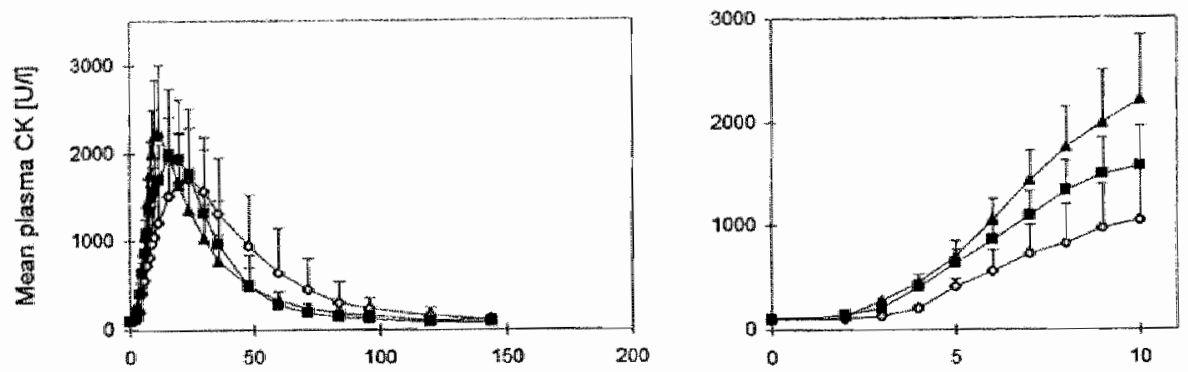

b
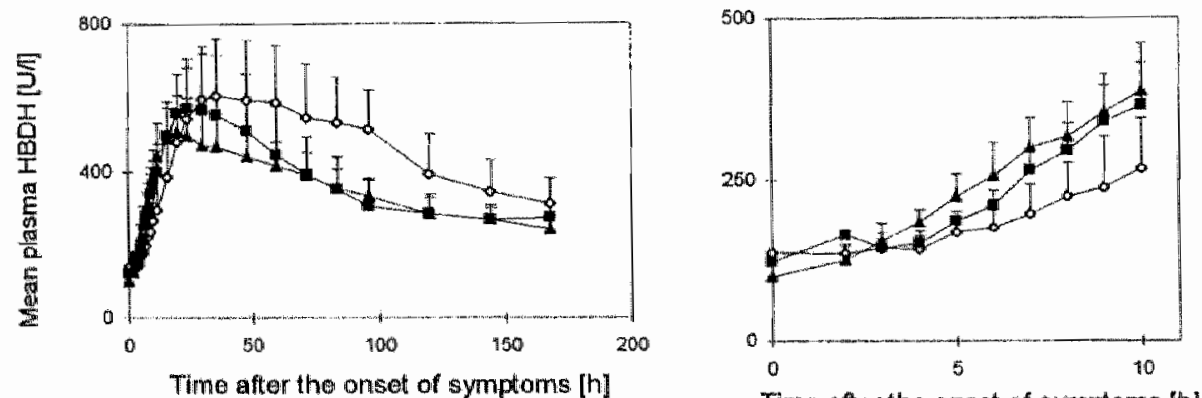

Time after the onset of symptoms [h]

Mean plasma comcentrotions of tropanin $T \times 100 \mathrm{inm}$ microgram per litre (a) and of $C K(b)$ and HBDH $(\mathrm{C})$ expressed in Uh, in potients treated with thrombolytic therapy, with reperfusion $\left(4, S^{*} R^{*}, n=9\right)$ or without reperfusion $\left(\mathbf{C}, S^{*}, n=7\right)$ and in patients not treated with thrombolytic therapy and showing no reperfision $(0,5, n=7)$.

Upper standard error of mean (SEM) is indicated. 


\section{Figure 2a-c}
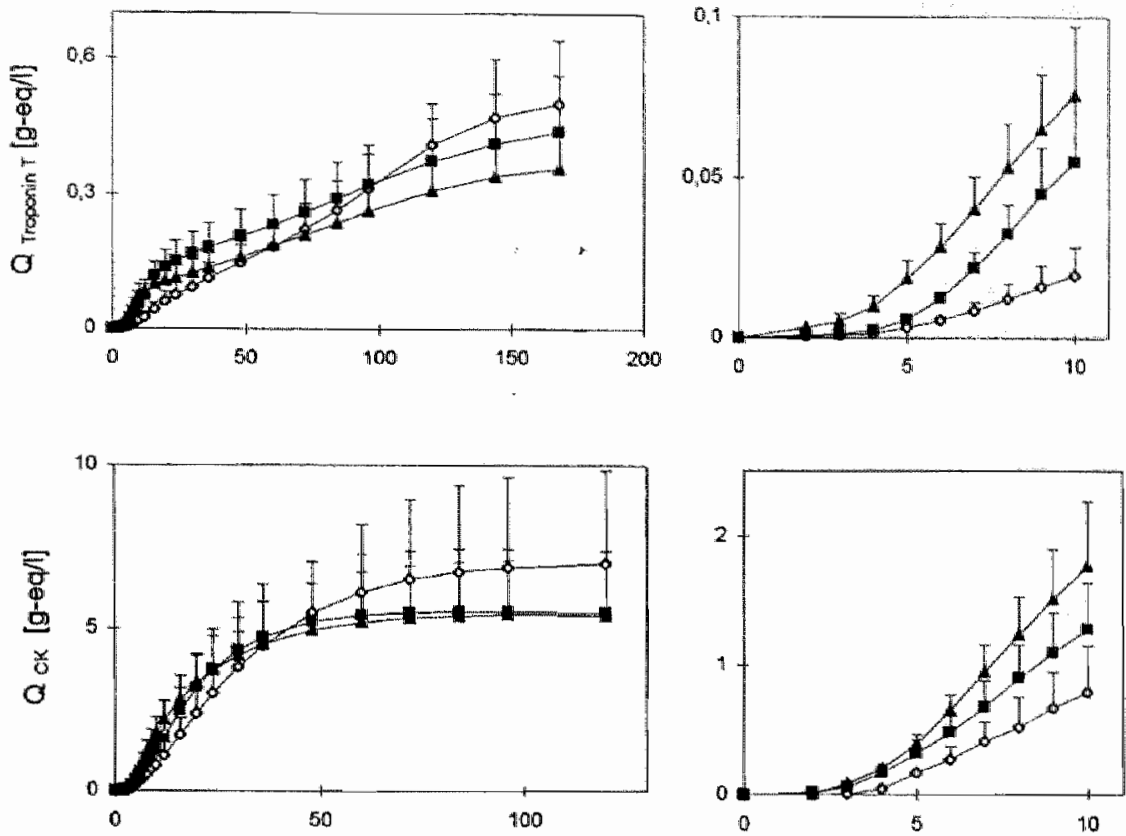

b
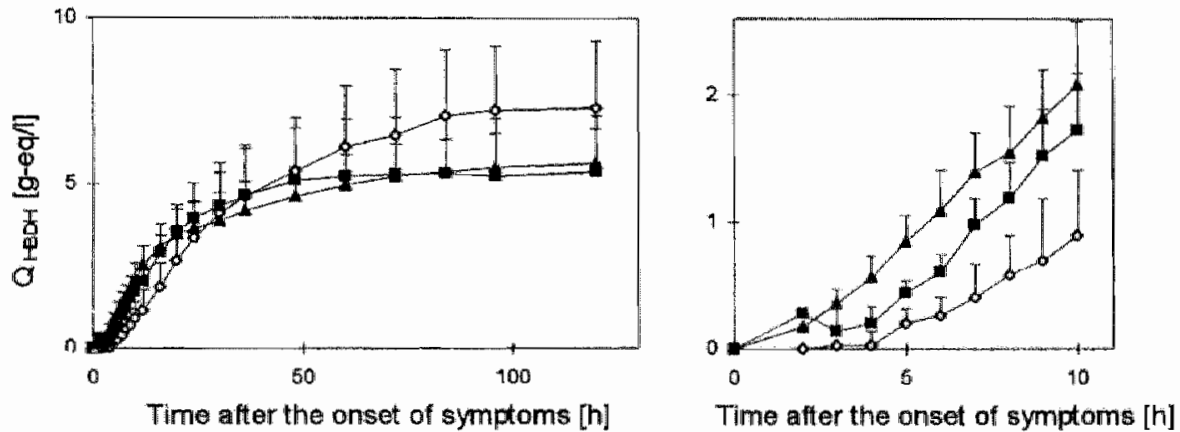

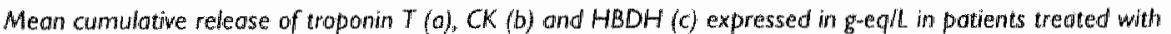
thrombalytic therapy, with reperfusion $\left(\Delta, S^{*} R^{*}, n=9\right)$ or without reperfusion $\left(a, S^{*} R_{n}, n=7\right)$ and in potients not treoted with thrombolytic therapy $(0,5, n=7)$

Upper standord error of the mean (SEM) is indicoted. 


\section{Figure 3a-c}

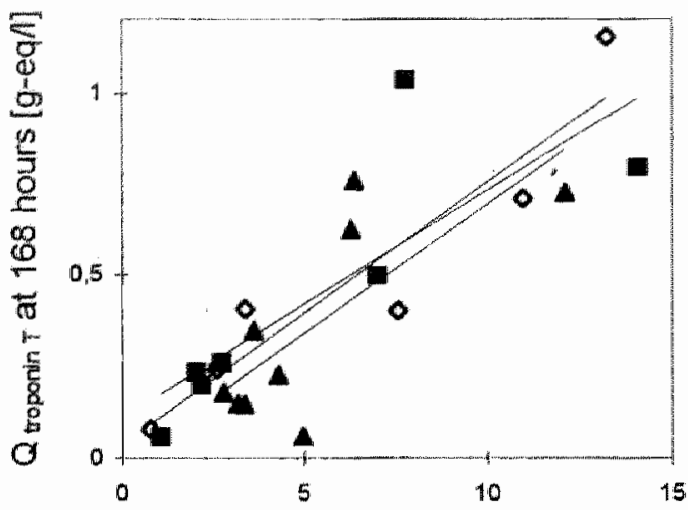

a

$$
\begin{aligned}
& \text { Regrassion lines: } \\
& \text { Fing. } 3 \mathrm{at} \\
& \Delta_{r}=0.92 ; y=0.071 \times 0.013 \\
& a_{i}=0.95 ; y=0.063 x+0.109 \\
& 0 r=0.96 y=0.072 x+0.036
\end{aligned}
$$

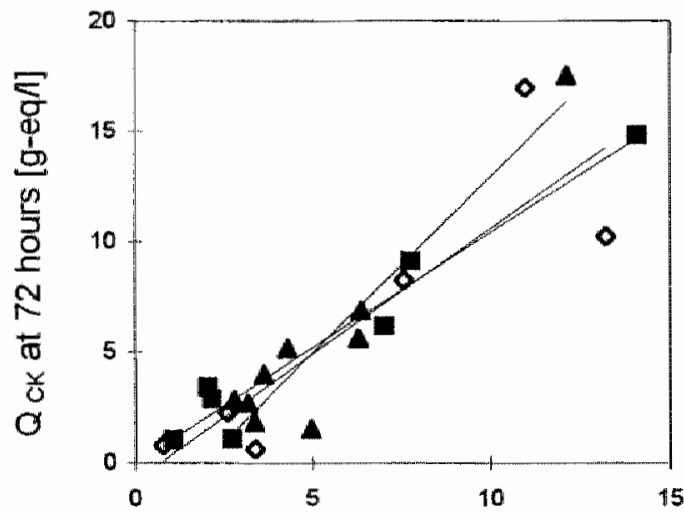

fig. $30:$
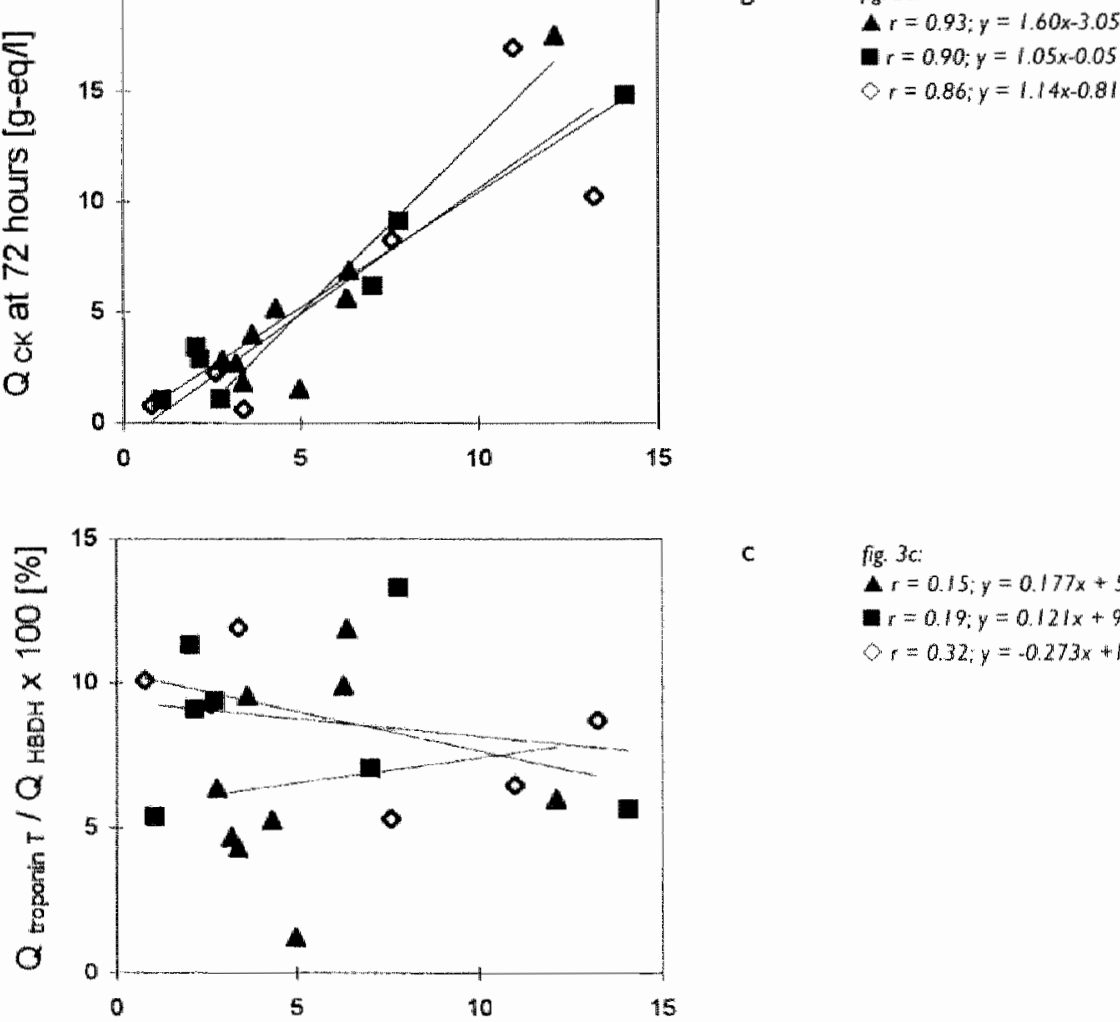

c

fig. $3 x:$

$$
\begin{aligned}
& \Delta r=0.15 ; y=0.177 x+5.6 \\
& \mathbf{v}=0.19 ; y=0.121 x+9.4 \\
& r=0.32 ; y=0.273 x+10.4
\end{aligned}
$$

Correfotion between cumulative $\mathrm{HBCH}$ release ot 72 hours and cumulative troponin $T$ release at 168 hours (a) and Between $H B D H$ and cumblative CK release at 72 hours (b). expressed in g-eg cardioc tissue per litre plasma in patients treated with thrombolytic therapy, with reperfusian $\left(\boldsymbol{\Lambda}, S^{+} R^{+}, n=9\right)$ or without reperfusion $\left(\boldsymbol{D}, S^{*} R, n=7\right)$ and in patients not treoted with thrombolytic theropy shawing no reperfusion $(05, n=7)$. Fig. $3 c$ presents the relation

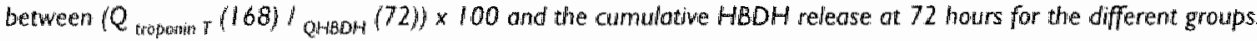




\section{Results}

\section{Mean plasma concentration after acute myocardial infarction}

Mean plasma troponin T concentrations and $\mathrm{CK}$ and $\mathrm{HBDH}$ activities as a function of time after the onset of symptoms in the three patient groups are shown respectively in the Figures la, b, c. At the right side of each figure an enlargement of the plasma release curves during the first 10 hours is given. Differences in time from onset of symptoms to peak are most significant between patients treated with thrombolytic therapy without reperfusion (group $S^{+} R-$ ) compared to patients not treated with thrombolytic therapy, showing no reperfusion (S)), see Table I.

The biphasic troponin $T$ curve clearly indicates a second source of release, starting about 40 hours after the onset of symptoms. The biphasic troponin $T$ release is more clear in patients treated with thrombolytic therapy compared to patients not treated with thrombolytic therapy. In patients not treated with thrombolytic therapy, showing no reperfusion, delayed time to peak values were found for all cardiac markers studied and for troponin $T$ the ratio of plasma troponin $T$ at $16 \mathrm{~h}$ to $36 \mathrm{~h}$ was significantly lower in the nontreated nonreperfused patients (Table I).

\section{Cumulative release of enzymes into plasma}

For troponin $\mathrm{T}, \mathrm{CK}$ and $\mathrm{HBDH}$ the time versus cumulative release, expressed in gram-equivalents of tissue per litre of plasma, is shown respectively in the Figures $2 \mathrm{a}, \mathrm{b}$ and $\mathrm{c}$. At the right side of each figure an enlargement of the cumulative release during the first 10 hours is given. Figure 2 and Table 1 show that the cumulatively released quantities of $\mathrm{CK}$ and $\mathrm{HBDH}$ amount to approximately similar estimates of the extent of injury, i.e., infarct size after 72 to 100 hours. Cumulative troponin T release is still continuing after 168 hours and is only a fraction of cumulative enzyme release.

\section{Cumulative release of troponin $\mathrm{T}$ into plasma}

After 168 hours the mean troponin T release, expressed as a percentage of the cumulative enzyme release, is comparable between the groups and is only 6.6 to $8.7 \%$ of the cumulative enzyme release after 72 hours (Table 1). Figure 2a shows that troponin T release still continues after 168 hours, whereas the release of CK and $\mathrm{HBDH}$ is already completed after $72-100$ hours. 


\section{Correlation between infarct size calculated with different cardiac markers}

Figure 3 shows that although the mean total release of troponin $T$ after 72 hours is only a fraction of the mean total release observed for HBDH after 72 hours, a highly significant correlation is observed between cumulative $\mathrm{HBDH}$ release and cumulative troponin $T$ after 168 hours for all three groups. Slope and intercept of the regression lines are comparable, indicating that the total cumulative release of troponin $T$ is not influenced by treatment strategy or outcome.

Figure 3 shows that the percentage troponin $T$ released is not influenced by infarct size.

\section{Discussion}

\section{Patient groups}

Since the introduction of thrombolysis this therapy has proven to be very effective in patients suffering from acute myocardial infarction. For that reason every patient with signs of acute myocardial infarction will be stratified for thrombolysis, unless there is a significant contra-indication. Mostly these contra indications are: time passed since the onset of symptoms (i.e. $>6-9$ hours), a history of recent cerebrovascular accident or a history of gastro-intestinal bleeding or ulcer. It goes without saying that these factors influence the composition of the two different groups, so that it is very difficult to include a group of patients receiving no thrombolytic therapy, that matches the other group. In the present study treatment delay was comparable between the groups.

As we primarily investigated differences in cumulative release between the groups, clinical symptoms and coronary angiography within 24 hours were sufficient to determine vessel patency. Patients with completely different vessel patency were present and therefore a possible influence of vessel patency on the cumulative release of troponin $T$ could be investigated bij comparing cumulative enzyme and cumulative troponin $T$ release; especially since it is known that cumulative enzyme release, i.e. enzymatic infarct size, is not influenced by vessel patency (29). Van der Laarse showed that the relation between enzymatic infarct size assessed from cumulative $\mathrm{HBDH}$ release and left ventricular performance was not influenced by the presence or absence of reperfusion (29). Of course in studies on early prediction of vessel patency, 90 minutes angiography should be preferred to judge the presence or absence of early reperfusion. 


\section{Troponin $\mathbf{T}$ and prediction of reperfusion}

Clinicall assessment of reperfusion following thrombolytic therapy is an important feature for a clinician. As a gold standard coronary angiography "performed ninety minutes after start of thrombolytic therapy offers a clear view of the status of the infarct-related vessel, but is expensive, and may cause harm to the patient (5). Clinical assessment of reperfusion on ECG-changes and ventricular arrhythmias alone, however is related with a lower prognostic value, so the use of acute biochemical markers is essential and has been the subject of many investigations (7.26). Troponin $T$ has also been suggested as a biochemical marker of reperfusion $(6,8,12,14)$. Katus et al. first showed the characteristic biphasic plasma time-concentration curve for troponin $T$ and indicated that all patients with reperfusion $<5.5$ hours after the onset of acute myocardial infarction had a ratio of peak troponin $T$ on day 1 , to day 4 of $>1.0$. The ratio was $<1.0$ in nonreperfused patients and in those with reperfusion after 5.5 hours (6).

Burlina et al. found $94 \%$ efficiency using the ratio of serum troponin $\mathrm{T}$ at $16 \mathrm{~h}$ to serum troponin $\mathrm{T}$ at $32 \mathrm{~h}$ after onset of chest pain. However, in this study most of the nonreperfused patients were not treated with thrombolytic therapy and reperfusion was detected from clinical symptoms and was confirmed angiographically only in some cases (31).

Rempis et al. demonstrated that the probability of reperfusion was $>95 \%$ when the ratio of troponin T concentration at 14 hours over 38 hours exceeded 1.09. They showed a much better discriminating value of this ratio in patients with reperfusion occurring within 4 hours after start of treatment (112). We could confirm their results in nonreperfused nontreated patients compared to reperfused treated patients. In patients treated with thrombolytic therapy, assessment of reperfusion from the troponin $T(16 / 36)$ ratio was not possible. This might be caused by the fact that we determined vessel patency within 24 hours and not within 90 minutes. So, in our patients reperfusion did not necessarily occur within 4 hours after start of treatment. This does not interfere with our goal to compare the total amount of troponin T released in the different patient groups.

For reliable prediction of thrombolysis from initial slopes of cardiac markers samples should be taken every 15 minutes after start of treatment to estimate the initial slope $(8,10,14)$. Using early initial slopes of serum markers to predict reperfusion Zabel et al. found the best discriminating results using myoglobin. Compared to troponin $\mathrm{T}$ or $\mathrm{CK}-\mathrm{MB}_{\text {mass }}$ initial slopes, myoglobin showed earlier rise, yielding a better negative predictive value and a higher area under the ROC curve for noninwasive prediction of coronary artery patency after thrombolytic therapy (B) Abe et al. found a comparable accuracy of $92 \%$ to predict reperfusion from initial slope measurements for $C K-M B_{\text {mass }}$ and troponin T. Initial slopes were obtained from 15 minute samples during the first 90 minutes (10). Laperche et al. showed that relliable early noninvasive diagnosis of patency after thrombolysis from plasma myoglobin or 
troponin $T$ is only possible in patients treated $>3$ hours after onset of symptoms by use of criteria derived from the relative increase over 90 minutes (14).

The aim of the present study was not to predict reperfusion from plasma time activity ar concentration curves, but to investigate the cumulative release of troponin $T$, as a percentage of cumulative cytosolic enzyme release in different patient groups. As troponin $T$ is bound to myofibrillar structures, presence or absence of reperfusion might influence the cumulative release of this protein in a different way compared to the free cytosolic enzymes: especially because it is known that cumulative enzyme release i.e. enzymatic infarct size is not influenced by vessel patency (29). Van der Laorse et al. showed that the relation between enzymatic infarct size assessed from cumulative $\mathrm{HBDH}$ release and left ventricular performance was not influenced by the presence or absence of reperfusion (29). As we studied cumulative release, plasma time-concentration curves and cumulative release patterns were indicated and calculated from the onset of symptoms and not from the onset of treatment. The latter is only to be preferred in studies on prediction of reperfusion from initial slopes.

Only few studies are available on the influence of reperfusion or treatment of thrombolytic therapy on cumulative enzyme release i.e. infarct size or release rate. In a large scale study Van der Loarse et al. found that thrombolysis in the early phase of acute myocardial infarction limits infarct size and that intracoronary streptokinase treatment itself positively influences the enzyme release rate from the infarcted myocardium, independent of treatment outcome determined angiographically (29). In the present study a comparable trend is shown although not significant. A larger study is necessary to confirm these findings.

\section{Recovery of the different markers}

Quantitative recovery of cytosolic cardiac proteins into plasma after ischaemic myocardial damage has been demonstrated in experimental studies. The total activities of free cytosolic $\mathrm{CK}$ and $\mathrm{HBDH}$ lost from dog heart after permanent coronary occlusion (21), equaled the total release of these proteins into plasma. These results cannot be directly extrapolated to man. It was shown in the dog that protein preparations infused into the infarcted myocardium reach the circulation within a few hours (27). Such a rapid washout of protein is effected by direct extravasation and flushing of the micro-vessels by the residual blood flow in the infarcted area. In man, conditions could be different and the washout period may be longer. However, the fact that similar estimates of infarct size are obtained for enzymes indicates that, also in man, these cytoplasmic proteins are recovered completely in plasma within 72-100 hours after the onset of symptoms (32.33).

In a recent study we found that in patients receiving thrombolytic therapy, cumulative troponin $T$ release is only a fraction of cumulative cytoplasmic CK or $\mathrm{HBDH}$ release (19). Using a total cardiac troponin T content of $234 \mu \mathrm{g} / \mathrm{g}$ wet weight the mean cumulative troponin T release after 168 hours is about $8 \%$ of the cumulative 
release of cytoplasmic enzymes after 72 hours, when expressed in g-eq normal cardiac tissue. So, for proteins bound to myofibrillar structures there is no rapid washout, and only the free circulating troponin $T$ and the troponin $T$ released from the myofibrils after ischaemia reaches the circulation. This is only a small fraction of the total amount of troponin T present in cardiac tissue (19). From the present study it became clear that cumulative troponin $T$ release is independent of treatment strategy or outcome. Figure $3 a$ shows that the correlation and slope of cumulative $\mathrm{HBDH}$ versus troponin T release is not influenced by treatment strategy or outcome. Moreover, the percentage of troponin $T$ released is not influenced by infanct size (Fig. 3c).

\section{Troponin $\mathrm{T}$ for estimation of infarct size}

Estimation of the extent of ischaemic myocardial injury from the release of cytoplasmic cardiac enzymes into plasma has become normal clinical practice and has been applied succesfully in the evaluation of the effect of thrombolytic therapy after acute myocardial infarction (32.34.35). Several clinical studies have produced convincing correlations between enzymatic and histologic estimates of infarct size or between enzymatic infarct size and infarct size estimated from photon-emission computed tomography (40) or radionuclide estimates of myocardial infarct size (26,27.36-39).

We showed that, although cumulative troponin $T$ release is only a fraction of the cumulative enzyme release, there is a good correlation between cumulative cytoplasmic enzyme release (infarct size) and cumulative troponin $\mathrm{T}$ release, independent of treatment strategy or treatment outcome and vessel patency (Fig. 3a-b). 


\section{Conclusions}

- $\mathrm{CK}$ and HBDH release was completed within 72-100 hours in all patients, whereas troponin $T$ release was still continuing after 168 hours.

- There was a significant difference in time to peak value for cardiac enzymes and troponin $T$ in patients treated with thrombolytic therapy, showing reperfusion compared to those not treated with thrombolytic therapy showing no reperfusion.

- Although plasma time concentration curves of troponin $T$ in patients treated with trombolytic therapy showing reperfusion, differed significantly from data of patients not treated with thrombolytic therapy and showing no reperfusion, after 168 hours the cumulative troponin $T$ release was only $6-8 \%$ of the cardiac enzyme release for all patients and is therefore not influenced by the treatment strategy.

- Although cumulative troponin $T$ release is only a fraction of the cumulative enzyme release, there is a good correlation between cumulative cytoplasmic enzyme release (infarct size) and cumulative troponin $T$ release, independent of treatment strategy or treatment outcome and vessel patency.

- The rate of enzyme and troponin $T$ release in patients treated with streptokinase seems higher than the release rate in patients not treated with streptokinase and without spontaneous reperfusion. This could mean a direct effect of the thrombolytic agent on the release rate of troponin $T$. A more extensive study is neccessary to confirm this finding. 


\section{References}

1. Kennedy JW, Ritchie JL, Davis KB, Stadius ML, Maynard C. Fritz JK. The Western Washington randomized trial of intracoronary streptokinase in acute myocardial infarction. New Engl」 Med 1985; 312: 1073-8.

2. GISSI-I. (Gruppo Italiano per lo studio della streptochinasi nellinfarto miocardico) Effectiveness of intravenous thrombolytic treatment in acute myocardial infarction. Lancet 1986; i: 349-60.

3. Tiefenbrunn AJ, Sobel BE. Thrombolysis and myocardial infarction. Fibrinolysis $199 \| ; 5: 1=15$.

4. Kircher B], Topol BJ, O'Neill WWW, Pitt B. Prediction of infarct coronary artery recanalization after intravenous thrombolytic therapy. Am J Coll Cardiol 1987; 59:513-5.

5. Califf RM, O'Neill W, Stack RS, Aronson L, Mark DB, Mantell S, et al. Failure of simple clinical measurements to predict perfusion status after intravenous thrombolysis. Ann Intern Med 1988; 108: 658-62.

6. Katus HA, Remppis $A$, Scheffold $T$, Diederich KW, Kuebler WN. Intracellular compartmentation of cardiac troponin $T$ and its release kinetics in patients with reperfused and nonreperfused myocardial infarction. Am $\|$ Cardial $\| 991 ; 67:$ 1360-7.

7. Apple FS. Acute myocardial infarction and coronary reperfusion. Serum cardiac markers for the 1990s. Review. A J C P 1992; 97; 217-26.

8. Zabel M, Hohnloser SH, Koster W, Prinz M, Kasper $W_{x}$ Just $H$. Analysis of creatine kinase, CK-MB, myoglobin, and troponin $T$ time-activity curves for early assessment of coronary artery reperfusion after intravenous thrombolysis. Cinculation 1993; 87: 1542-50.

9. Mair J, Puschendorf B, Michel G. Clinical significance of cardiac contractile proteins for the diagnosis of myocardial injury. Advances in clinical chemistry 1994; 31: 63-98.

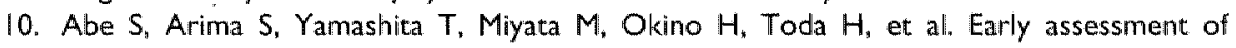
reperfusion therapy using cardiac troponin T. J Am Coll Cardiol 1994; 23: 1382-9.

11. Mair J. Wagner I, Jacob G. Lechleitner P, Dienstl F, Puschendorf B, et al. Different time courses of cardiac contractile proteins after acute myocardial infarction. Clin Chim Acta 1994; 231: 47-60.

12. Remppis A, Scheffold T, Karrer $O$, Zehelein J. Hamm $C$, Grunig $\mathbb{E}_{4}$ et al. Assessment of reperfusion of the infarct zone after acute myocardial infarction by serial cardiac troponin $T$ measurements in serum. Br Heart J 1994; 71: 242-8.

13. Lavin F, Kane M, Forde A, Gannon F, Daly K. Comparison of five cardiac markers in the detection of reperfusion after thrombolysis in acute myocardial infarction. $\mathrm{Br}$ Heart \1995: 73: $422-7$.

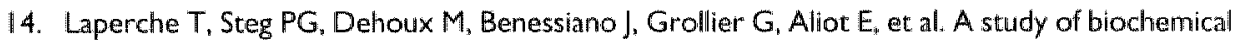
markers of reperfusion early after thrombolysis for acute myocardiall infarction. The PERM Study Group. Prospective Evaluation of Reperfusion Markers. Circulation 1995; 92: 2079-86.

15. Apple FS, Woss E, Lund L, Preese L, Berger CR, Henry TD. Cardiac troponin, CK-MB and myoglobin for the early detection of acute myocardial infarction and monitoring of reperfusion following thrombolytic therapy. Clin Chim Acta 1995; 237: 59-66.

16. Mair J. Artner-Dworzak E, Lechleitner $P$. Schmidt J. Wagner I, Dienstl $F$, et al. Cardiac troponin $T$ in diagnosis of acute myocardial infarction. Clin Chem 1991; 37: 845-52.

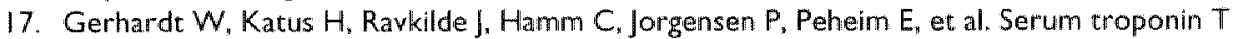
in suspected ischemic myocardial injury compared with mass and catalytic concentration of serum creatine kinase isoenzyme MB. Clin Chem I991; 37: 1405-9.

18. Remppis A, Scheffold T. Gireten J. Haass M, Greten T, Kubler W, et al Intracellular compartmentation of troponin T: release kinetics after global ischemia and calcium paradox in the isolated perfused rat heart. $\|$ Mol Cell Cardiol 1995; 27: 793-803. 
19. Kragten JA, Hermenis WT, Van Dieijen-Visser MP. Cardiac troponin T release into plasma after acute myocardial infarction: only fractional recovery compared with enzymes. Ann Clin Biochem 1996; 33: 314-23.

20. Willems GM, Visser MP, Krill MTA. Hermens WT. Quantitative analysis of plasma enzyme levels based on simultarieous determination of different enzymes. Cardiovasc Res 1982; 16: $\|20-3\|$.

21. Hermens WT, Van der Veen FH, Willems GM, Mullers-Bouman ML, Schrijvers-van Schendel A, Reneman RS. Complete recowery in plasma of enzymes lost from the heart after permanent coronary occlusion in the dog. Circulation 1990; 81:649-59.

22. Katus HA, Remppis A, Looser S, Hallermeier K, Scheffold $\pi$, Kubler W. Enzyme linked immuno assay of cardiac troponin $T$ for the detection of acute myocardial infarction in patients. J Mol Cell Cardiol 1989; 21: 1349-53.

23. Wisser MP, Krill MTA, Willems GM. Hermens WT. Selection of a suitable model for the plasma clearance and distribution of cardiac enzymes in the dog. Cardiovasc Res 1981; 15: $35-42$.

24. Van Kreel BK, Van der Veen FH, Willems GM, Hermens WT. Circulatory models in assessment of cardiac enzyme release in dogs. Am J physiol 1993; (Heart Circ Vol 33): H747-H54.

25. Hermens W. Willems G, Visser M. Quantification of circulating proteins. The Hague: Martinus Nijhoff Publishers, 1982.

26. Roberts $R$. Enzymatic estimation of infarct size. Thrombolysis induced its demise: will it now rekindle its renaissance? Circulation 1990; 81:707-10

27. Van der Veen FH, Hermens WT, Willems GM. Schrijvers-van Schendel A, Mullers-Boumans ML, Reneman RS. Time course of cellular enzyme release in dog heart injury. Circ Res 1990; 67: 1257-66.

28. Kragten JA, Van Nieuwenhoven FA, Van Dieijen-Visser MP, Theunissen PHMH, Hermens WT, Glatz JFC. Distribution of myoglobin and fatty acid binding protein in human cardiac autopsies. Clin Chem 1996; 42: 337-8.

29. Van der Laarse A, Kerkhof PLM, Serruys PW. Hermens WT, Verheugt FWA, Bar FW, et al. Relation between infarct size and left ventricular performance assessed in patients with first acute myocardial infarction randomized to intracoronary or to conventional therapy. Am J Cardiol 1988; $61: 1-7$.

30. Bhayana V. Henderson A. Biochemical markers of myocardial damage. Review. Clin Biochem 1995: 28: 1-29.

31. Burlina A, Zaninotto M. Secchiero S, Rubin D. Accorsi F. Troponin $T$ as a marker of ischemic myocardial injury. Clin Biochem 1994: 27: 113-21.

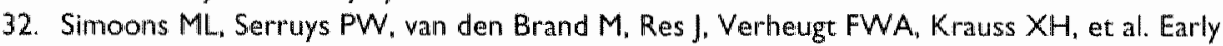
thrombolysis in acute myocardial infarction: Limitation of infarct size and improved survival. IAm Coll Cardiol 1986; 7: 717-28.

33. De Zwaan C. Willems GM, Vermeer F, Res J, Verheugt FWA, Van der Laarse A, et al. Enzyme tests in the evaluation of thrombolysis in acute myocardial infarction. Br Heart J 1988; 59: 175-83.

34. Anderson JL, Marshall HW, Askins JC, Lutz JR, Sorensen SG. A randomized trial of intravenous and intracoronary streptokinase in patients with acute myocardial infarction. Circulation $1984 ; 70: 606-18$.

35. Van de Werf F, Arnold A. For the European Cooperative Study Group for recombinant tissue type plasminogen activator: intravenous tissue plasminogen activator and size of infarct, left ventricular function and survival in acute myocardial infarction. Br. Med J 1988; 297:1374-9. 
36. Clark GL, Robinson A.K, Gnepp DR, Roberts R, Sobel BE. Effects of lymphatic transport of enzyme on plasma creatine kinase time-activicy curves after myocardial infarction in dogs. Circ Res 1978; $43: 162-9$.

37. Bleifeld W, Mathey $D_{n}$ Hanrath P, Buss H, Effert S. Infarct size estimated from serial creatine phosphokinase in relation to left wentricular dynamics. Circuation 1977; 55: 303-11.

38. Grande $P_{\text {, Hansen }} B F$, Christiansen $C$, Naestoft $J$. Estimation of acute myocardial infarct size in men by serum CK-MB measurements. Circulation 1982; 65: 756-64.

39. Hackel DB, Reimer KA, Ideker RE, Mikat EM, Hartwell TD, Parker CB, et al. Comparison of enzymatic and anatomic estimates of myocardial infarce size in man. Circulation 1984: 70: 824-35.

40. Jansen DE, Corbett JR, Wolfe CL, Lewis SE, Gabliani G, Filipchuk N, et al. Quantification of myocardial infarction: a comparison of single photon-emission computed tomography with pyrophosphate to serial plasma MB-creatine kinase measurements. Circulation 1985; 72:327-33.

41. Morrison J, Coromilas J, Munsey D, Robbins M, Zema M, Chiaramida S, et al. Correlation of radionuclide estimates of myocardial infarction size and release of creatine kinase-MB in man. Circulation 1980; 62:277-87. 
Chapter 4

\section{Distribution of myoglobin and fatty acid- binding protein in human cardiac autopsies}

Significance for the assessment of tissue injury from data on plasma protein concentrations

Johannes A. Kragten, Frans A. van Nieuwenhoven, Marja P. van Dieijen-Visser, Paul H.M.H. Theunissen, Wim. Th. Hermens and Jan F.C. Glatz

Clinical Chemistry 1996; 42: 337-8 


\section{Summary}

\section{Background}

Myoglobin $(\| 8 \mathrm{kDa})$ and fatty acid-binding protein (FABP, $15 \mathrm{kDa}$ ) are lowmolecular mass cytoplasmic proteins that are considered useful biochemical markers for early detection or exclusion of acute myocardial infarction and also for the estimation of the extent of acute myocardial infarction. For a quantitative assessment of myocardial tissue damage from the plasma myoglobin or FABP concentrations, it is required that variations in cardiac tissue content among individuals be small. Therefore, we examined both intra- (transmural) and interindividual variations in myoglobin and FABP content in heart tissue obtained at autopsy. The results were compared with variations in cardiac tissue content of the established infarct size marker $\alpha$-hydroxybutyrate dehydrogenase $(\mathrm{HBDH})$ or lactate dehydrogenase $(\mathrm{LDH}$; both $\mathrm{EC}$ I.I.1.27, $136 \mathrm{kDa}$ ), which are known to be remarkably stable on autopsy.

\section{Methods and results}

Enzyme and protein contents per gram wet weight of cardiac tissue were measured in epi-, mid- and endocardial samples of the left ventricles of 14 patients who died from causes other than acute myocardial infarction. Only patients with a heart mass $<450 \mathrm{~g}$ were included in the analysis. Mean cardiac tissue contents of $\mathrm{LDH}, \mathrm{HBDH}$, myoglobin and FABP were $397 \mathrm{U} / \mathrm{g}, 161 \mathrm{U} / \mathrm{g}, 2.79 \mathrm{mg} / \mathrm{g}$ and $0.57 \mathrm{mg} / \mathrm{g}$, with overall variations of $14.5 \%, 15.2 \%, 25.3 \%$ and $15.4 \%$. For all four markers no significant transmural gradients were found and tissue content was not related to the age of the individuals or autopsy delay. Differences between individuals were significant and we found a significant negative correlation between heart mass and cardiac tissue content for all four markers.

\section{Conclusions}

We found that variation in cardiac tissue content is comparable with the variation in cardiac tissue LDH or $\mathrm{HBDH}$ content, enzymes known to be stable at autopsy. Part of the variation in the present study is introduced by variation in heart weight. Variations in myoglobin content were greater, making FABP for reasons of both specificity and variation, more suitable for early assessment and early quantification of myocardial tissue damage.

\section{Introduction}

Now that thrombolytic treatment has become common therapy for patients with acute myocardial infarction, the necessity for earlier detection or exclusion of myocardial tissue damage has become extremely important. Upon muscle cell damage myoglobin, a low molecular mass ( $18 \mathrm{kDa}$ ) non-enzymatic protein abundantly 
present in the cytoplasm of both cardiac and skeletal muscle cells (1) is rapidly released into plasma and is considered a useful marker especially for early detection of myocardial infarction(1-4), of reinfarction(1,2) and for monitoring of cardiac reperfusion after thrombolytic therapy $(5-7)$. In the cell myoglobin transports oxygen from the musle cell membrane to the mitochondrion and is thought to function as a reservoir for oxygen (1). Recently FABP has been proposed as a similar, but more cardio-specific alternative for early detection of acute myocardial infarction(8-10). FABP is also a small cytoplasmic protein and serves as an intracellular carrier for fatty acids (11.12). Compared with high-molecular-mass cytoplasmic enzymes such as LDH, HBDH (136 $\mathrm{kDa}$ ) or creatine kinase (CK, EC 2.7.3.2; $80 \mathrm{kDa}$ ), myoglobin and FABP are more rapidly released into plasma, resulting in detectable increases in plasma as early as 2 hours after the onset of coronary occlusion(5,10). Although myoglobin and FABP are both present in heart as well as skeletal muscle their different contents in these tissues and simultaneous release upon muscle injury allows the plasma ratio of myoglobin/FABP to be used to discriminate myocardial (ratio $=5$ ) from skelecal muscle injury (ratio $=20-70)(13)$.

Although enzymes and proteins of intracellular origin that appear in plasma after cardiac tissue injury are used mainly for diagnostic purposes, interest is girowing in their application for estimation of infarct size(14-19). For a quantitative assessment of myocardial damage from plasma enzyme or protein concentrations it is assumed that variations in cardiac content among individuals are small. Variations in cardiac enzyme content have been extensively studied (20-24,27), but for cardiac proteins like myoglobin and FABP only preliminary data are available on the cardiac content of these proteins $(9,28)$. Therefore the present study was undertaken to investigate intra (transmural)- and interindividual variations in cardiac tissue content of both myoglobin and FABP. Influences of autopsy delay, differences between men and women and influences of age of the patient and heart weight were also investigated. For comparison, we also measured the activities of $\mathrm{LDH}$ and $\mathrm{HBDH}$, enzymes which are known to be remarkably stable on autopsy(20,21) and the latter being especially suitable for quantification of myocardial infarct size from plasma enzyme concentrations $(22,23)$. To allow comparison with the literature both $\mathrm{LDH}$ and $\mathrm{HBDH}$ were measured.

\section{Patients and methods}

\section{Autopsies}

Autopsies were performed in the Department of Clinical Pathology of the Hospital De Wever \& Gregorius in Heerlen on 14 patients who died from causes other than acute myocardial infarction. Only patients with a heart mass $<450 \mathrm{~g}$ " nonhypertrophic, were included in the study. For comparison, data of three hypertrophic patients (heart masses of 850,740 and $500 \mathrm{~g}$ ) were included. All procedures were approved by the Medical Ethical Committee of the Hospital. Samples were taken only 
when autopsy occurred within 24 hours post mortem. After death, the bodies were transported to the morgue within 3-6 hours and kept there at 40 $C$ until necropsy. Data on autopsy delay, heart weight and age of the patients are presented in Table 1 . At autopsy about $4 \mathrm{~cm}$ from the apex a transmural tissue sample of about $2 \mathrm{~g}$ was cut from the anterior wall of the left ventricle, bordering the septum.

Table I

Patient data

\begin{tabular}{llllll} 
Patient & Sex & Cause of death & $\begin{array}{l}\text { Heart } \\
\text { Weight } \\
(\mathbf{g})\end{array}$ & $\begin{array}{l}\text { Autopsy } \\
\text { delay } \\
\text { (h) }\end{array}$ & $\begin{array}{l}\text { Age } \\
\text { Years } \\
\text { (yr) }\end{array}$ \\
\hline I & f & hypovolemia & 260 & 24 & 80 \\
2 & f & carcinoma & 325 & 5 & 76 \\
3 & f & lung emphysema & 280 & 16 & 74 \\
4 & f & cerebrovascular accident & 330 & 21 & 20 \\
5 & f & cerebrovascular accident & 310 & 15 & 36 \\
6 & f & lung emphysema & 215 & 12 & 83 \\
7 & f & carcinoma & 380 & 3 & 90 \\
8 & f & carcinoma & 300 & 24 & 54 \\
9 & m & pneumonia & 380 & 4 & 74 \\
I0 & m & carcinoma & 370 & 7 & 74 \\
II & m & fibrosis of the lungs & 350 & 24 & 70 \\
I2 & m & sepsis & 430 & 22 & 75 \\
13 & m & pneumonia & 370 & 5 & 77 \\
14 & m & lung emphysema & 300 & 7 & 74 \\
Mean & & & $328^{*}$ & 14 & 68 \\
Median & & & 328 & 12 & 74 \\
SD & & & 57 & 8.2 & 19 \\
CV(\%) & & & 18 & 61 & 28
\end{tabular}

werom $\mathrm{CV}, 300 \pm 17 \%$ for women and $307 \pm 12 \%$ for ment

\section{Table 2}

Mean enzyme and protein content of left ventricular tissue obtained from 14 individuals

Parameter

$\mathrm{LDH}(\mathrm{U} / \mathrm{g})$

$\mathrm{HBDH}(\mathrm{U} / \mathrm{g})$

Myoglobin (mg/g)

FABP $(\mathrm{mg} / \mathrm{g})$

Myoglobin/FABP ratio
Mean $\mathrm{CV}(\%)$ Minimum Maximum Median

$\begin{array}{lllll}397 & 14.5 & 277 & 542 & 401 \\ 161 & 15.2 & 114 & 208 & 161 \\ 2.79 & 25.3 & 1.52 & 4.33 & 2.75 \\ 0.57 & 15.4 & 0.42 & 0.80 & 0.56 \\ 4.98 & 26.2 & 3.06 & 9.67 & 4.77\end{array}$




\section{Preparation of heart tissue samples}

Epicardial fat was removed from the tissue and, after gentle blotting to remove adhering moisture, a transmural sample of the left ventricle was divided into epi-, midand endocardial parts. Each sample was homogenized separately. Tissue samples were weighed and $0.5 \mathrm{~g}$ heart tissue was cut, homogenized (Ultraturrax, Janke and Kunkel, type (8-10) and sonicated (Sonorex Baudelin, type RK $102 \mathrm{H}, 120-240 \mathrm{~W}, 35 \mathrm{kHz}$ ). Homogenization, in 10 bursts, and sonication, in five 60s bursts, were performed in tubes kept on ice and containing $9.5 \mathrm{ml}$ ice-cold pasteurized plasma protein solution (4\%) (The Netherlands Red Cross Blood Transfusion Service, Amsterdam, The Netherlands). The suspension then was centrifuged at $2000 \times \mathrm{g}$ for 15 minutes and the supernatant liquid immediately stored at $-70^{\circ} \mathrm{C}$ until enzyme and protein analysis. In healthy dog hearts this procedure resulted in $10-12 \%$ overall variation in enzyme content, including 4-6\% intra-assay scatter for cardiac enzymes(24).

\section{Analytical techniques}

Activities of $\mathrm{LDH}$ and $\mathrm{HBDH}$ were determined spectrophotometrically using a centrifugal analyzer (Cobas Bio System, Hoffmann La Roche, Mijdrecht, The Netherlands). Commercially available test kits were used for LDH (Societé Française Biologie Clinique recommendation, pyruvate as a substrate, Unimate 3 Roche, art no 073657 0, Mijdrecht, The Netherlands) and HBDH (Deutsche Gesellschaft fur Klinische Chemie recommendation, optimized test from Boehringer, art no. I 442 589, Almere, The Netherlands). The HBDH assay is based on the specific activity of the myocardial isoenzymes $\mathrm{LDH}_{1}$ and $\mathrm{LDH}_{2}$ of lactate dehydrogenase toward $\alpha$-ketobutyrate instead of pyruvate, the natural substrate of LDH. Activities were determined at $37{ }^{\circ} \mathrm{C}$ and are expressed in micromoles of substrate converted per minute $(U)$, either per litre of plasma $(U / L)$ or per gram wet weight of tissue $(U / g)$.

For both $\mathrm{LDH}$ and $\mathrm{HBDH}$ interassay variations, as determined from repeated measurement of various contral sera were between $2 \%$ and $3.5 \%$.

Temperature correction coefficients were determined to allow comparison with data in the literature, which are mainly based on enzyme measurements at $25{ }^{\circ} \mathrm{C}$. Therefore, we measured $\mathrm{LDH}$ and $\mathrm{HBDH}$ activities in 15 serum samples at both $250^{\circ} \mathrm{C}$ and at $37 \circ \mathrm{C}$, yielding correction factors of 2.1 and 1.3 respectively.

Myoglobin was measured with a turbidimetric immunoassay, using the method of Delanghe et al. (25) (Turbiquant immunoassay, code OWNL, Behring, Hoechst Holland, Amsterdam, The Netherlands) on a TurbiTimer analyzer (Behring, Hoechst Holland). Dillutions of plasma and tissue samples were made in saline $(0.9 \% \mathrm{NaCl})$. The detection limit of the method was $50 \mathrm{mg} / \mathrm{L}$ and the measuring range $50-650 \mathrm{mg} / \mathrm{L}$. Internal quality control was performed using the human Apolipoprotein Control Serum CHD (Behring, OUPH 06/07, lotno. 063617, assigned value 95 (8I- $109 \mathrm{mg} / \mathrm{L}$ ). 
Measurement of this control serum on 22 successive days resulted in a mean concentration of $97.4 \mathrm{mg} / \mathrm{L}$ with $4.8 \%$ variation.

Fatty acid-binding protein was measured by a non-competitive immunosorbent assay of the antigen capture type (sandwich ELISA)(9). Samples were diluted with phosphate buffered saline ( $\mathrm{pH} 7.4$ ) containing $0.1 \%$ bovine serum albumin and $0.05 \%$ Tween-20. The detection limit of the assay was $0.5 \mathrm{mg} / \mathrm{L}$. The recovery (mean $\pm \mathrm{SD}$ ) of purified human heart FABP added in various quantities to control human plasma was $94 \pm 12 \%(n=1 \mid)$ and the interassay coefficient of variation was $6.5 \%$.

\section{Table 3}

Enzyme and protein content of epi-, mid- and endocardial samples of the left ventricle of 14 individuals

\begin{tabular}{lllllll} 
& \multicolumn{2}{c}{ Epicardial } & Mid & \multicolumn{3}{c}{ Endocardial } \\
Parameter & Mean & CV(\%) & Mean & $\mathrm{cV}(\%)$ & Mean & $\mathrm{CV}(\%)$ \\
\hline $\mathrm{LDH}(\mathrm{U} / \mathrm{g})$ & 391 & 13.7 & 410 & 16.1 & 389 & 13.8 \\
HBDH $(\mathrm{U} / \mathrm{g})$ & 160 & 14.9 & 165 & 16.7 & 158 & 14.6 \\
Myoglobin $(\mathrm{mg} / \mathrm{g})$ & 2.71 & 24.4 & 2.91 & 26.7 & 2.74 & 26.0 \\
FABP $(\mathrm{mg} / \mathrm{g})$ & 0.54 & 15.8 & 0.60 & 15.8 & 0.55 & 13.0 \\
Myoglobin/FABP ratio & 5.01 & 22.7 & 4.92 & 33.9 & 4.99 & 22.6
\end{tabular}

\section{Table $4 a$}

Effect of autopsy delay on cardiac tissue protein content

$\begin{array}{llll} & \begin{array}{l}\text { Mean for patients } \\ \text { with autopsy delay } \\ \leq 12 \text { hours }\end{array} & \begin{array}{l}\text { Mean for patients } \\ \text { with autopsy delay } \\ \mathbf{1} 12 \text { hours } \\ (\mathbf{n}=7)\end{array} & \text { Significance } \\ \text { Parameter } & 392 & 402 & \\ \text { LDH }(\mathrm{U} / \mathrm{g}) & 157 & 164 & \text { n.s. } \\ \mathrm{HBDH}(\mathrm{U} / \mathrm{g}) & 2.86 & 2.72 & \text { n.s. } \\ \text { Myoglobin }(\mathrm{mg} / \mathrm{g}) & 0.54 & 0.58 & \text { n.s. } \\ \text { FABP }(\mathrm{mg} / \mathrm{g}) & & & \text { n.s. }\end{array}$


Table $4 b$

Differences between men and women

\begin{tabular}{llll} 
Parameter & $\begin{array}{l}\text { Mean for women } \\
(\mathbf{n}=8)\end{array}$ & $\begin{array}{l}\text { Mean for men } \\
(\mathbf{n}=6)\end{array}$ & Significance \\
\hline LDH (U/g) & 402 & 390 & n.s. \\
HBDH (U/g) & 163 & 158 & n.s. \\
Myoglobin (mg/g) & 2.91 & 2.63 & $p<0.018$ \\
FABP (mg/g) & 0.59 & 0.53 & P $<0.009$
\end{tabular}

\section{Table $4 c$}

Effect of age of the patient on cardiac tissue protein content

\begin{tabular}{llll} 
& $\begin{array}{l}\text { Mean for } \\
\text { patient } \leq 74 \\
\text { years }(\mathbf{n = 8})\end{array}$ & $\begin{array}{l}\text { Mean for } \\
\text { patients }>\mathbf{7 4} \\
\text { years }(\mathbf{n = 6})\end{array}$ & Significance \\
\hline Parameter & 401 & 390 & \\
\hline $\mathrm{LDH}(\mathrm{U} / \mathrm{g})$ & 164 & 157 & n.s. \\
HBDH $(\mathrm{U} / \mathrm{g})$ & 2.76 & 2.83 & n.s. \\
Myoglobin $(\mathrm{mg} / \mathrm{g})$ & 0.58 & 0.55 & n.s. \\
FABP $(\mathrm{mg} / \mathrm{g})$ & & n.s. \\
\hline
\end{tabular}

\section{Table 4d}

Effect of heart weight on cardiac tissue protein content

Mean for patients Mean for patients Significance

$\begin{array}{llll}\text { Parameter } & \leq 345 \mathrm{~g}(\mathrm{n}=8) & >345 \mathrm{~g}(\mathrm{n}=6) & \\ \text { LDH (U/g) } & 414 & 374 & \mathrm{p}<0.0001 \\ \text { HBDH (U/g) } & 168 & 151 & \mathrm{p}<0.0001 \\ \text { Myoglobin (mg/g) } & 2.98 & 2.53 & \mathrm{p}<0.0003 \\ \text { FABP (mg/g) } & 0.59 & 0.53 & \mathrm{p}<0.0115\end{array}$


Figure 1

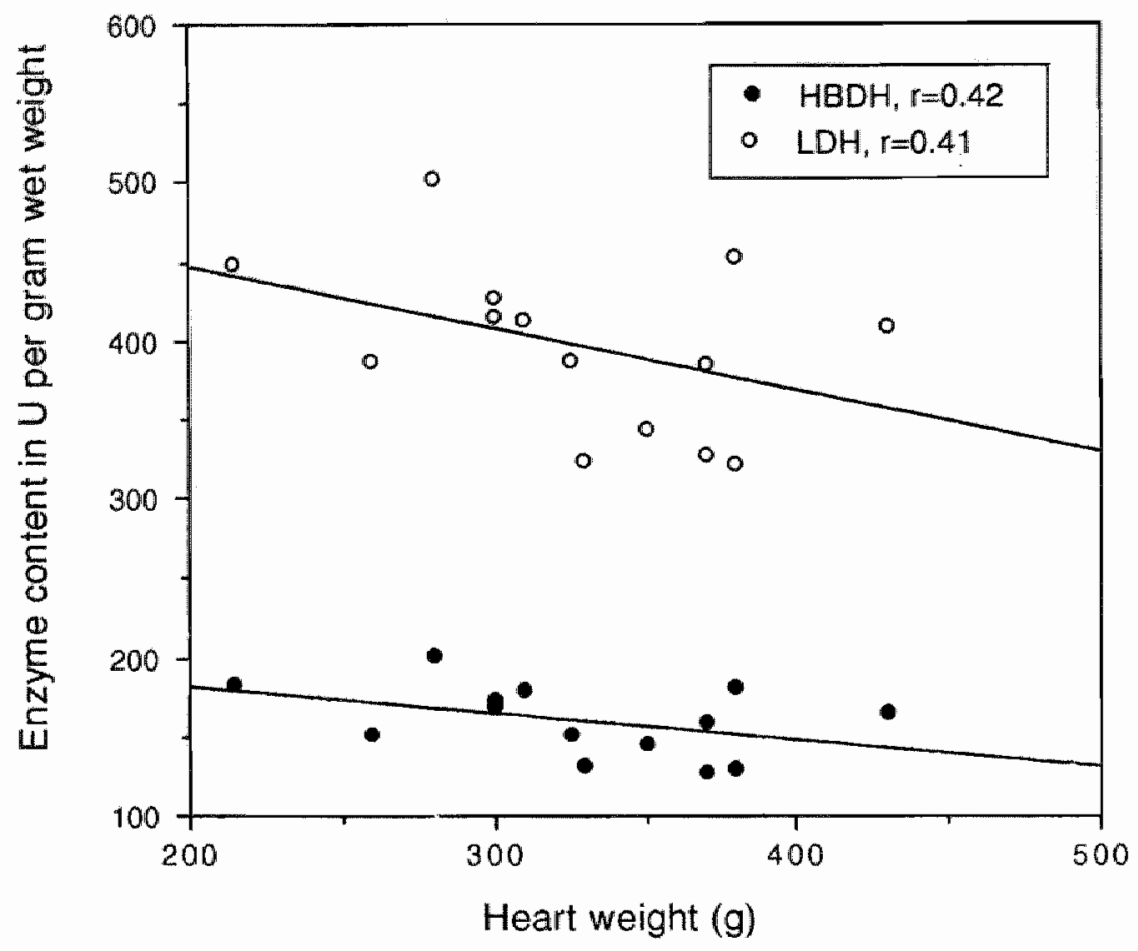

Relation between heart weight and $\mathrm{HBDH}$ and $\mathrm{LDH}$ content 
Figure 2

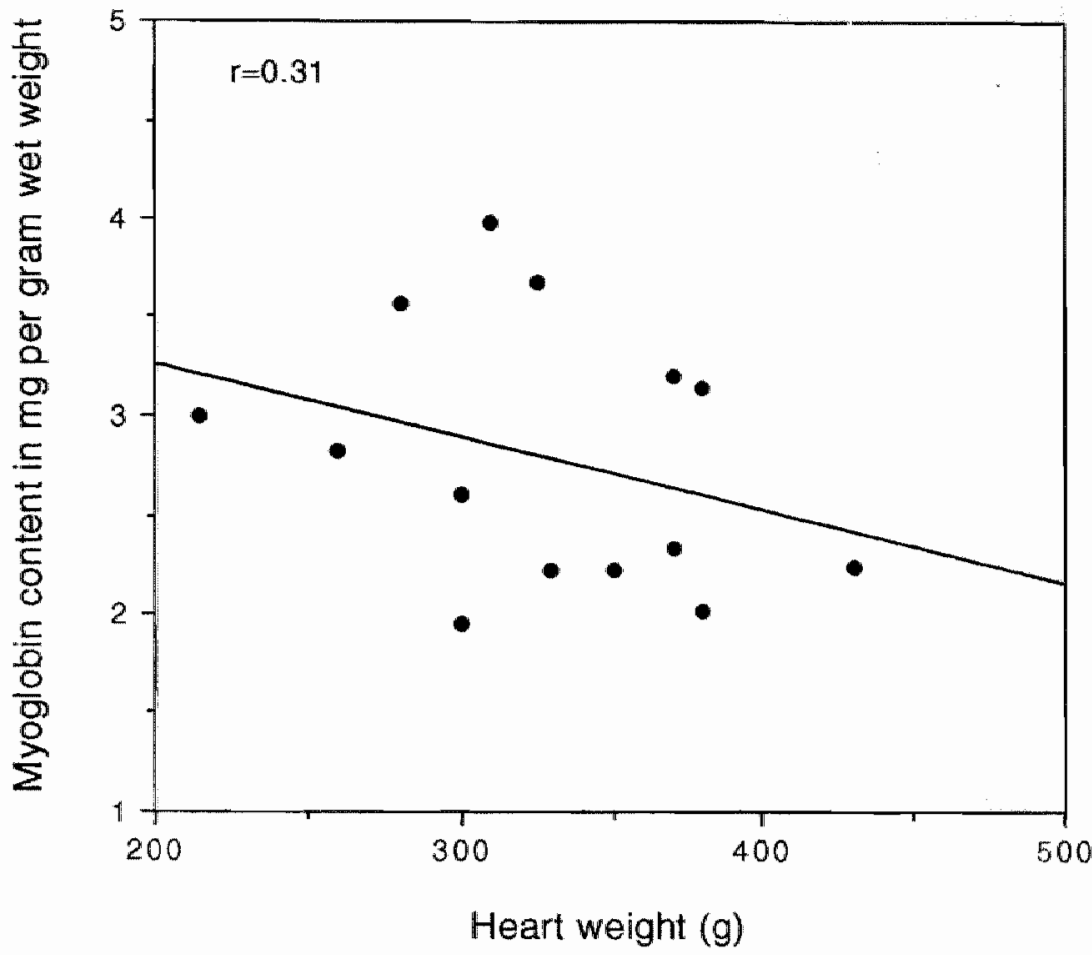

Relotion between heart weight and myoglobin content 


\section{Figure 3}

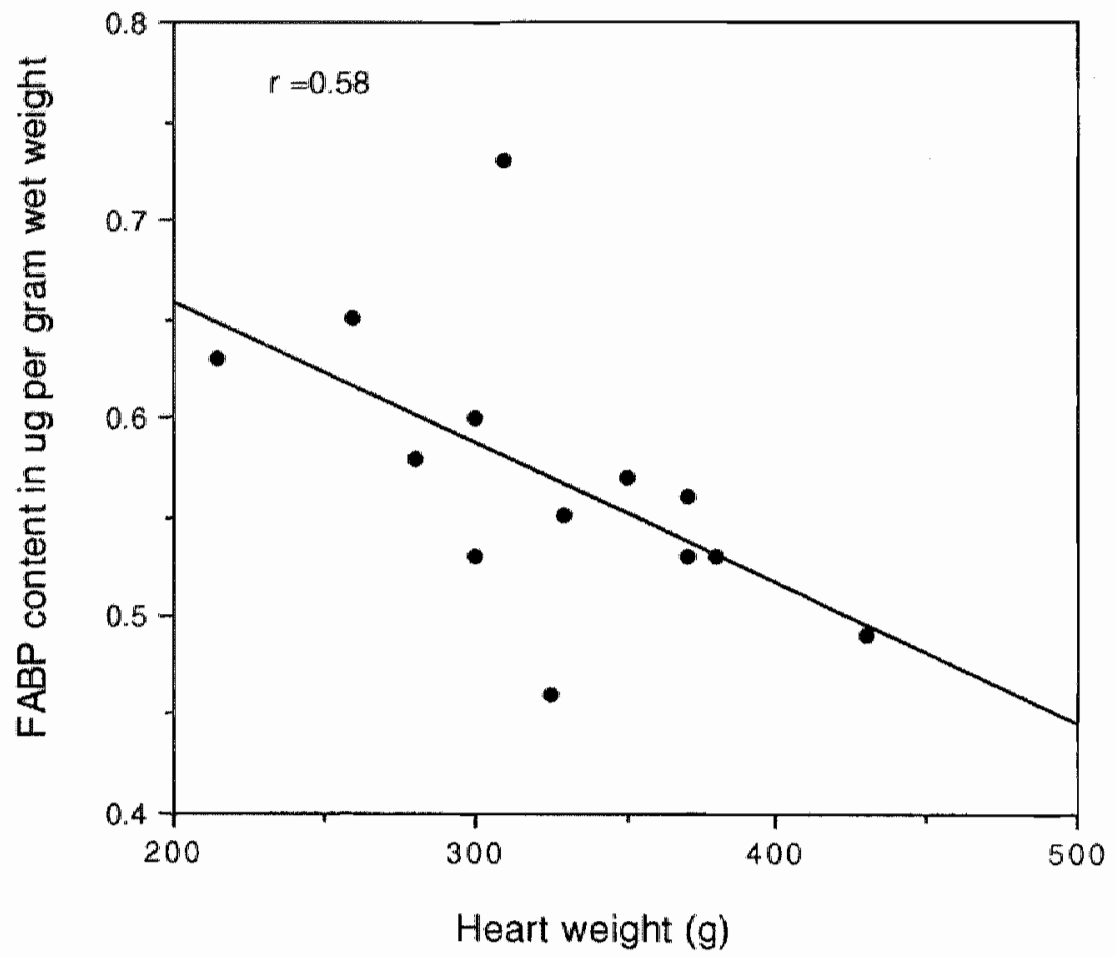

Relatian between heart weight and FABP content 


\section{Statistical analysis of data}

The BMDP statistical software program was used. Two different types of analysis were performed: (a) analysis of differences in enzyme or protein content among different individuals, influence of heart mass, age of the patient and autopsy delay and (b) analysis of transmural trends of myocardial enzyme or protein content in the left ventricle. The level of significance was set at $P<0.05$.

\section{Results}

Table 2 presents the overall means and variations in $\mathrm{LDH}, \mathrm{HBDH}$, myoglobin, and FABP cardiac tissue content for 42 samples obtained from the hearts of 14 individuals. The highest overall variation was found for myoglobin, whereas variations for $L D H, H B D H$ and FABP were smaller and comparable.

Interindividual differences in enzyme or protein content were significant for all four parameters.

Epi-, mid- and endocardial (transmural) differences were apparently not significant. The mean values and variations are presented in Table 3.

There was no significant relation between autopsy delay and $\mathrm{LDH}, \mathrm{HBDH}$, FABP or myoglobin content (Table 4a).

For myoglobin and FABP significantly $(P<0.018)$ higher cardiac tissue contents were found for women $(2.92 \mathrm{mg} / \mathrm{g})$ than for men $(2.63 \mathrm{mg} / \mathrm{g})$, (see Table $4 \mathrm{~b}$ ).

We found no influence of age of the patient on cardiac content of each of the different markers (Table 4c).

For all markers investigated tissue content is negatively correlated to heart mass and therefore to cardiac hypertrophy (Table $4 \mathrm{~d}$ and Figures $1-3$ ). In three patients with hypertrophic hearts (mean \pm SD, $696 \pm 176 \mathrm{~g}$ ), mean contents for FABP, myoglobin, $\mathrm{LDH}$, and $\mathrm{HBDH}$ were respectively $0.50 \pm 0.05 \mathrm{mg} / \mathrm{g}, 2.63 \pm 0.30 \mathrm{mg} / \mathrm{g}, 134$ $\pm 28 \mathrm{U} / \mathrm{g}$, and $330 \pm 62 \mathrm{U} / \mathrm{g}$. This indicates that the mean enzyme or protein content is about 10 to $15 \%$ lower than in nonhypertrophic hearts. 


\section{Discussion}

Enzymatic assessment of the extent of ischaemic myocardial injury has become routine clinical practice and has been applied successfully in the evaluation of thrombolytic therapy after acute myocardial infarction ${ }^{(29-33)}$. These studies demonstrated that the favorable effects of such therapy, namely preservation of myocardial function and reduced mortality, can be explained by limitation of infarct size and this has stimulated interest in the quantitative interpretation of enzymatic data (34). In order to express myocardial infarct size in $g$-eq healthy myocardium the cumulative plasma release of a cardiac marker (enzyme or protein) has to be divided by its content per gram wet weight of tissue. Accurate estimation of infarct size is only possible if variation in the tissue content of the marker used is small(14,19). In this way it has been demonstrated that different cardiac enzymes such as creatine kinase (CK) and $\alpha$-hydroxybutyrate dehydrogenase $(\mathrm{HBDH})$ produce approximately similar estimates of infarct size in g-eq of heart muscle per litre of plasma(16). Infarct size estimation from serial myoglobin observations in plasma has been investigated, but results were not expressed in g-eq heart tissue $(35)$. Recently it has been shown that FABP can be used as a plasma marker for estimation of myocardial infarct size in human(10). The rapid release of myoglobin and FABP into plasma might even allow a reliable measure of myocardial infarct size within 24 hours of acute myocardial infarction. However, this application must meet several conditions. Sufficient plasma samples have to be obtained during the first day of hospital admission and variations in tissue content should be small. The latter aspect has been investigated in the present study.

\section{Sources of scatter}

Comparison of absolute values for human tissue enzyme content with those reported in the literature is extremely difficult. Apart from the fact that enzyme contents are expressed in various manners, per gram wet weight, per gram dry weight or per $\mathrm{mg}$ total protein etc, large differences are also introduced by different assay conditions such as temperature, substrate concentrations, or addition of different activators. However, besides differences in absolute values of tissue enzyme or protein content, differences in reported variability are more important. Especially in the older literature the apparent biological scatter reported for most enzymes and organs is of the same order of magnitude as the scatter inherent of the assay procedures available at that time.

Another factor of importance in determination of tissue enzyme content is sample size. The use of small samples (biopsies of $10-50 \mathrm{mg}$ ) will tend to increase observed variability. In the present study $0.5 \mathrm{~g}$ wet weight of tissue was used, making the influence of sample size relatively small. 
The analytical variation was somewhat smaller for the enzymatic methods (2. $3.5 \%$ ) compared to the analytical variation of immunochemical methods used for analysis of myoglobin and FABP (5-6.5\%).

\section{Autopsies versus biopsies}

The long time intervals between death and necropsy in some patients obviously raise the question of stability of myocardial enzymes and proteins during autolysis. Indeed, rapid inactivation of CK and aspartate aminotransferase (AST), but not of $\mathrm{HBDH}$, has been reported in heart tissue of patients who died after acute myocardial infarction ${ }^{20}$. The stability of $\mathrm{HBDH}$ and $\mathrm{LDH}$ in human myocardium after death is a property of the myocardial isoenzymes $\mathrm{LDH}_{\|}$and $\mathrm{LDH}_{2}$, because rapid inactivation of $\mathrm{LDH}$ has been reported in autolysing skeletal muscle containing mainly $\mathrm{LDH}_{4}$ and $\mathrm{LDH}_{5}{ }^{(26)}$. Addition of pyridoxal-5-phosphate and mercaptoethanol diminishes the inactivation of CK and ASAT(21). However, in cardiac tissue for LDH and HBDH no special measures have to be taken to prevent autolysis or inactivation $(20,21,27)$. Van der Laarse ${ }^{(21)}$ compared myocardial enzyme activities in cardiac biopsies with those in cardiac tissue samples obtained at autopsy and observed only a slight effect of autolysis amounting $-1 \%$ to $-4 \%$ in the first 10 hours for $\mathrm{LDH}, \mathrm{HBDH}$ as well as AST. In autolysing human heart CK decreases more rapidly, $5-6 \%$ in the first 10 hours. Moreover, comparison of myocardial enzyme activities in biopsies with those in autopsies, the latter being corrected for autolysis induced inactivation, still revealed significant differences for CK and AST, but not for $\mathrm{HBDH}$ and $\mathrm{LDH}$ content.

Van der Laorse ${ }^{(21)}$ observed a HBDH content of $122 \mathrm{U} / \mathrm{g} \pm 12.3 \%$ determined at $25 \circ \mathrm{C}$. Using a temperature correction factor of 1.3 (see Methods) this results in a content of $159 \mathrm{U} / \mathrm{g} \pm 12.3 \%$, which is comparable with the value of $161 \mathrm{U} / \mathrm{g} \pm 15.2 \%$ as observed in the present study, determined at $37 \circ \mathrm{C}$. For $\mathrm{LDH} 166 \mathrm{U} / \mathrm{g} \pm 13.3 \%$ was found by Von der Laarse ${ }^{(21)}$ and using a temperature correction factor of 2.1 (see Methods), this results in a $\mathrm{LDH}$ content of $349 \mathrm{U} / \mathrm{g} \pm 13.3 \%$. This is a slightly lower, but still comparable with the $\mathrm{LDH}$ content of $397 \mathrm{U} / \mathrm{g} \pm 14.5 \% \mathrm{U} / \mathrm{g}$ observed in the present study.

In another study Van der Laarse et al. (27) compared LDH content in myacardial autopsies from nonhypertrophic $(n=33)$ and hypertrophic human hearts $(n=36)$ and found contents of $182 \mathrm{U} / \mathrm{g} \pm 12.6 \%$ at $25^{\circ} \mathrm{C}(382 \mathrm{U} / \mathrm{g}$ at $37 \circ \mathrm{C})$ in nonhypertrophic and of $155 \mathrm{U} / \mathrm{g} \pm 20 \%$ at $25{ }^{\circ} \mathrm{C}\left(326 \mathrm{U} / \mathrm{g}\right.$ at $\left.37{ }^{\circ} \mathrm{C}\right)$ in hypertrophic myacardium. In our study results from hypertrophic hearts were not included. The mean LDH content of 397 $\pm 14.5 \%$ found in our study corresponds very well with the value of $382 \mathrm{U} / \mathrm{g} \pm 12.6 \%$ found by Van der Laarse et al in nonhypertrophic hearts. 


\section{Transmural gradients}

It has been suggested that, even under normal conditions, a permanent adaptation to a restricted oxygen supply in the subendocardial layers results in a permanent metabolic adaptation(24,36). Lin et al. observed that activities of total LDH subunit and LDI slightly increased from atria and auricular appendages via the right ventricle to the left ventricle, while within the left ventricle no transmural gradients were observed(37). The latter is in accordance with the present results, where no transmural gradients were found for neither $L D H, H B D H$ nor for myoglobin and FABP. In a recent study we showed that, in samples taken from different sites in the heart, myoglobin and FABP slightly increase from the right ventricle, to the septum and to the posterior-, side- and anterior wall of the left ventricle(13), in accordance with the results described by $\mathrm{Lin}$ et al. for $\mathrm{LDH}^{(37)}$.

\section{Heart weight-dependent myocardial changes}

In adult human myocardium obtained post mortem Van der Laarse et al,(27) found that $\mathrm{LDH}$ and $\mathrm{LDH}_{\|, 2}$ subunit activities are negatively correlated to heart weight index. The present study confirms this finding and shows that not only for $L D H$, and $\mathrm{HBDH}$, but also for myoglobin and FABP the tissue content is negatively correlated to heart mass, and therefore to cardiac hypertrophy. Vork et al. also demonstrated lower FABP concentration per gram wet weight in spontaneously hypertensive rats, with 30-35\% higher ventricular mass, compared to Wistar Kyoto rats $(38)$.

\section{Age-dependent myocardial changes}

We found no influence of age of the patient and cardiac tissue content of the different markers. In the present study the age of the patients ranged from 20-86 years. In patients with congenital heart disease Van der Loarse et al.(27) found that CK content is negatively correlated to age, in patients younger than 34 years, whereas for $\mathrm{LDH}$ no relation between age of the patient and cardiac tissue content was found.

\section{Cardiac specificity of the different markers}

An increase in serum LDH activity is aspecific, because $L D H$ is present in nearly all organs and tissues. However, $\mathrm{HBDH}$ activity is based on the preferential activity of the isoenzymes $L D H_{1}$ and $\mathrm{LDH}_{2}$ toward $\alpha$-ketobutyrate instead of pyruvate, the natural substrate of $\mathrm{LDH}$. Although $\mathrm{LDH}_{1}$ and $\mathrm{LDH}_{2}$ are also present in substantial amount in erythrocytes, in the absence of hemolysis $\mathrm{HBDH}$ activity is rather specific for cardiac tissue damage. 
Van Nieuwenhoven et al.(13) recendy demonstrated that in intact human heart tissue, obtained from autopsy, the ratio of myoglobin and FABP was found to be $4.5 \pm 0.8$ (mean $\pm \mathrm{SD}$, five cases), while among various skeletal muscles this ratio was found to vary from 21 to 73 . They also found that over 24 hours after acute myocardial infarction the ratio of myoglobin over FABP in plasma was 4.4 1.4 (mean $\pm S D ; n=93$, nine patients), which is in agreement with the ratio found in heart tissue and the present study extended these observations. Therefore the ratio of the plasma or serum concentrations of myoglobin and FABP can be used to discriminate between myocardial and skeletal muscle cell injury.

\section{Conclusions}

We found that variation in cardiac tissue FABP content is comparable with the variation in cardiac tissue LDH or $\mathrm{HBDH}$ content, enzymes known to be stable on autopsy. Part of the variation in the present study is introduced by variation in heart weight.

Variations in myoglobin content were higher, compared to variations in FABP content, making FABP, for reasons of both specificity and variation more suitable for early assessment and early quantification of myocardial tissue damage. 


\section{References}

1. Kagen L. Myoglobin: methods and diagnostic uses. CRC Crit Rev Lab Sci $1978 ; 9: 273-302$.

2. Cairns $\int_{b}$ Missirlis $E_{8}$ Walker $W$. Usefulness of serial determinations of myoglobin and creatine kinase in serum compared for assessment of acute myocardial infarcton. Clin Chem 1983;29:469-73.

3. Delanghe $J R$, De Buyzere ML, Cluyse LP, Thierens HM, Clement DL. Acute myocardial Infarction size and myoglobin release into serum. Eur J Clin Chem Clin Biochem 1992;30: 823-30.

4. Mair J, Artner ${ }^{-D w o r z a k} E_{q}$ Lechleiter $P_{i}$ Morass B, Smidt J, Wagner I. Dienst $F$ and Puschendorf $B$. Early diagnosis of acute myocardial infarction by a newly developed rapid immunoturbidimetric assay for myoglobin. Br Heart ] 1992:68:462-8.

5. Ellis KA, Little Th, Masud Z, Liberman HA, Morris DC, Klocke FJ: Early noninvasive detection of successful reperfusion in patients with acute myocardial infarction. Circulation $1988 ; 78: 1352-7$.

6. Katus HA, Diederich KW, Scheffold T, Uellner M, Schwarz F, Kübler W: Non-invasive assessment of infarct reperfusion: the predictive power of the time to peak value of myoglobin, CKMB and CK in serum. Eur Heart J 1988;9:619-24.

7. Yamashita T. Abe S, Arima S, Nomoto K, Miyata M, Maruyama I, Toda H. Okino H.l. Atsuchi I, Tahara M, Nakao S, Tanaka H: Myocardial infarct size can be estimated from seriall plasma myoglobin measurements within 4 hours of reperfusion. Circulation 1993; 87:1840-9.

8. Tanaka $T$, Hirota $Y$, Sohmiya $K-I_{1}$ Nishimura $S$, Kawamura $K$. Serum and urinary heare fatty acid binding protein in acute myocardial infarction. Clin. Biochem 1991;24:195-201.

9. Kleine AH, Glatz JFC, Van Nieuwenhoven FA and Van der Vusse G]. Release of heart facty acid-binding protein into plasma after acure myocardial infarction in man. Mol Cell Biochem 1992; 116:155-62.

10. Glatz JFC, Kleine AH, van Nieuwenhoven FA, Hermens W Th, van Dieijen-Visser MP and van der Vusse G]. Fatty-acid-binding protein as a plasma marker for the estimation of myocardial infarct size in humans. Br Heart $\rfloor|994 ; 7|: \mid 35-40$.

II. Glatz JFC, van de Vusse GJ. Cellular fatty acid binding proteins: Current concepts and future directions. Mol Cell Biochem 1990:98:237-51.

12. Veerkamp $J H_{1}$ Peeters RA. Maatman RGHJ. Structural and functional features of different types of cytoplasmic fatty acid binding proteins. Biochem Biophys Acta 1991:1081:1-24.

13. Van Nieuwenhoven FA, Kleine AH, Wodzig KWH, Hermens WTh, Kragten JA, Maessen JG, Punt CD, Van Dieijen-Visser MP, Van der Vusse GJ and Glatz JFC. Discrimination between myocardial and skeletal muscle injury by assessment of the plasma ratio of myoglobin over fatty-acid binding protein. Circulation 1995;92:2848-54.

14. Willems GM, Visser MP, Krill MTA, Hermens WTh: Quantitative analysis of plasma enzyme levels based on simultaneous determination of different enzymes. Cardiovasc Res $1982 ; 16: 120-31$.

15. Van der Veen FH, Hermens WTh, Willems GM, Schrijvers-van Schendel A, MullersBoumans ML. Reneman RS: Time course of cellullar enzyme release in dog heart injury. Circ Res 1990; 67:1257-66.

16. De Zwaan Ch, Willems GM, Vermeer F, Res J. Verheugt FWA, Van der Laarse A, Simoons ML, Lubsen J. Hermens WTh: Enzyme tests in the evaluation of thrombiolysis in acute myocardial infarction. Br Heart J 198:8;59:175-83.

17. Anderson JL, Marshall HW. Askins JC, LuZz JR, Sorensen SG, Menlove RL, Yanowitz FG, Hagan $A D$ : A randomized trial of intravenous and intracoronary streptokinase in patients with acute myocandial infarction. Circulation 1984;70:606-18. 
18. Simoons ML, Serruys PW, Van den Brand M, Res \, Verheuge FWA, Krauss, XH, Remme W]. Bär $F$, de Zwaan $C h$, van der Laarse A, Vermeer $F$, Lubsen J: Early thrombolysis in acute myocardial infarction: Limitation of infaret size and improved survival. I Am Coll Cardiol 1986:7:717-28.

19. Hermens WTh, Van der Veen FH, Willems GM. Reneman RS: Enzymatic infarct size and its significance for evaluation of thrombolytic therapy after acute myocardial infarction (Letter to the Editor). Circulation 1990;81:1719-20.

20. Hermens WTh, van der Laarse $A$ and Witteveen SAG]. Enzymatic infarct sizing: Factors influencing the choice of the marker enzyme. In: Enzymes in Candiology Hearse DJ and de Leiris J, Eds., John Wiley and Sons, New York, 1979. pp 339-53.

211. Van der Laarse A, Dijkshoorn NJ. Hollaar L, Caspers T. The (iso)-enzyme activities of lactate dehydrogenase, alphahydroxybutyrate dehydrogenase, creatine kinase and aspartate aminotransferase in human myocardial biopsies and autopsies. Clin Chim acta 1980;104:381-9|

22. Hermens WTh, Van der Veen FH, Willems GM, Mullers-Boumans ML, Schrijvers- van Schendel A, Reneman RS: Complete recovery in plasma of enzymes lost from the heart after permanent coronary artery occlusion in the dog. Circulation 1990;8 1:649-59.

23. Van der Veen FH, Visser R, Willems GM. Kop-Klaassen B, Hermens WTh: Myocandial enzyme depletion in infarcted human hearts: "infarct size and equivalent tissue mass. Cardiovasc Res 1988;22: 611-19.

24. Visser MP, Krill MTA, Muijtjens AMMI, Willems GM, Hermens WTh. Distribution of enzymes in dog heart and liver. Significance for assessment of tissue damage from data on plasma enzyme activities. Clin Chem 1982;27:1845-50.

25. Delanghe J, Chapelle JP, Magdeleine EA and De Buyzere M. Quantitativeturbidimetric assay for determining myoglobin evaluated. Ann Clin Biochem 1991:28:474-9.

26. Schmidt E, Schmidt FW. Enzymmuster menschlicher Gewebe. Klin Wochenschr. 1960;38:957-62.

27. Van der Laarse A. Hollaar L, Vliegen HW, Egas JM, Dijkshoorn NJ, Cornelisse C], Bogers AJIC and Quaegebeur JM. Myocardial (iso)enzyme activities, DNA concentration and nuclear polyploidy in hearts of patients operated upon for congenital heart disease, and in normal and hypertrophic adult human hearts at autopsy. Eur J Clin lnvest 1989:19:192-200.

28. Van Nieuwenhoven FA, Kleine AH, Keizer HA, yan Dieijen-Visser MP, van der Vusse Gl and Glatz JFC. Comparison of myoglobin and fatry acid-binding protein as plasma markers for muscle damage in man. Eur J Physiol 1992;42 ll:R40.

29. The ISAM Study Group: A prospective trial on intravenous streptokinase in acute myocardial infarction. N Engl J Med 1986;314:1465-71\|

30. Simoons ML, Serruys PW, Van den Brand M. Res J. Verheugt FWA, Krauss XH, Remme W], Bär $F$, de Zwaan Ch, wan der Laarse $A$, Vermeer F, Lubsen J: Early thrombolysis in acute myocardial infarction: Limitation of infarct size and improved survival. I Arn Coll Cardiol 1986:7:717-28.

31. Van der Werf F, Arnold AER for the European Cooperatiwe Study Group for recombinant tissue type plasminogen activator: Intrawenous tissue plasminogen activator and size of infarct, left ventricular function and survival in acute myocardial infarction. Br Med J 1988; 297:1374-79.

32. The Thrombolysis Early in Acute Heart Attack Study Group: Very early thrombolytic therapy in suspected acute myocardial infarction. Am J Cardial 1990;65:401-7.

33. Karagounis L, Sorensen SG, Menlove RL, Moreno F. Andersen JL: Does thrombolysis in myocardial infarction (TIMI) perfusion grade 2 represent a mostly patent artery or a mostly occluded artery? Enzymatic and electrocardiographic evidence from the TEAM-2 study. J Am Coll Cardiol 1992;19:1-10. 
34. Roberts R.Enzymatic estimation of infarct size: Thrombolysis induced its demise: Will it now relkindle its renaissance? Circullation 1990;81:707-10.

35. Groth T. Hakman M and Sylven C. Size estimation of acute myocardial infarction from serial myoglobin observations with due consideration of individual differences in basic kinetics. Scand J Clin Lab Invest $1984 ; 44: 65-78$.

36. Lundsgaard-Hansen $P$, Meyer $C$ and Riedwyl $H$. Transmural gradients of glycolycic enzyme activities in left ventricular myocardium. The normal state. Pflugers Archiw 1967:297:89106.

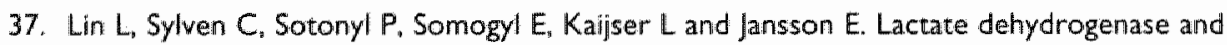
its isoenzyme activities in different parts of the normal human heart. Cardiovasc Res $1989 ; 23: 601-6$.

38. Vork MM, Trigault N, Snoeckx LHEH, Glatz JFC and Van der Vusse GJ. Heterogeneous distribution of fatty acid-binding protein in hearts of wistar kyoto and spontaneously hypertensive rats. I Moll Cell Cardiol 1992;24:317-21. 
Chapter 5

Estimation of myocardial infarct size from plasma myoglobin or fatty acid-binding protein. Influence of renal function

K. Will H. Wodzig, Johannes A. Kragten, Wim Th. Hermens, Jan F. C. Glatz and Marja P. van Dieijen-Visser

Eur. J. Clin. Chem. Clin. Biochem. 1997; 35: 191-8 


\section{Summary}

\section{Background}

Myoglobin ( $\left.M_{r} 18000\right)$ and fatty acid-binding protein (FABP) $\left(M_{r} 15000\right)$ are low-molecular-mass cytoplasmic proteins that are considered useful biochemical markers for early detection or exclusion of acute myocardial infarction, and also for early estimation of infarct size. As each of these proteins shows renal clearance, we studied the influence of renal function on the estimation of infarct size from their plasma concentration curves. For this, infarct size estimated from plasma myoglobin or FABP release curves was compared with that estimated with the established infarct size markers hydroxybutyrate dehydrogenase $(\mathrm{HBDH})$ and creatine kinase $(\mathrm{CK})$, which are not influenced by changes in renal function. The discordance between infarct size estimates was related to renal function.

\section{Methods}

Creatine kinase (CK; EC 2.7.3.2), hydroxybutyrate dehydrogenase ( $\mathrm{HBDH} ; \mathrm{EC}$ 1.I.1.27), myoglobin, FABP and creatinine were assayed serially in plasma samples obtained frequently and for at least 72 hours after the start of thrombolytic therapy in 20 patients with acute myocardial infarction. Cumulative release (Q) of the different cardiac markers was calculated by using a two-compartment model for circulating proteins. Mean tissue contents of $156 \mathrm{U} / \mathrm{g}$ for $\mathrm{HBDH}, 2163 \mathrm{U} / \mathrm{g}$ for $\mathrm{CK}$, $2.79 \mathrm{mg} / \mathrm{g}$ for myoglobin and $0.57 \mathrm{mg} / \mathrm{g}$ wet weight for $\mathrm{FABP}$, were used to express infarct size in gram-equivalents of healthy myocardium per litre of plasma ( $g$-eq/L). Mean plasma creatinine was obtained by averaging the creatinine concentrations measured in all plasma samples taken during the first 24 hours after acute myocardial infarction.

\section{Results}

A relation was found between the mean plasma creatinine concentration during the first 24 hours after acute myocardial infarction and the discordance between infarct size estimated from cumulative HBDH release, compared to infarct size estimated from cumulative myoglobin or FABP release. For patients with mean plasma creatinine concentrations within the reference interval for creatinine (group $1, n=15$ ) a good agreement was found between infarct size estimated from myoglobin or FABP plasma curves and that estimated with either $\mathrm{HBDH}$ or $\mathrm{CK}$. However, for patients with a mean creatinine concentration above the upper reference limit (group $2, n=5$ ), infarct size calculated from plasma myoglobin or FABP release curves was markedly overestimated, especially for larger infarcts. 


\section{Conclusion}

Estimation of infarct size from serial plasma myoglobin or FABP concentrations is possible in the first $\mathbf{2 4}$ hours after the onset of symptoms, but only in patients with normal renal function, as estimated from plasma creatinine concentrations. 


\section{Introduction}

The serial measurement of cardiac proteins in blood plasma is frequently used for diagnosing acute myocardial infarction and also for infarct size estimation. Since the introduction of thrombolytic treatment the necessity for earlier detection or exclusion of acute myocardial infarction has become extremely important. Apart from early detection of acute myocardial infarction, an earlier estimation of infarct size would be of value to determine patient prognosis in an earlier stage, or for evaluating in clinical studies the effect of therapeutic interventions on infarct size.

Myoglobin is a low-molecular-mass $\left(M_{r} 18000\right)$ non-enzymatic protein, abundantly present in the cytoplasm of both cardiac and skeletal muscle cells $(1,2)$. Upon muscle cell damage myoglobin is rapidly released into plasma and is considered a useful marker especially for early detection of myocardial infarction (3-5), for detection of reinfarction ${ }^{(2.3)}$ and for monitoring of cardiac reperfusion after thrombolytic therapy ${ }^{(6-8)}$.

Another small cardiac protein, heart-type fatty acid-binding protein (FABP; $\left.M_{r} 15000\right)$ has also been proposed as an early marker for acute myocardial infarction (9-11). FABP is a cytoplasmic protein that serves as an intracellular carrier for fatty acids $(\| 2,13)$. Compared with high molecular-mass cytoplasmic enzymes such as hydroxybutyrate dehydrogenase $\left(\mathrm{HBDH}, \mathrm{EC}\right.$ 1.1.1.27; $\left.\mathrm{M}_{\mathrm{r}}=136000\right)$ or creatine kinase $\left(C K, E C\right.$ 2.7.3.2; $\left.M_{r}=80000\right)$, myoglobin and $F A B P$ are more rapidly released into plasma, resulting in detectable increases in plasma as early as 2 hours after the onset of coronary occlusion ${ }^{(6,11)}$. Although myoglobin and FABP are both present in heart as well as skeletal muscle cells, their different contents in these tissues and simultaneous release upon muscle injury allows the plasma ratio of myoglobin/FABP to be used to discriminate myocardial $($ ratio $=4-6)$ from skeletal muscle injury (ratio= 20-70) (14, 15).

For quantitative assessment of myocardial tissue damage from the plasma myoglobin or FABP curve, the calculated cumulative release per litre plasma has to be divided by myoglobin or FABP content per gram wet weight of tissue, so that myocardial injury can be expressed in gram equivalents of healthy myocardium per litre plasma (infarct size). To do so, it is required that the variations in cardiac tissue content among individuals be small. We demonstrated that the inter-individual variations in cardiac tissue content of FABP and $\mathrm{HBDH}$ (about 15\%) are smaller compared to the inter-individual variation of myoglobin content (about $25 \%$ ) ${ }^{(16)}$.

In a recent study on the estimation of infarct size from plasma FABP concentrations it was shown that the cumulative FABP release, expressed as gram equivalents of healthy myocardium per litre plasma, yielded a comparable although slightly higher infarct size when estimated from FABP compared to that estimated from HBDH plasma curves (11).

For myoglobin, it has been demonstrated that plasma levels are inversely related to the glomerular filtration rate $(r=0.62)$ and linearly related to serum creatinine $(r=0.63)$ in patients with renal disease (17). For FABP elevated plasma levels have also been found in case of renal insufficiency ${ }^{(14,18)}$. As a consequence, individual 
differences in renal function, or impairment of renal function after acute myocardial infarction, may complicate the quantitative use of myoglobin and also FABP.

Therefore, the aims of the present study were

(1) to compare infarct size, estimated from plasma release curves of lowmolecular-mass markers like myoglobin and FABP, with infarct size estimated with the established infarct size markers $\mathrm{HBDH}$ and $\mathrm{CK}$,

(2) to examine the influence of changes in renal clearance of myoglobin or FABP on infarct size estimation. For the latter the discordance between infarct size estimated from $\mathrm{HBDH}$ release, compared to infarct size estimated from myoglobin or FABP release $\left(Q_{\text {myoglobin }} / Q_{H B D H}\right.$ or $\left.\mathrm{Q}_{\mathrm{FABP}} / \mathrm{Q}_{\mathrm{HBDH}}\right)$, was related to the mean plasma creatinine concentration during the first 24 hours after acute myocardial infarction.

\section{Patients and Methods}

\section{Patients}

Patients ( 17 men and 3 women, Table I) presented at the Department of Cardiology of the Hospital De Wever \& Gregorius in Heerlen with chest pain and ST segment elevation typical of acute myocardial infarction within 6 hours after the onset of symptoms, were treated with thrombolytic therapy. First, $160 \mathrm{mg}$ of acety/salicylic acid (aspirin) was given (unless already given by a general practitioner or ambulance nurses), followed by thrombolytic therapy, which consisted of 1.5 million units of streptokinase, given by infusion in $40 \mathrm{~min}$. Four hours after starting thrombolytic therapy heparin was given, 12500 units subcutaneous, every $\$ 2$ hours, for 5 days. All procedures followed were approved by the Medical Ethical Committee of the Hospital.

All patients included had given informed consent. Their mean age was $61 \pm 7.7$ years (mean $\pm S D$, median 60 and range $49-78$ years) and the mean treatment delay was $2.1 \pm 1.2 \mathrm{~h}$ (mean $\pm \mathrm{SD}$, median 1.8 and range $0.7-5.3 \mathrm{~h}$ ). Patients with increased risk of bleeding, previous coronary bypass surgery or $\mathrm{Q}$-wave indicated infarction in the same location, severe hepatic disease, or inability to give informed consent were excluded from the study.

Venous blood samples of $10 \mathrm{ml}$ were obtained immediately before starting thrombolytic therapy, and 1, 2, 3, 4, 5, 6, 8, 10,14, 18, 22, 28, 34, 46, 58, and 70 hours later. Exact sampling times were recorded and expressed as time after the onset of symptoms. Most samples were taken from indwelling catheters and care was taken to prevent haemolysis. Contamination with infused solutions was prevented by using a second catheter for infusion purposes. Blood was collected in pre-distributed and labelled tubes, containing dry heparin to prevent clotting, and was taken to the laboratory immediately. Plasma samples, obtained after routine centrifugation, were stored at $-70^{\circ} \mathrm{C}$ until analysis. 


\section{Assays}

Activities of $\mathrm{CK}$ and $\mathrm{HBDH}$ were measured spectrophotometrically at $37 \circ \mathrm{C}$ using a centrifugal analyzer (Cobas Bio System, Hoffmann La Roche, Mijdrecht, The Netherlands). Commercially available testkits were used for CK (CK-Nacetylcysteine, International Federation of Clinical Chemistry [IFCC] recommendation, Unimate 3 Roche, art no 073647 3) and $\mathrm{HBDH}$ (Deutsche Gesellschaft für Klinische Chemie [DGKC] recommendation, optimized test from Boehringer, art no. I 442 589, Almere, The Netherlands). The HBDH test is based on preferential catalytic activity of the myocardial is oforms $\mathrm{LDH}_{\|}$and $\mathrm{LDH}_{2}$ of lactate dehydrogenase toward $\alpha$-ketobutyrate instead of pyruvate, the natural substrate of $\mathrm{LDH}$. Activities were determined at $37{ }^{\circ} \mathrm{C}$ and were expressed in micromoles of substrate converted per minute $(U)$, either per litre of plasma $(U / L)$ or per gram wet weight of tissue $(\mathrm{U} / \mathrm{g})$.

Myoglobin was measured with a turbidimetric immunoassay, using the method of Delanghe et al. (19) (Turbiquant immunoassay, code OWNL, Behring, Hoechst Holland, Amsterdam, The Netherlands) on a TurbiTimer analyzer (Behring, Hoechst Holland). Dilutions of plasma and tissue samples were made in saline $(9 \mathrm{~g} / \mathrm{L} \mathrm{NaCl})$. The detection limit of the method was $50 \mu \mathrm{g} / \mathrm{L}$ and the measuring range $50-650 \mu \mathrm{g} / \mathrm{L}$. Internal quality control was performed using the human Apolipoprotein Control Serum CHD (Behring, OUPH 06/07, lotno. 063617 , assigned value $95(81-109 \mu \mathrm{g} / \mathrm{L})$. Measurement of this control serum on 22 successive days resulted in a mean concentration of $97.4 \mu \mathrm{g} / \mathrm{L}$ with $4.8 \%$ variation.

Fatty acid-binding protein was measured by a direct (one-step) noncompetitive immunosorbent assay of the antigen capture type (sandwich ELISA) as described by Wodzig et al. (20). Samples were diluted with phosphate buffered saline $(\mathrm{pH} 7.4$ ) containing $\mathrm{I} \mathrm{g} / \mathrm{L}$ bovine serum albumin and $0.5 \mathrm{~g} / \mathrm{L}$ Tween-20. The detection limit of the assay was $0.2 \mu \mathrm{g} / \mathrm{L}$. The recovery (mean $\pm \mathrm{SD}$ ) of purified human heart FABP added in various quantities to control human plasma was $97 \pm 5 \%(n=12)$ and the intra- and inter-assay coefficient of variation were respectively $6.5 \%$ and $11 \%$.

Creatinine was analysed on a Beckman Synchron CX-7 system with Beckman reagents (testkit CREA 442760, Beckman Instruments Inc., Mijdrecht. The Netherlands). The method is based on a modified Jaffé method. In the reaction, creatinine combines with picrate in an alkaline solution to form a creatinine-picrate complex. The system monitors the change in absorbance at $520 \mathrm{~nm}$. Reference values were in men $71-110$ $\mu \mathrm{mol} / \mathrm{L}$, and in women 53-97 $\mu \mathrm{mol} / \mathrm{L}$.

\section{Calculation of cumulative protein release into plasma}

The cumulative release of enzyme activity per litre of plasma from the onset of acute myocardial infarction $(\mathrm{t}=0)$ up to time $\mathrm{t}, \mathrm{Q}(\mathrm{t})$, was calculated with the following expression for a two-compartment model: 


$$
Q(t)=C(t)+T E R \sigma_{0}{ }^{t} \exp [-E R R(t-\tau)] C(\tau) d \tau+F C R \int_{0}{ }^{t} C(\tau) d t
$$

The three terms are the protein concentration in plasma, the extravasated protein concentration and the concentration eliminated from plasma, all three expressed per litre of plasma. $C(t)$ is the plasma enzyme activity or protein concentration at time $t$, corrected by substraction of the normal steady-state values $C_{s}$. The fractional rate constants are for transcapillary escape (TER), extiavascular return (ERR) and catabolism (FCR) of activity. This two-compartment model has been validated in the $\operatorname{dog}(21,22)$. Values for $\mathrm{HBDH}$ and $\mathrm{CK}$ estimated in man are (23):

$$
\begin{aligned}
& \mathrm{FCR}_{\mathrm{HBDH}}=0.015 \mathrm{~h}^{-1}, \mathrm{FCR}_{\mathrm{CK}}=0.20 \mathrm{~h}^{-1}, \\
& T E R=0.014 \mathrm{~h}^{-1} \text { and } E R R=0.018 \mathrm{~h}^{-1} .
\end{aligned}
$$

If the first plasma sample was obtained within 3 hours after the onset of symptoms, the corresponding enzyme activities were used for $C_{s}$. In the remaining cases, fixed mean values of $100 \mathrm{U} / \mathrm{L}$ and $1 / 2 \mathrm{U} / \mathrm{L}$ were used for $C K$ and $\mathrm{HBDH}$, respectively.

\section{Calculation of cumulative release of myoglobin and FABP into plasma}

Intravenously injected radiolabeled myoglobin shows rapid initial disappearance from plasma with a half-life of $10-20 \mathrm{~min}{ }^{(24.25)}$. However, it is known that the process of radiolabelling may significantly alter the biophysical characteristics of myoglobin and may consequently disturb the estimation of the serum half-life. It was verified that the disappearance rate is not altered in patients with acute myocardial infarction (26). We used a two-compartment model for the calculation of the cumulative myoglobin and FABP release. Using data on glomerular filtration rates in elderly adults (50-60 years) ${ }^{(27)}$ and data on the extravasation and distribution of myoglobin ${ }^{(28 .}{ }^{29)}$, parameter values obtained for FABP and myoglobin were:

$$
\text { FCR } R_{\text {myoglobin }}=2.1 \mathrm{~h}^{-1}, \mathrm{FCR}_{\text {FABP }}=2.1 \mathrm{~h}^{-1}, \text { TER }=0.3 \mathrm{~h}^{-1} \text { and } E R R=0.1 \mathrm{~h}^{-1} \text {. }
$$

The high FCR values for FABP and myoglobin of course raise the question whether a one-compartment model, with extravasation neglected in comparison to clearance, would be sufficient for quantitative description of these proteins. However, as illustrated by the high value of $T E R=0.3 \mathrm{~h}^{-1}$ for $F A B P$ and myoglobin, versus $T E R=0.014 \mathrm{~h}^{-1}$ for $\mathrm{HBDH}$ and $\mathrm{CK}$, transcapillary exchange of these small proteins is also much larger than for the large enzyme molecules, and therefore has an appreciable influence, especially on early plasma kinetics. This prompted us to also use a two-compartment model for the small protein molecules. If the first plasma sample was obtained within 3 hours after the onset of symptoms, the corresponding concentrations were used for $\mathrm{C}_{\mathrm{s}}$. In the remaining cases, fixed mean values of $33 \mu \mathrm{g} / \mathrm{L}$ for myoglobin and $2 \mu \mathrm{g} / \mathrm{L}$ for fatty acid-binding protein were used. Samples with 
myoglobin concentrations below $50 \mu \mathrm{g} / \mathrm{L}$, the detection limit of the assay, were also indicated as $33 \mu \mathrm{g} / \mathrm{L}$, the mean reference value for myoglobin using a radioimmunoassay.

\section{Expression of myocardial injury in gram-equivalents of tissue per litre of plasma}

To express myocardial injury in gram-equivalents heart muscle per litre of plasma, the cumulative release of cardiac enzymes or proteins per litre of plasma was divided by the respective enzyme or protein content per gram wet weight of healthy myocardium. CK, HBDH, FABP and myoglobin contents per gram wet weight as determined in an earlier study of our group were respectively $2163 \mathrm{U} / g, 156 \mathrm{U} / \mathrm{g}, 0.57$ $\mathrm{mg} / \mathrm{g}$ and $2.79 \mathrm{mg} / \mathrm{g}$ wet weight ${ }^{(16)}$.

\section{Statistics and data presentation}

Release curves of proteins into plasma are presented as mean \pm SEM for the sake of clarity. Pearson's correlation coefficient was calculated to show relations between different parameters. A t-test for independent samples was used to assess statistically significant differences. The level of significance was set at $p<0.05$. 


\section{Figure 1}
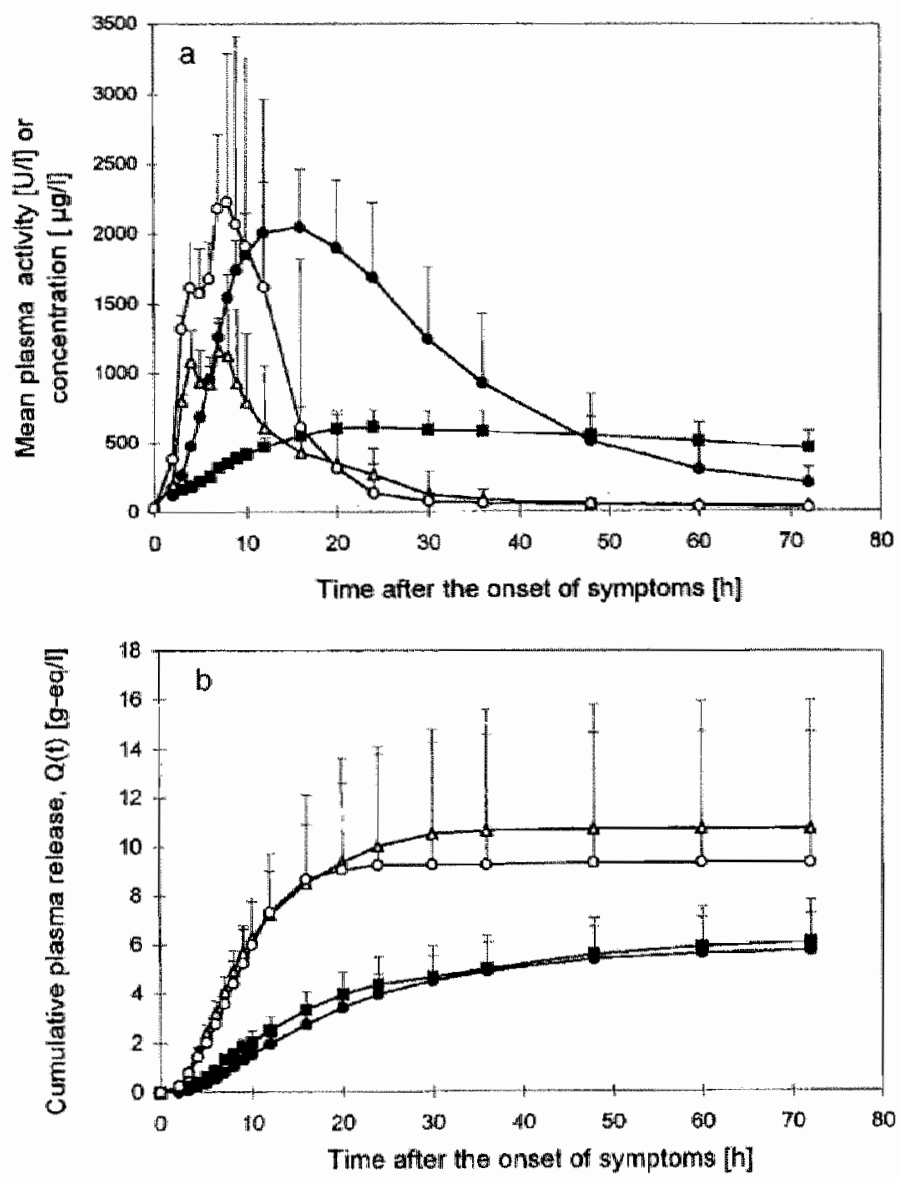

Mean plasma concentrations or activities (a) and mean cumulative plasma release expressed in gram equivalents (g-eq) of healthy myocardium per litre plasma (b) of creotine kinase (O), hydroxybutyrate dehydragenase (1). myoglobin ( $\triangle)$ and fatty acid-binding protein $(x 10,0)$ as a function of time after the onsiet of symptoms, in 20 patients. Upper standard error of the mean (SEM) is indicated. 


\section{Figure 2}

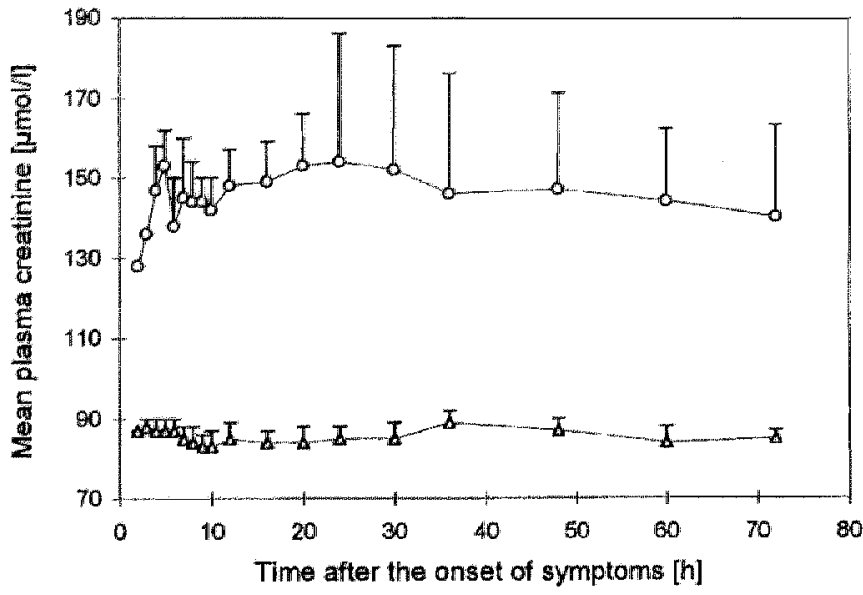

Mean plasma creatinine concentrations as a function of time for a group of patients $(n=15)$ with a mean creatinine concentrotion during the first 24 hours below the upper reference level $(\triangle)$ and for a group of patients $(n=5)$ with a mean creatinine concentration during the forst 24 hours above the upper reference level (O).

Upper standard error of the mean (SEM) is indicated.

\section{Figure 3}

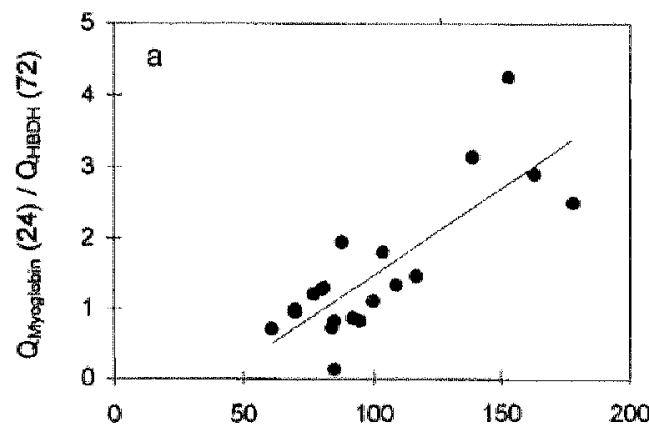

Mean creatinine over 24 hours [ $\mu$ mol/]

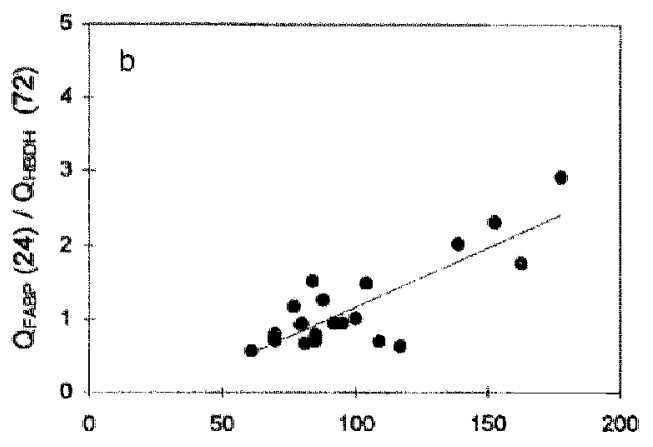

Mean creatimine over 24 hours [ $\mu \mathrm{mol} / \mathrm{]}]$
Ratio of cumulative release of myoglobin or FABP Q(24) and cumulative relecse of $\mathrm{HBDH}$ $Q(72)$ related to the mean creatimine concentrotion in the first 24 hours ofter the onset of symptoms ( $F \mathrm{gg} 3 \mathrm{a}, 3 \mathrm{~b}$ ) for 20 patients. a. $y=0.024 x-0.98, r=0.81$

b. $y=0.016 x-0.44, r=0.83$ 


\section{Figure 4}
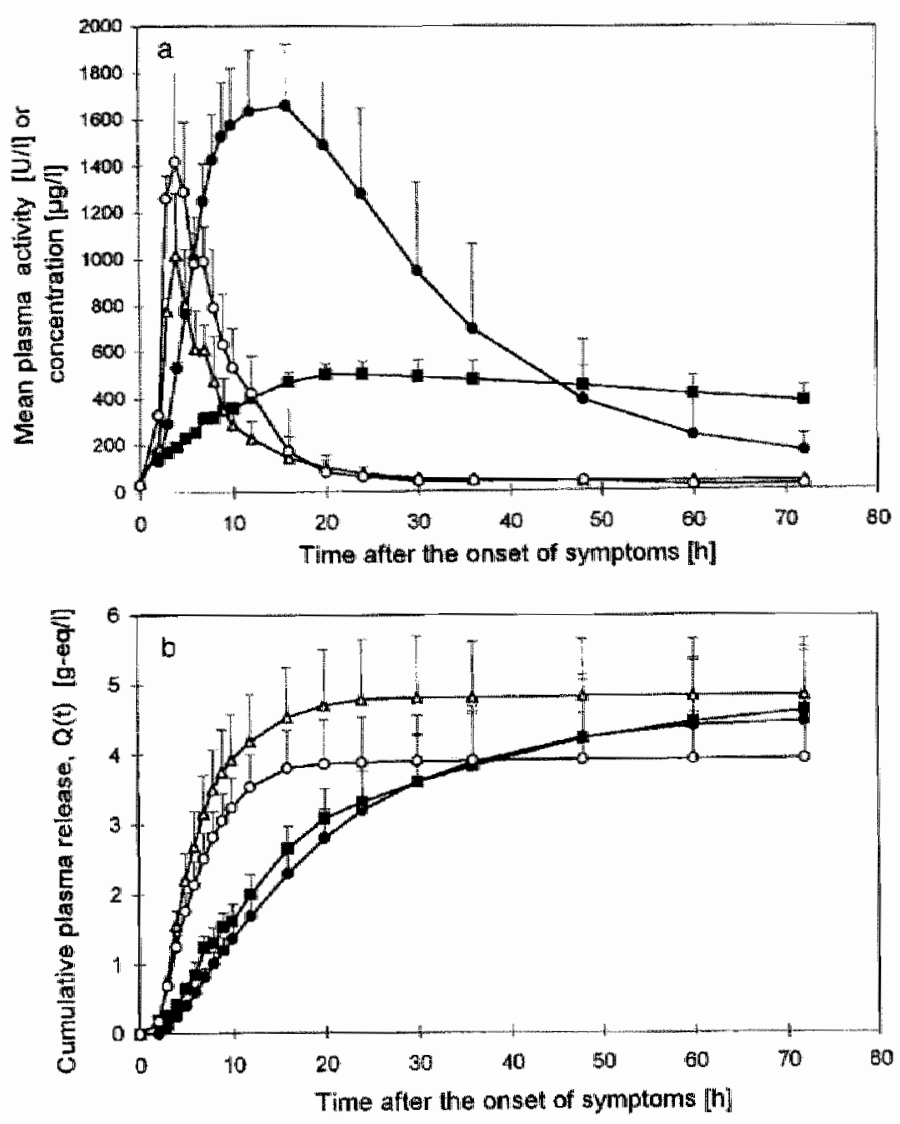

Mean plasma concentrations or activities (a) and mean cumulative release expressed in gram equivalents (g-eq) of healthy myacardium per litre plasma (b) of creatine kinase $(\cdot)$, hydroxybutyrate dehydrogenase (D), myoglobin $(\Delta)$ and fotty acid-binding protein $(x 10,0)$ as a function of time after anset of symptoms, in 15 patients with normal renal function as based on mean creatinine concentration during the first 24 hours after acute myocardial infarction. Upper standard errar of the mean (SEM) is indicated. 


\section{Figure 5}
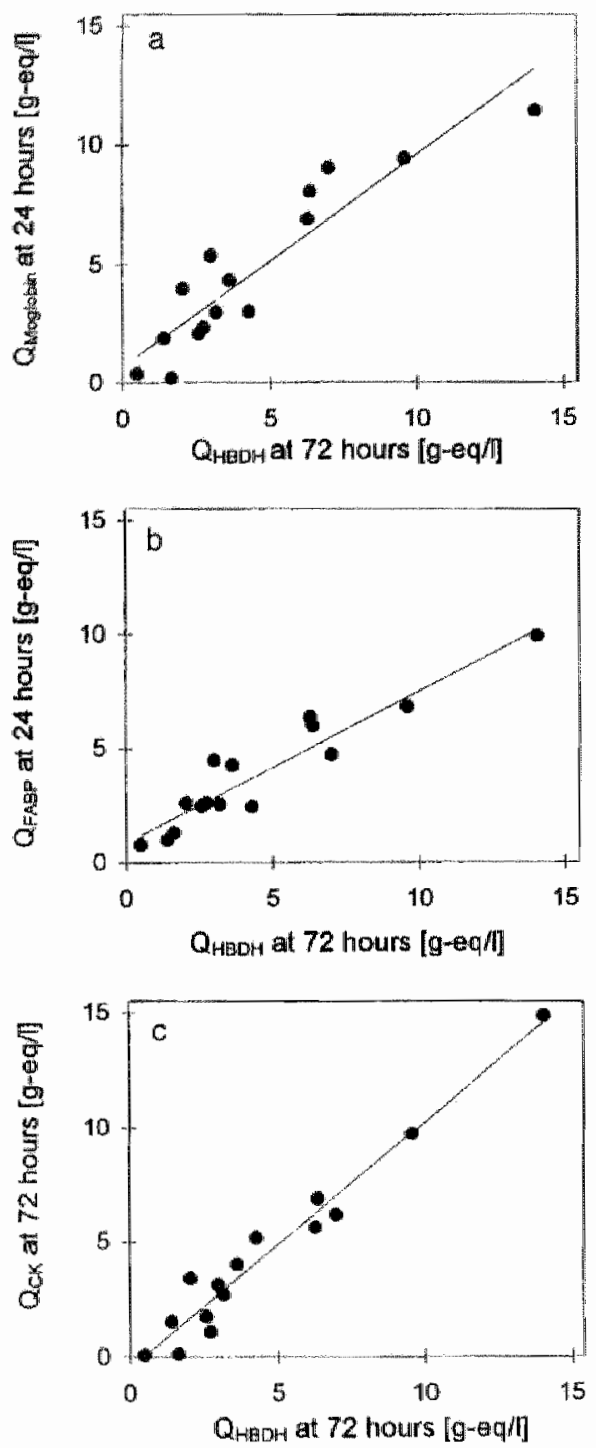

Correlation between cumulative $\mathrm{HBDH}$ release and cumulative myoglobin- (a), FABP (b) or CK- release (c) in patients with normal renal function, $n=15$.

The colculated regression lines are:
a. $y=0.88 x+0.72, r=0.92$
b. $y=0.66 x+0.84, r=0.94$
c. $y=1.07 x-0.48, r=0.98$ 


\section{Results}

\section{Mean concentration in plasma and mean cumulative release}

Mean plasma concentrations or activities of the proteins examined as a function of time for all 20 patients (Fig. Ia) showed a marked difference between the plasma kinetics of FABP and myoglobin when compared to those of $C K$ and $\mathrm{HBDH}$. For both FABP and myoglobin two peaks were seen in the mean plasma release curve. Within 24 hours the plasma concentration of both FABP and myoglobin had returned to normal, whereas it took 50-70 hours for $\mathrm{CK}$ and more than 70 hours for $\mathrm{HBDH}$.

The cumulative release patterns of the four proteins, expressed in gram equivalents of tissue per litre of plasma showed a large difference between FABP and myoglobin compared to $\mathrm{CK}$ and $\mathrm{HBDH}$ (Fig. Ib). Release of FABP and myoglobin were completed much earlier, but mean infarct size estimates obtained from myoglobin or FABP were almost twice the infarct size estimated from CK and $\mathrm{HBDH}$ plasma release curves.

As the low-molecular-mass proteins FABP and myoglobin are eliminated from plasma by renal clearance, their plasma concentrations are influenced by changes in glomerular filtration rate. Therefore, the discordance between infarct size estimated from plasma $\mathrm{CK}$ or $\mathrm{HBDH}$ release, compared to infarct size estimated from plasma myoglobin or FABP release might be caused by changes in renal function.

\section{Influence of renal function}

To examine the influence of possible changes or inter-individual differences in renal function, plasma creatinine concentrations were measured in all plasma samples. Especially during the first hours after acute myocardial infarction, haemodynamic changes introduce variations in the plasma creatinine concentration. Therefore, the mean plasma creatinine concentration was estimated from plasma creatinine concentrations measured in all samples taken during the first 24 hours after acute myocardial infarction ${ }^{(9-12)}$. On the basis of the mean creatinine concentration during the first 24 hours, the patients were divided into two groups (Table 1). Patients with a mean creatinine concentration below the upper reference limit, below $110 \mu \mathrm{mol} / \mathrm{L}$ for men and $97 \mu \mathrm{mol} / \mathrm{L}$ for women, i.e. normal renal clearance (group I) and patients with a mean creatinine concentration above the upper reference limit for creatinine, abnormal renal clearance (group 2). Figure 2 shows the mean plasma creatinine concentrations as a function of time for these two patient groups.

The ratios between infarct size estimated from cumulative myoglobin or FABP release and infarct size estimated from cumulative $H B D H$ release $\left(Q_{\text {myoglobin }} / Q_{H B D H}\right.$, 
Fig. 3a or $Q_{F A B P} / Q_{H B D H}$. Fig. 3b), was found to be related to the mean creatinine concentration in samples taken during the first 24 hours after acute myocardial infarction. Thus, for patients with mean creatinine concentrations above the upper reference level, infarct sizes as determined from myoglobin or FABP are severely overestimated. This appears to hold good especially for the larger infarcts (Table I).

\section{Cumulative release of the different cardiac markers}

Mean cumulative release was again calculated after elimination of patients with mean creatinine concentrations above the upper reference limit of creatinine (group $2, n=5$ ). Figure 4 shows the mean plasma $\mathrm{CK}$ and $\mathrm{HBDH}$ activities and the mean FABP and myoglobin concentrations as a function of time in patients with normal renal function (group 1, $n=15$ ). After elimination of patients with an increased mean creatinine concentration during the first 24 hours after the onset of symptoms, cumulatively released quantities of $\mathrm{CK}, \mathrm{HBDH}, \mathrm{FABP}$ and myoglobin amount to approximately similar estimates of infarct size. When expressed in $g$-eq of tissue per litre of plasma these figures became respectively $4.4,4.6,3.9$ and $4.8 \mathrm{~g}$-eq $/ \mathrm{L}$ and were not significantly different.

\section{Correlation between infarct size calculated with different markers}

Correlations between infarct size calculated from plasma curves using $\mathrm{HBDH}$ as a reference versus cumulative FABP, cumulative myoglobin or cumulative $C K$ are shown in Figure 5. The highest correlation was observed between $Q_{H B D H}$ and $Q_{C K}$ $(r=0.98)$. The relation between $Q_{H B D H}$ and $Q_{C K}$ was not disturbed by changes in renal function. A good correlation between $Q_{H B D H}$ and $Q_{\text {FABP }}(r=0.94)$ or $Q_{\text {myoglobin }}$ $(r=0.92)$ was found only for patients with normal renal function (group $I, n=15)$, as estimated from plasma creatinine concentrations during the first 24 hours after acute myocardial infarction. 


\section{Discussion}

\section{Quantitation of infarct size from serial plasma myoglobin or FABP concentrations}

Size estimation of myocardial infarction from serial serum myoglobin concentrations was first performed by Groth et al. ${ }^{(30)}$. In that study a reasonable correlation $(r=0.72)$ was found between the myoglobin estimates of infarct size compared to the CK-MB estimates of infarct size. Grottum et al. found a reasonable correlation $(r=0.72)$ between infarct size estimates from $C K$ and myoglobin plasma curves (31). The authors suggested myoglobin as an early marker for estimation of infarct size, because CK release starts 3-5 hours after acute myocardial infarction, whereas myoglobin release generally starts earlier and is already completed within 24 hours after acute myocardial infarction. In both studies infarct size was not expressed in gram equivalents of healthy myocardium per litre plasma ( $\mathrm{g}$-eq/L) and therefore quantitative comparison of infarct size measures obtained with CK, CK-MB and myoglobin was not possible.

It was investigated how early total $(24 \mathrm{~h})$ release of FABP could be predicted from earlier calculated values. It follows from Table I that accurate prediction with a SEE of only $8 \%$, can already be made after 10 hours $(39,40 \%$.

\section{Table I}

\begin{tabular}{llcc} 
Qt & r & SEE in $\%$ & $\boldsymbol{y}=\mathbf{a x}+\mathbf{b}$ \\
\hline Q4 & 0.59 & 72 & $Y=1.13 x+2.75$ \\
Q6 & 0.69 & 47 & $Y=0.94 x+1.95$ \\
Q8 & 0.92 & 25 & $Y=1.16 x+0.34$ \\
Q10 & 0.98 & 8 & $Y=1.10 x+0.02$ \\
Q12 & 0.99 & 5 & $Y=1.03 x+0.02$
\end{tabular}

Correlation (r) and standard errors of estimate (SEE) for the estimation of the cumulative release of FABP during 24 hours (Q24) and the curmulgtive release after thours $(Q t) . Y=$ best fit linear equations. The SEE for estimotion of Q24 from earlier Qt values is also indicated.

In the present study infarct size, estimated from plasma curves of different cardiac markers was expressed in gram equivalents of healthy cardiac tissue, using cardiac tissue contents estimated in an earlier study (16). This allowed us to quantitatively compare the infarct size measures obtained with the different cardiac 
markers. We compared infarct size estimates obtained from plasma release curves of low-molecular-mass markers like myoglobin or FABP, with infarct size estimates obtained with the established infarct size markers $\mathrm{CK}$ and $\mathrm{HBDH}$.

\section{Sources of error in infarct size estimation}

\section{Influence of renal function on estimation of infarct size}

The plasma release curves of myoglobin and FABP showed a completely similar pattern and suggest that both myoglobin and FABP are released from the heart and cleared from the bloodstream essentially in the same manner. In view of their low molecular masses, it is most likely that myoglobin $\left(M_{r} 18000\right)$ as well as FABP $\left(M_{r} 15000\right)$ are eliminated from the circuation mainly by renal clearance ${ }^{(2.32)}$. Indeed, both proteins have been found in urine from patients with acute myocardial infarction $(9,10,33)$. For myoglobin it has been demonstrated that plasma concentrations are inversely related to the glomerular filtration rate and linearly related to the serum creatinine concentration in 68 patients with renal disease (17). For FABP elevated plasma levels have also been found in case of renal insufficiency ${ }^{14,18)}$.

Acute myocardial infarction induces activation of many neurohormonal mechanisms, which all have direct influences on renal haemodynamics and excretory function. It has been demonstrated that in patients with untreated acute myocardial infarction glomerular filtration rate was initially high and decreased from day 2 to day $10(1 \mid 8 \mathrm{vs} .104 \mathrm{ml} / \mathrm{min})^{(34)}$. Comparable results were found in an earlier study where $51 \mathrm{Cr}$-EDTA clearance was measured in 10 patients immediately after acute myocardial infarction and three weeks later ${ }^{(35)}$. This implies that individual differences in renal clearance of these low-molecular-mass proteins will cause error in calculated infarct size. We measured plasma creatinine in all samples taken during the first 72 hours after acute myocardial infarction. Due to haemodynamic and plasma volume changes during the first hours after the onset of symptoms, considerable intra-individual variation in plasma creatinine concentration can occur. As cumulative FABP and myoglobin release were completed within 24 hours (see Fig. $\| \mathrm{b}$ and Fig. 4b) mean plasma creatinine was calculated from samples taken during the first 24 hours only. We found a relation between mean plasma creatinine during the first 24 hours after acute myocardial infarction and the discordance between infarct size estimated from low-molecular mass cardiac markers FABP and myoglobin, as compared to highmolecular-mass marker $\mathrm{HBDH}$.

For patients with normal mean creatinine concentrations during the first 24 hours after acute myocardial infarction there is a good correlation between infarct size estimated from plasma myoglobin or FABP release and infarct size estimated with the established infarct size marker $\mathrm{HBDH}$. For patients with increased creatinine concentrations, estimation of infarct size from plasma myoglobin or FABP curves can be severely overestimated (especially for the larger infarcts). 
Serum creatinine alone is of course not the ideal marker to express renal function, but it appeared sufficient to eliminate patients with severe disturbance of glomerular filtration. As we did not measure body weight of the individual patients, we were not able to make a more precise estimate of creatinine clearance. It is to be expected that the correlation between creatine clearance and cumulative FABP or myoglobin release will be even stronger than it is with mean serum creatinine concentration.

\section{Sampling scheme}

It has been shown that plasma myoglobin levels after acute myocardial infarction behave rather erraticly, the so-called staccato phenomenon (36). For a frequent sampling schedule, the isolated "spikes" will contribute little to the curve area and will tend to cancel. As the sampling becomes sparser; however, an accidental high or low value may introduce considerable error and this effect could be enthanced in patients treated with thrombolytic therapy, because of the accelerated release observed after such therapy. Therefore, accurate quantification of infarct size from plasma myoglobin or FABP curves is more reliable from frequently sampled plasma curves.

\section{Variation in cardiac tissue content}

The variation in myocardial myoglobin content is about $25 \%$ and is larger than the values of about $15 \%$ found for FABP and HBDH ${ }^{(16)}$. In the present study the scatter of infarct size calculated from plasma myoglobin or FABP curves, compared to infarct size estimated from plasma $\mathrm{HBDH}$ curves was comparable.

\section{Complete recovery of myoglobin and FABP}

Quantitative recovery of cytoplasmic proteins in plasma after ischaemic myocardial damage has been demonstrated in experimental studies. The total quantity of myoglobin depleted from dog heart after 2 hours of coronary occlusion ${ }^{(37)}$, and the total activities of $\mathrm{CK}$ and $\mathrm{HBDH}$ depleted from dog heart after permanent occlusion (38), equalled the calculated release of these proteins in plasma. The similarity of estimates of injury for the different cardiac markers, shown in Figure $4 \mathrm{~b}$, supports these demonstrations of complete recovery. Incomplete recovery could only be compatible with the results shown in Fig. 4b if infarcted domains existed in which all proteins remain confined and are totally prevented from reaching the circulation.

In summary, the present study shows that estimation of infarct size from serial plasma myoglobin or FABP concentrations is possible in the first 24 hours after the onset of symptoms, but only in patients with normal plasma creatinine concentrations 
during this period. For these patients a good agreement was found between infarct size estimated from the cumulative plasma $\mathrm{HBDH}$ release and infarct size estimated from the cumulative myoglobin or FABP release. 


\section{References}

1. Hearse D. Molecular enzyme release. J Mol Med 1977; 2: 185-200.

2. Kagen L. Myoglobin: methods and diagnostic uses. CRC Crit Rev Lab Sci 1978; 9: 273-302.

3. Cairns J, Missirlis E. Walker W. Usefulness of serial determinations of myoglobin and creatinine kinase in serum compared for assessment of acute myocardial infarction. Clin Chem 1983; $29: 469-73$.

4. Delanghe J, DeBuyzere M, Cluyse L. Thierens H. Clement D. Acute myocardial infartion size and myoglobin release into serum. Eur J Clin Chem Clin Biochem 1992; 30: 823-30.

5. Mair J, Artner-Dworzak E, Lechleiter P, Morass B, Smidt J, Wagner I, et al. Early diagnosis of acute myocardial infarction by a newly developed rapid immunoturbidimetric assay for myoglobin. Br Heart J 1992; 68: 462-8.

6. Ellis $K$, Little $T$, Masud Z, Liberman H, Morris D. Klocke F. Early non-invasive detection of successful reperfusion in patients with acute myocardial infarction.l. Circulation 1988; 78 : 1352-7.

7. Katus HA, Diederich K, Scheffold T, Uellner M, Schwarz $F$, Kubler W. Non-invasive assessment of infarct reperfusion: the predictive power of time to peak value of myoglobin, CKMB and CK in serum. Eur Heart J 1988; 619-24.

8. Yamashita $T$, Abe $S$, Arima $S$, Nomoto K, Miyata M, Maruyama I, et al. Myocardial infarct size can be estimated from serial plasma myoglobin measurements within 4 hours of reperfusion. Circulation 1993; 87: 1840-9.

9. Tanaka $T$, Hirota $Y$, Sohmiya $K$, Nishimura $S$, Kawamura $K$. Serum and urinary heart fatty acid binding protein in acute myocardial infarction. Clin Biochem 1991: 24: 195-201.

10. Kleine A, Glatz J, Van Nieuwenhoven F, Van der Vusse G. Release of fatty-acid binding protein into plasma after acute myocardial infarction in man. Mol Cell Biochem 1992; 116: 155-62.

11. Glatz J, Kleine A, Van Nieuwenhoven F, Hermens WT, Van Dieijen-Visser M, Van der Vusse $G$. Fatty-acid-binding protein as a plasma marker for the estimation of myocardial infarct size in humans. Br Heart J 1994; 71 : 135-40.

12. Glatz ], Van der Vusse G. Cellular fatty acid binding proteins: Current concepts and future directions. Mol Cell Biochem 1990; 98: 237-51.

13. Glatz ], Van der Vusse G. Cellular fatty acid-binding proteins: their function and physiological significance. Progress in Lipid Research 1996. In press.

14. Van Nieuwenhoven F, Kleine A, Wodzig K, Hermens $W$, Kragten $H$, Maessen $J_{\text {, et al }}$ Discrimination between myocardial and skeletal muscle injury by assessment of the plasma ratio of myoglobin over fatty acid-binding protein. Circulation 1995; $92: 2848.54$.

15. Yoshimoto K. Tanaka T, Somiya K, Tsuji R, Okamoto F, Kawamura K, et al. Human hearttype cytoplasmic fatty acid-binding protein as an indicator of acute myocardial infarction. Heart Vessels 1995; 10: 304-9.

16. Kragten J, Van Nieuwenhoven F, Van Dieijen-Visser M. Theunissen P. Hermens W, Glatz J. Distribution of myoglobin and fatcy acid binding protein in human cardiac autopsies. Clin Chem 1996; 42: 337-8.

17. Hallgren $R$, Karlsson F, Roxin L, Venge P. Myoglobin turnover, influence of renal and extrarenal faccors. I Lab Clin Med 1978; $91: 246-54$.

18. Gorski J, Hermens W, Borawski J. Mysliwiec M, Glatz J. Fatty acid-binding protein concentration of patients with chronic renal failure is elevated. Clin Chem 1996. In press.

19. Delanghe J, Chapelle J, Magdeleine E, DeBuyzere M. Quantitative turbidimetric assay for determining myoglobin evaluated. Ann Clin Biochem 1991; 28: 474-9. 
20. Wodzig K, Pelsers M, Van der Vusse $G$. Roos W. Glatz J. One-step enzyme-linked immunosorbent assay (ELISA) for plasma fatty acid-binding protein. Ann Clin Biochem 1996. In press.

21. Visser $M$, Krill $M$. Willems $G$, Hermens $W$. Selection of a suitable model for the plasma clearance and distribution of cardiac enzymes in the dog. Cardiovasc Res 1981; 15: 35-42.

22. Van Kreel B, Van der Veen F, Willems $G$. Hermens W. Circulatory modells in assessment of cardiac enzyme release in dogs. Am J physiol 1993; (Heart Cire Vol 33): H747-54.

23. Willems $G$, Visser M, Krill M. Hermens W. Quantitative anallysis of plasma enzyme levels based on simultaneous determination of different enzymes. Cardiovasc Res 1982; 16: 120-31.

24. Koskelo P, Kekki M, Wager $O$. Kinetic behavior of 131 l-labeled myoglobin in human beings. Clin Chim Acta 1967; 17: 339-47.

25. Sylven $C$. The kinetics of myoglobin in old volunteers and in patients with acute myocardial infarction. Scand I Clin Lab Invest 1979; 38: 561-65.

26. Groth T, Sylven C. Myoglobin kinetics in patients suffering from acute myocardial infarction in its early phase- as studied by the single injection method. Scand J Clin Lab Invest 1981; 44: $65-78$.

27. Geigy. Wissenschaftliche Tabellen, Korperflussigkeiten 8. Basel, 1977.

28. Renkin E. Multiple pathways of capillary permeability. Circ Res 1977; 41: 735-43.

29. Renkin E, Curry F. Transport of water and solutes across capillary endothelium, 1979.

30. Groth $T$, Hakman $M$, Sylven $C$. Size estimation of acute myocardial infarction from serial serum myoglobin observations with due consideration of individual differences in basic kinetics. Scan J Clin Lab Invest. 1984; 44: 65-78.

31. Grottum P, Sederholm M, Kjekshus J. Quantitative and temporal relation between the release of myoglobin and creatine kinase and the evolution of vectorcardiographic changes during acute myocardial infarction in man. Cardiovasc Res 1987; 21: 652-9.

32. Rabkin R, Dahl D. Renal uptake and disposal of proteins and peptides. New York: Plenum Press, 1993.

33. Tsuji R, Tanaka T, Sohmiya K, Nishimura S, Kawamura K. Human heart-type cytoplasmic fatty acid-binding protein as an indicator of acute myocardial infarction. Int J Cardiol 1993; 41: 209-17.

34. Abildgaard U, Andersen J, Daugaard G, Aldershville J, Nielsen S, Christensen N, et al. Renal function in patients with untreated acute myocardial infarction.. Scand J Clin Lab Invest 1992; 52: $689-5$.

35. Efendigil M. Harley A. Deegan T. McKendrick C. Changes in glomerular filtration rate following myocardial infarction. Cardiovascular Research 1975; 9: 741-4.

36. Kagen L. Scheidt S, Butt A. Serum myoglobin in myocardial infarction: The "staccato phenomenon/E. Am J Med 1977; 62; 86-92.

37. Ellis A, Saran B. Kinetics of myoglobin release and prediction of myocardial depletion after coronary artery reperfusion. Circulation 1989; 80: 676-83.

38. Hermens $W$, Van der Veen $F$, Willems $G$, Mullers-Bouman $M$, Schrijvers-van Schendel $A$, Reneman $R$. Complete recovery in plasma of enzymes lost from the heart after permanent coronary occlusion in the dog. Circulation 1990; 81: 649-59.

39. Wodzig KWH, Pelsers MMAL, Van Dieijen-Visser MP, Kragten JA, Hermens WTh, Van der Vusse G], Glatz JFC. Vetzuur bindend eiwit als niet-enzymatische merker voor schatting van de grootte van het acuut myocardinfarct bij de mens. Ned Tijdschr voor Geneesk. 1996; 140: $2315 \times 16$

40. Wodzig KWH, Pelsers MMAL, Van Dieijen-Visser MP, Kragten JA, Hermens WTh, Van der Vusse G], Glatz JFC. Fatty acid-binding protein as a predictive non-enzymatic marker of acute myocardial infarct size in humans. Ned Tijdschr Klin Chem 1996; 21 : no. 2: 98-9 
Chapter 6

Summary and conclusions 
The aim of the investigations described in this thesis is to contribute to improvement of diagnosis and treatment of patients with coronary syndromes. Special attention has been paid to the application of increasing knowledge on marker proteins in relation to cardiac tissue necrosis. For many years these cardiac markers were enzymes involved in cellular metabolism, but in the last decade other markers, notably structural proteins, have been suggested as better alternatives. Although markers with widely differing properties have been introduced, at this moment no perfect cardiac marker exists. However, the combination of several markers may provide information to answer the clinician's questions depending on the circumstances of the individual patient and the course of his/her disease.

In the emergency room, the clinician meets both patients suffering from acute myocardial infarction and patients with unstable angina pectoris. When acute myocardial infarction is present with a typical medical history and clear signs of persisting ischaemia and/or necrosis in the electrocardiogram, there is no need to establish the diagnosis with a cardiac marker. However, when the clinical history is suspect or the electrocardiographic changes are not specific, i.e. in approximately 30 $\%$ of the cases, the use of an early myocardial marker can be helpful in diagnosis or exclusion of acute myocardial infarction. In all patients, estimation of infarct size may be useful for better risk stratification and appropriate post-infarction treatment.

Unless there is a contra-indication to do so, patients with acute myocardial infarction will be treated preferably with thrombolysis. After thrombolysis, measurement of serial changes of plasma cardiac marker concentrations can be helpful for non-invasive assessment of successful coronary reperfusion. Until now no prospective trials have been published, investigating whether the decision on vessel patency can be based on release patterns of cardiac markers in the serum of the patient and whether this should influence treatment strategy.

Better knowledge of the content and distribution in normal cardiac tissue and of the plasma release characteristics of these new cardiac markers after myocardial tissue damage will give better insight in the potential use of these alternative markers in different clinical situations. We inwestigated these aspects for the new cardiac marker proteins troponin T, myoglobin and fatty acid-binding protein and compared their characteristics with those of the traditionally used cardiac enzymes creatine kinase, lactate dehydrogenase and hydroxybutyrate dehydrogenase.

In Chapter I, a survey on diagnostic aspects and on the potential use of different cardiac marker proteins has been given. Traditionally rises in creatine kinase, its myocardial isoform creatine kinase MB. lactate dehydrogenase or aspartate aminotransferase activity are widely used markers of cardiac cell damage. However, daily clinical practice teaches that these markers have several limitations. In cases of skeletal muscle injury, there is a lack of specificity. In the early hours after acute myocardial infarction sensitivity is low due to delayed appearance of these markers in plasma. In addition the sensitivity of enzyme measurements is not sufficient to detect minor myocardial cell damage, due to the analytical imprecision of activity measurements. 
New assays and markers have been introduced which to some extent overcome these shortcomings. Among these must be mentioned creatine kinase$M B_{\text {mass }}{ }^{*}$ troponin $T$ and troponin I and also myoglobin and fatty acid-binding protein. Especially the troponins have good cardiac specificity. However, these structurally bound proteins have to be dissociated from the contractile myofibrillar structures, before they can be released into the circulation and are therefore released more slowly than free cytosolic proteins. However, this relatively slow plasma release of the troponins allows even minor cardiac cell damage to be diagnosed, even several days after onset of complaints.

Myoglobin and fatty acid-binding protein are small cytoplasmic proteins showing earlier washout from injured tissue and earlier rise of plasma concentrations after acute myocardial infarction compared to other markers, making them especially suitable for early diagnosis. However, these low molecular mass proteins are not cardiac specific and are subject to renal clearance. Therefore their plasma concentrations can be influenced by skeletal muscle damage, for instance due to cardioversion or intramuscular injections, and by changes in renal function. Their short half-life in plasma makes them especially suitable to detect reinfarctions or extension of acute myocardial infarction.

\section{Biochemical markers in normal cardiac tissue}

Although measurements of myocardial marker proteins in plasma are mainly used for diagnostic purposes, interest is growing in their application for estimation of infarct size and for the detection of even minimal myocardial necrosis. For a quantitative translation of plasma protein concentrations in lost muscle mass, it must be assumed that variation in protein content of cardiomyocytes from different: individuals is small. Knowledge of the quantitative distribution of these markers in heart tissue is therefore essential. Variations in cardiac enzyme content have been extensively studied, but for cardiac proteins such as myoglobin, fatty acid-binding protein and troponin $T$ only few data were avalllable.

In Chapter 2, tissue samples taken from 17 hearts obtained at autopsy within 24 hours after death by non-cardiac causes were studied. Mean tissue activities or protein content, per gram wet weight of tissue, were for HBDH $156+25 \mathrm{U} / \mathrm{g}$, for $\mathrm{LDH} 385 \pm 59 \mathrm{U} / \mathrm{g}$ lactate and for $\mathrm{TnT} 234 \pm 65 \mu \mathrm{g} / \mathrm{g}$. Overall variation in $\mathrm{TnT}$ content $(27 \%)$ was higher than for $\mathrm{LDH}$ or $\mathrm{HBDH}(15 \%)$, but this could partly be caused by the fact that troponin $T$ has to be released from the myofibrils before determination, which might increase analytical variation. It has been reported that HBDH and LDH are not susceptible to autolysis. The same was true for $T n T$, as its cardiac concentration was not influenced by autopsy delay. 
In a similar study with 14 hearts obtained from autopsies, we examined both intra- (transmural) and inter-individual variations in myoglobin and FABP content in epi-, mid- and endocardial samples (Chapter 4). Results were compared with variation in cardiac tissue content of the established cytoplasmic infarct size markers $\mathrm{HBDH}$ and $\mathrm{LDH}$. Mean cardiac tissue contents of $161 \pm 24 \mathrm{U} / \mathrm{g}$ for $\mathrm{HBDH}, 397 \pm 57 \mathrm{U} / \mathrm{g}$ for $L D H, 2.79 \pm 0.71 \mathrm{mg} / \mathrm{g}$ for myoglobin and $0.57 \pm 0.09 \mathrm{mg} / \mathrm{g}$ for FABP were found.

Variation in cardiac FABP content was comparable with variation in cardiac $\mathrm{HBDH}$ and $\mathrm{LDH}$ content, that is, about $15 \%$. Overall variation in cardiac myoglobin content was somewhat higher. In our study "there was no influence of age, autopsy delay or localisation of the heart. This is important when quantitative conclusions are to be made on the release patterns of these markers. In chopter 4 a significant negative correlation was found between heart mass and cardiac tissue content of all four mentioned markers, due to cardiac hypertrophy and dilution of the muscle with connective tissue.

\section{Quantification of marker protein release}

The extent of cardiac tissue damage is related to the patient's prognosis quoad vitam and therefore important. Enzymatic assessment of the extent of ischaemic myocardial injury has become normal clinical practice and has been successfully applied in the evaluation of thrombolytic therapy. It was demonstrated that the favourable effects of such therapy, namely preservation of myocardial function and reduced mortality, can be explained by limitation of infarct size and this has stimulated the interest in the quantitative interpretation of enzymatic data and in the methodological aspects of such analysis. Apart from the present study, no data have been published on the quantification of $\mathrm{TnT}$ release and only few on the quantification of myoglobin and FABP release into plasma.

In Chapter 2 the completeness of release was compared for TnT, HBDH $(\mathrm{LDH})$ and $\mathrm{CK}$ in 22 patients with acute myocardial infarction, who were treated with thrombolytic therapy. Enzyme activities or protein concentrations were assayed serially in plasma samples obtained very frequently and for at least 168 hours after the onset of first symptoms. Cumulative release in plasma was calculated by using a twocompartment model for circulating proteins. Cumulative plasma release was expressed in gram equivalents ( $g$-eq) of myocardium per litre plasma (infarct size), using the mean cardiac protein contents found in Chapter $I$.

For $\mathrm{CK}, \mathrm{HBDH}$ and $\mathrm{LDH}$, total release did not further increase after 72 hours and amounted to about $6 \mathrm{~g}$-eq $/ \mathrm{L}$. Differences between mean infarct sizes for these three enzymes were not significant. For $T n T$, however, total release during the first 72 hours only amounted to a mean infarct size of $0.30 \mathrm{~g}$-eq/L $(5 \%)$, and thereafter increased to $0.51 \mathrm{~g}$-eq $/ \mathrm{L}(8.5 \%)$ after 168 hours. This can be explained by assuming that the cytosolic fraction of $T n T$ in cardiac tissue amounts to only about $5 \%$ of total $\mathrm{TnT}$ content and is released earlier compared to the TnT fraction bound to the 
myofibrillar structures. The different release rates for the free cytosolic versus the bound TnT fraction may give rise to a biphasic plasma release curve, especially in patients showing early reperfusion after acute myocardial infarction. In spite of this incomplete recovery, cumulative troponin $T$ release after 72 and 168 hours and troponin $T$ peak values correlated well with infarct size as estimated from cumulative CK, HBDH and LDH release over 72 hours.

\section{Influence of thrombolytic treatment on protein release patterns}

Coronary reperfusion could enhance the washout of marker proteins from the necrotic tissue and thereby influence the recovery in plasma of unstable marker proteins. In addition, such reperfusion could influence the liberation of structurally bound TnT. In Chapter 3, these possibilities were investigated in two groups of patients. Patients in the first group were treated with thrombolytic therapy, while for several reasons such treatment was not given to the parients in the second group. Delayed time to peak values were found for the cardiac enzymes and for troponin $T$ in patients not treated with thrombolytic therapy, compared to patients treated with thrombolytic therapy. Plasma TnT curves in patients treated with thrombolytic therapy who showed signs of successful reperfusion, as judged from clinical symptoms and angiography within 24 hours, had a more pronounced biphasic character than curves from patients without thrombolytic treatment or showing no clinical symptoms of reperfusion. However, reperfusion did not influence the recovery in plasma of TnT, compared to CK or $\mathrm{HBDH}$.

\section{Early markers and the influence of renal function}

Myoglobin and FABP are low molecular mass cytoplasmic proteins, which are considered usefull biochemical markers for early detection or exclusion of acute myocardial infarction. Both proteins are not only rapidly released but, due to their low molecular mass, are also subject to rapid renal clearance leading to short turnover times. Plasma concentrations are dependent on adequate renal function and elevated concentrations may be measured in cases of renal dysfunction, leading to overestimation of cumulative release and infarct size. The early washout of these low molecular mass proteins makes them also especially suitable for detection of reperfusion from the initial slopes of the plasma curves after start of thrombolytic therapy.

In Chapter 5 we studied the influence of renal dysfunction on infarct size as calculated from plasma curves of myoglobin and FABP. Overestimation of infarct size as calculated from these marker proteins was defined as the idegree of overestimation of infarct size values found for the established markers CK and $\mathrm{HBDH}$, which are not 
eliminated by renal clearance. A correlation was found between the average plasma creatinine concentration during the first 24 hours after acute myocardial infarction, used as a measure for renal dysfunction, and the degree of overestimation of infarct size as calculated for myoglobin and FABP. In patients with mean plasma creatinine concentrations within the reference interval for creatinine we found a good agreement between infarct size estimated from all four markers. However, for plasma creatinine concentrations exceeding the upper reference limit of $120 \mu \mathrm{mol} / \mathrm{L}$, infarct size as calculated from cumulative myoglobin and FABP release curves was markedly overestimated. It is recommended that when low molecular marker proteins for calculation of infarct size are used, renal function must be carefully checked, e.g. twice within the first 24 hours.

\section{Conclusions}

- Variation in TnT, myoglobin, FABP, LDH and HBDH content in normal cardiac tissue is of the order of $15 \%$ and these proteins are equally divided transmurally. This implicates that the site of infarction has minor influence on the calculation of infarct size.

- Cumulative troponin $T$ release is incomplete, and only a fraction of cumulative cardiac enzyme release (5\% after 72 hours and $8.5 \%$ after 168 hours). Nevertheless, a good correlation between troponin $T$ release and cardiac cytosolic enzyme release was found in patients with acute myocardial infarction. As troponin $T$ is still released into circulation at least 170 hours after the onset of symptoms, it is evidently a good marker for detection of cell necrosis if the patient presents in the emergency department late after the onset of chest pain. This is especially interesting because other indicators such as electrocardiogram and medical history might not be conclusive any more, especially when the preceding ECG already showed $\mathrm{Q}$-waves as a sign of earlier infarction.

- The completeness of cumulative troponin $T$ release is not influenced by thrombolytic therapy or patency of the infarct-related vessel. Reperfusion, with reoxygenation and possible formation of reactive free radicals (reperfusion injury apparently does not influence the liberation of TnT from the myofibrills.

- With respect to the release of cytoplasmic proteins, cumulative release of the low molecular mass proteins myoglobin and FABP is completed within 24 hours after the onset of symptoms, whereas the release of the high molecular mass cardiac enzymes CK and HBDH is not completed before 72 hours.

From the data reported in Chapter 5 it can be concluded that already after 10 hours a reliable estimate of infarct size ( $\mathrm{SEE}=8 \%$ ) can be made on the basis of FABP. 
- Since calculated cumulative release of low molecular mass markers may be influenced by renal function, infarct size as calculated from such markers should only be used if plasma creatinine values remain below $120 \mu \mathrm{mol} / \mathrm{L}$ during the first 24 hours after infarction, or with corrections performed for the remaining cases.

- In the present study, myocardial protein content was determined in healthy hearts, while hearts as found in patients who died after AMI contained lower amounts of these proteins. However, it follows from chapter 5 that the ratios of released cytosolic proteins conform to the protein content ratios of healthy hearts. This indicates that the pathological changes as found in the hearts of patients with AMI can be described as dilution of normal muscle cells with connective tissue (collagen, fat, edema).

- Enzyme activity is generally sensitive to perturbation of the tertiary structure of the molecule, whereas the antigenic epitopes in myoglobin and FABP used in their immunoassays are localised and relatively stable structures. Nevertheless, similar estimates of infarct size were found from enzymatic and non-enzymatic proteins, indicating that protein denaturation before cellular release or during transport from heart to plasma must have been limited. The same conclusion follows from the equal values of infarct size obtained from a labile enzyme such as $\mathrm{CK}$ and a relatively stable enzyme such as $\mathrm{HBDH}$. 
Hoofdstuk 7

Samenvatting en conclusies 
Het doel van de onderzoeken, die in deze thesis zijn beschreven, is een bijdrage te leveren aan het verbeteren van de diagnostiek en de behandeling van patiënten met een acuut myocardinfarct. Er is speciale aandacht besteed aan het toepassen van de toegenomen kennis van biochemische veranderingen in relatie tot hartspiernecrose. De mate van necrose kan worden gecorreleerd aan de uitstorting van de zogenaamde cardiale merkers in het plasma bij patiënten met een acuut myocardinfarct. Bepaalde enzymen werden gedurende vele jaren als merkers gebruikt, maar in het laatste decennium is gesuggereerd, dat andere eiwitmerkers en met name zij die specifiek aanwezig zijn in hartweefsel en uit deze weefsels wegsijpelen wanneer necrose optreedt, een beter alternatief zouden zijn. De eisen, waaraan een cardiale merker moet beantwoorden, kunnen wisselen, afhankelijk van de omstandigheden. De perfecte cardiale merker zou op diverse vragen tegelijk antwoord moeten geven, zowel met betrekking tot de ziektetoestand van de patiënt als tot de meest geschikte behandeling en ook tot de uiteindelijke prognose. Hoewel er verschillende merkers zijn geïntroduceerd, bestaat er op dit moment geen perfecte cardiale merker. Door evenwel verschillende merkers te combineren, kan een antwoord worden gegeven op de vraagstelling van de clinicus, afhankelijk van de klinische toestand van de individuele patiënt en het verloop van diens ziekte.

Op de EHBO wordt de clinicus geconfronteerd met patiënten die reeds een acuut myocardinfarct doormaken en met patiënten met een instabiele angina pectoris. Wanneer reeds een acuut myocardinfarct aanwezig is met typische STveranderingen op het elektrocardiogram en een suspecte anamnese, bestaat er geen behoefte, deze diagnose ook nog d.m.v. een cardiale merker bevestigd te krijgen. In dit soort gevallen kan de diagnose 'acuut myocardinfarct' zonder laboratoriumbepalingen worden gesteld. Wanneer elektrocardiogram-veranderingen echter niet specifiek zijn voor een acuut infarct, terwijl de anamnese verdacht is - en dit komt in ongeveer $30 \%$ van de gevallen voor - kan het gebruik van een hoog specifieke en vroege merker van nut zijn om deze diagnose te stellen of uit te sluiten. Tenzij er een contra-indlicatie bestaat zullen patiënten met een acuut myocardinfarct bij voorkeur met trombolyse worden behandeld. Nadat trombolyse is gegeven kan een stijging en daling van de plasmaconcentratie van cardiale merkers van betekenis zijn om zo snel mogelijk reperfusie aan te tonen. Tot nu toe zijn geen prospectieve onderzoeken gepubliceerd, waarin is nagegaan of het bestaan van reperfusie aan de hand van een specifiek patroon van toename en afname van cardiale merkers in het serum van de patiënt kan worden vastgesteld, zodat de behandelstrategie daaraan kan worden aangepast.

Een overzicht over diagnostische aspecten alsmede over de voorkeur voor het gebruik van verschillende cardiale eiwitmerkers wordt in hoofdstuk | behandeld. Gewoonlijk worden stijgingen van de activiteit van creatine kinase, het hartspierspecifieke iso-enzyme en het melkzuur dehydrogenase of aspartaat aminotransferase op grote schaal gebruikt als merkers van cardiale weefselschade. De dagelijkse klinische praktijk leert ons echter, dat deze merkers een aantal beperkingen hebben. In geval van skeletspierschade bestaat er een gebrek aan specificiteit. In de eerste uren na een 
acuut myocardinfarct is de sensitiviteit laag als gevolg van een vertraagd verschijnen van deze merkers in het bloed. Bovendien is de gevoeligheid van enzymbepalingen miet voldoende om een beperkte hartweefselschade vast te stellen als gevolg vain een ongevoelige analytische meetmethode van deze activiteit. De nieuwe serie merkers die geïntroduceerd is, lost deze tekortkomingen voor een deel op. Onder deze merkers moet de creatine kinase- $\mathrm{MB}_{\text {massa }}$ worden genoemd alsmede ook de

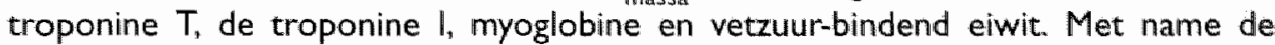
troponines hebben een goede cardiale specificiteit. Echter de troponines zijn gebonden aan de contractiele elementen en moeten hiervan dissociëren voordat ze in de circulatie kunnen komen. Zij worden derhalve langzamer in de circulatie uitgescheiden in vergelijking tot de vrije cytosolische enzymen en eiwitten zoals creatine kinase, creatine kinase-MB massa, melkzuur dehydrogenase, hydroxyboterzuur dehydrogenase en in het bijzonder ten opzichte van het myoglobine en het vetzuur-bindend eiwit. Deze relatief langzame uitscheiding van het troponine in het plasma stelt ons in staat, geringe hartweefselschade te diagnostiseren, zelfs meerdere dagen nadat deze schade is opgetreden. Myoglobine en vetzuur-bindend eiwit zijn kleine cytoplasmatische eiwitten, die een smelle 'wash out' hebben vanuit beschadigd weefsel en een vroege plasmaconcentratiestijging geven na een acuut myocardinfarct in vergelijking tot alle andere merkers. Hierdoor zijn deze met name geschikt voor vroege diagnostiek. Deze eiwitten met een lage moleculaire massa zijn echter niet cardiospecifiek en zij worden via de nieren uitgescheiden. Hun plasmaconcentratie kan derhalve worden beinvloed door veranderingen in de nierfunctie. De korte halfwaardetijd van deze massa-eiwitten in het plasma maakt hen bijzonder geschikt om een reinfarct vast te stellen. Een betere kennis van de aanwezigheid en verdeling van deze nieuwe merkers in gezond hartspierweefsel en de karakteristieke uitscheiding in het plasma na myocardschade zal ons een beter inzicht geven in de mogelijkheden van deze alternatieve merkers in verschillende klinische situaties. Wij onderzochten deze aspecten voor de nieuwe eiwitmerkers van het hart troponine $T$, myoglobine en vetzuur-bindend eiwit en hebben hun karakteristieken vergeleken met die van de traditioneel gebruikte cardiale enzymen zoals creatine kinase melkzuur dehydrogenase en hydroxyboterzuur dehydrogenase.

\section{Biochemische merkers in normaal hartweefsel}

Hoewel kwantitatieve bepalingen van intracellulaire enzymen of eiwitten, die na het ontstaan van hartweefselschade in het plasma verschijnen, voornamelijk worden gebruikt voor diagnostische doeleinden, is er een groeiende interesse in hun toepassing voor het bepalen van de infarctgrootte. Voor een kwantitatieve bepaling van hartweefselschade door plasma-eiwit- of plasma-enzymconcentraties is ervan uitgegaan, dat er individueel slechts kleine verschillen zijn in de aanwezigheid van deze enzymen in thet hart. Het is van groot belang kennis te hebben van de kwantitatieve verdeling van deze merkers in normaal hartweefsel. Ook is het belangrijk kennis te 
hebben van de spreiding van deze merkers over de verschillende gebieden van het hart, zoals onderwand en achterwand of voorwand en zijwand. Ook de endocardiale en myocardiale locatie is van belang. Een exacte bepaling van de infarctgrootte met gebruik van plasmaconcentraties van een cardiale merker is alleen mogelijk, wanneer de variatie in de aanwezigheid van deze merker in hartweefsel gering is. Om het mogelijk te maken de infarctgrootte " bepaald uit plasmacurves van verschillende cardiale merkers, te vergelijken, moet de infarctgrootte worden uitgedrukt in gramequivalenten ( $\mathrm{g}$-eq) gezond hartweefsel per liter plasma ( $\mathrm{g}$-eq/l). Om dit te kunnen doen moet de totale hoeveelheid vrijgekomen cardiale merker per liter plasma worden gedeeld door de hoeveelheid van deze merker per gram gezond hartweefsel. Variaties in hoeveelheden eerder bekende cardiale enzymen zijn uitgebreid bestudeerd maar over cardiale eiwitten, zoals myoglobine, vetzuur-bindend eiwit en troponine $T$, zijn slechts weinig gegevens bekend.

Om de weefselconcentraties van de enzymen hydroxyboterzuur dehydrogenase, melkzuur dehydrogenase en het eiwit troponine $T$ te kunnen bepalen zijn van 17 harten, die verkregen werden door autopsie van patiënten die aan een niet cardiale dood overleden, binnen 24 uur na het overlijden stukjes weefsel weggenomen. (Dit wordt beschreven in hoofdstuk 2). Per gram ongedroogd gewicht hartweefsel werd $156 \pm 25 \mathrm{U} / g$ hydroxyboterzuur dehydrogenase, $385 \pm 59 \mathrm{U} / \mathrm{g}$ melkzuur dehydrogenase en $234 \pm 65 \mathrm{mg} / \mathrm{g}$ troponine $T$ gevonden. De variatie van troponine $T(27 \%)$ is hoger in vergelijking met de gemiddelde variaties van melkzuur dehydrogenase en hydroxyboterzuur dehydrogenase (15\%), maar dit wordt deels verklaard door het feit dat troponine $T$ van de myofibrillen moest worden losgemaakt, voordat het bepaald kon worden en dit kan een oorzaak zijn voor een toename in analytische variatie. Elders was reeds aangetoond, dat bij hydroxyboterzuur dehydrogenase en melkzuur dehydrogenase geen autolyse optreedt en dat de enzymhoeveelheid in monsters verkregen bij autopsie vergeleken kan worden met de enzymhoeveelheid in vers hartweefsel. Hetzelfde geldt voor troponine $T$, daar de cardiale concentratie niet werd beinvloed door de tijdsduur, verstreken tussen het moment van overlijden en het moment waarop autopsie plaatswond (hoofdstuk 2).

Daar het bekend is dat de hoeveelheid creatine kinase in bij autopsie verkregen monsters afneemt, is gebruik gemaakt van de in de literatuur bekende waarde van $2163 \mathrm{U} / \mathrm{g}$ in vers weefsel. In een gelijksoortige studie met 14 harten, verkregen uit autopsie, werd onderzoek gedaan zowel naar intra- individuele als naar interindividuele variaties in concentraties van myoglobine en vetzuur-bindend eiwit in zowel epi-, mid-als endocardiale monsters (hoofdstuk 4).

De resultaten van de onderzoeken naar deze cytoplasmatische eiwitten werden vergeleken met variaties in anwwezigheid van de traditionele cytoplasmatische merkers voor infarctgrootte in hartweefsel zoals hydroxyboterzuur dehydrogenase of melkzuur dehydrogenase, waarvan bekend is dat ze opvallend stabiel zijn bij autopsie. De gemiddelde hoeveelheid hydroxyboterzuur dehydrogenase in hartweefsel is $161 \pm 24 \mathrm{U} / \mathrm{g}$, van melkzuur dehydrogenase is dit $397 \pm 57 \mathrm{U} / \mathrm{g}$, van myoglobine $2,79 \pm 0.71 \mathrm{mg} / \mathrm{g}$ en van vetzuur-bindend eiwic $0.57 \pm 0.09 \mathrm{mg} / \mathrm{g}$. 
Wij hebben vastgesteld, dat de variatie in concentratie van vetzuur-bindend eiwit in hartweefsel vergelijkbaar is met variaties in aanwezigheid van hydroxyboterzuur dehydrogenase en melkzuur dehydrogenase in dat weefsel en dat dit slechts $15 \%$ is. De gemiddelde variatie in het hartspierweefsel van cardiale myoglobine is ongeveer $10 \%$ hoger. In onze studie was er geen invloed van leeftijd, tijdsduur tussen moment van overlijden en moment van autopsie of lokalisatie van het weefsel.

Op deze gronden kan worden geconcludeerd, dat de concentratie van deze merkers in thartcellen stabiel is, ongeacht of de hartcel zich op een endocardiale, een mesocardiale, dan wel een epicardiale locatie bevindt. Dit is belangrijk wanneer kwantitatieve conclusies moeten worden getrokken aan de hand van uitscheidingsgrafieken van deze merkers. Een belangrijke negatieve correlatie werd gevonden tussen de hartmassa en de concentratie van al deze vier genoemde merkers in het weefsel als gevolg van cardiale hypertrophie (zie hoofdstuk 4).

Samen met enzymatische data zijn de concentraties van myoglobine, vetzuurbindend eiwit en troponine $T$ in het plasma nuttig om hartweefselschade na acuut myocardinfarct te kunnen vaststellen. Op grond van een kleinere weefselspreiding hebben de merkers melkzuur dehydrogenase, hydroxyboterzuur dehydrogenase en vetzuur-bindend eiwit enige voorkeur ten opzichte van myoglobine of troponine-T. Echter op grond van specificiteit of de mate van uitscheiding zou de voorkeur kunnen uitgaan naar een van de andere merkers.

Daar de mate van hartspierschade gerelateerd is aan de prognose van de levensverwachting voor de patiënt, is deze zeer belangrijk. Enzymatisch vaststellen van de mate van ischaemische hartspierschade is een routine klinische handeling geworden en is op succesvolle wijze toegepast in de evaluatie van de trombolytische therapie. Hierbij is aangetoond, dat de gunstige effecten van de behandeling, n.l. bescherming van de hartspierfunctie en reductie in mortaliteit, kunnen worden verklaard uit de beperking van de infarctgrootte. Dit heeft bijgedragen tot de interesse in de kwantitatieve interpretatie van enzymbepalingen en de methodologische aspecten van een dergelijke analyse.

Buiten onze studie zijn ons geen andere studies bekend over de kwantificering van cardiaal troponine $T$ uitscheiding en slechts weinige over de kwantificering van myoglobine en vetzuur-bindend eiwit uitscheiding in het plasma. In hoofdstuk 2 rapporteren wij over onze studie met betrekking tot de mate van het vrijkomen van troponine $T$ in vergelijking met de uitscheiding van cytoplasmatische cardiale enzymen bij 22 patiënten met een acuut myocardinfarct, die trombolytische therapie ondergingen. Zawel creatine kinase, hydroxyboterzuur dehydrogenase, melkzuur dehydrogenase als troponine $T$ werden seriematig bepaald in bloedmonsters die zeer frequent en gedurende minstens 168 uur na de start van trombolytische therapie bij patiënten waren verkregen. De cumulatieve uitstortingscurves van de enzymen en troponine $T$ in het plasma werden gecalculeerd, gebruikmakend van een zogenaamd twee compartimenten madel voor circulerende eiwitten. De cumulatieve plasma uitstorting en de op grond hiervan berekende infarctgrootte, werd uitgedrukt in gram equivalent $(g$-eq) gezond myocard per liter plasma. Hierbij werd uitgegaan van een 
gemiddelde hoeveelheid troponine $T$ in hartspierweefsel van $234 \mathrm{mg}$ per gram gezond hartweefsel. Bij de cardiale enzymen creatine kinase, hydroxyboterzuur dehydrogenase en melkzuur dehydrogenase nam de totale uitscheiding na 72 uur niet verder toe. De verschillen tussen deze enzymmerkers waren niet significant. De cumulatieve uitstorting van troponine $T$ echter, uitgedrukt in gram equivallenten myocard per liter plasma, was slechts $5 \%$ van de totale uitstorting ( $g$-eq) van de cytoplasmatische cardiale enzymen na 72 uur en nam verder toe tot $8,5 \%$ na 168 uur. Dit kan worden verklaard uit het feit, dat de cytosole fractie van troponine $T$ in vers hartspierweefsel slechts $4 \%$ van de totale hoeveelheid troponine $T$ is en dat deze fractie in een vroeger stadium wordt uitgestort in vergelijking met de troponine $T$ fractie die gebonden is aan de myofibrillaire structuren. De verschillende uitstortingspatronen voor enerzijds de vrije cytosolische troponine $T$ fractie en anderzijds de gebonden troponine $T$ fractie, kunnen een bifasische plasma uitstortingscurve veroorzaken, met name bij patiënten die een vroege reperfusie vertonen na een acuut myocardinfarct. Ondanks de incomplete uitstorting van troponine T blijken de waarde van cumulatieve troponine T na 72 en 168 uren en de troponine $T$ piekwaarden goed te correleren met de enzymatische infarctgrootte, uitgedrukt in gram equivalent hartspierweefsel per liter plasma ( $\mathrm{g}$-eq/l) en berekend vanuit cumulatieve hydroxyboterzuur dehydrogenase, melkzuur dehydrogenase of creatine kinase uitstorting. Het feit dat troponine T waarden nog verhoogd zijn in het serum van patiënten na acuut myocardinfarct, terwijl de waarden van andere cardiale merkers reeds genormaliseerd zijn, maakt troponine $T$ een goede merker om hartspierschade te bepalen lange tijd nadat die schade is ontstaan. Dit is waarschijnlijk het geval bij patienten met een syndroom van instabiele angina pectoris, die in de voorafgaande dagen een vorm van hartspierschade hebben doorgemaakt, welke alleen kan worden vastgesteld met een merker als troponine $T$, die gedurende tenminste twee tot drie weken na een hartinfarct verhoogd blijft.

\section{De invloed van verschillende behandelmethoden op de uitstortingspatronen van cardiale merkers bij patiënten met een acuut myocardinfarct}

Er zijn tegenwoordig verschillende behandelingen mogelijk voor verschillende categorieën patiënten, zodra de diagnose acuut myocardinfarct is gesteld. De keuze voor een bepaald behandelregime is afhankelijk van overwegingen zoals leeftijd, medische voorgeschiedenis, klinische toestand en de locatie van het infarct. Derhalve kunnen het begin en de wijze van behandeling verschillen. Bij iedere behandeling is het echter van vitaal belang geïformeerd te zijn omtrent de grootte van het infarct. Daar biochemische merkers worden gebruikt om de infarctgrootte te bepalen, is onderzoek gedaan naar de invloed van het behandelregime op de wijze waarop de merker wordt uitgestort bij twee groepen patiënten (hoofdstulk 3). De eerste groep 
patiënten werd behandeld met trombolyse. De tweede groep om verschillende redenen niet. Binnen 24 uur vond coronairangiografisch onderzoek plaats bij alle patienten die trombolytische therapie hadden ontvangen. Op grond hiervan werden zij verdeeld in een groep met en een groep zonder reperfusie. Bij patienten die niet werden behandeld met trombolyse werd het optreden van reperfusie vastgesteld op klinische symptomen wanneer geen coronairangiogram was gedaan. Daar troponine $T$ gebonden is aan myofibrillaire structuren in de hartspier is het mogelijk dat een behandelingsstrategie of het resultaat van de behandeling - zoals bijvoorbeeld het wel of niet optreden van reperfusie - de cumulatieve plasma uitstorting van dit eiwit op een verschillende wijze beinvloedt in wergelijking met de cumulatieve uitstorting van de niet gebonden cytoplasmatische cardiale enzymen. Voor deze laatsten is aangetoond, dat de totale cumulatieve uitstorting na 72 uur niet wordt beinwloed door de wijze van behandeling. Daarom werd in beide groepen patienten de cumulatieve uitstorting van troponine $T$ vergeleken met de cumulatieve uitstorting van de cytoplasmatische cardiale enzymen hydroxyboterzuur dehydrogenase en creatine kinase. Wij toonden aan, dat de enzym uitstorting binnen 72 tot 100 uur bij alle patiënten compleet was, terwijl de troponine $T$ uitstorting na. 168 uur nog steeds voortduurde. Vertraagde tijd/piekwaarden werden gevonden voor de cardiale enzymen en voor troponine $T$ bij patiënten die niet werden behandeld met trombolytische therapie en die geen reperfusie vertoonden in vergelijking met patiënten die behandeld werden met trombolytische therapie en wel reperfusie vertoonden. Het bleek dat plasma tijd/concentratiecurves en uitstortingsgrafieken van troponine $T$ in patiënten behandeld met trombolytische therapie, die repierfusie vertoonden, een veel duidelijker bifasisch karakter hadden dan de curves van patiënten zonder trombolytische therapie, die geen reperfusie vertoonden. Dit laatste kan echter niet worden gebruikt om vaatdoorgankelijkheid aan te tonen bij patiënten, die trombolytische therapie hebben ondergaan. Desalniettemin werd, ondanks het feit dat de troponine $T$ uitstorting na 168 uur slechts een fractie (ongeveer $8 \%$ ) van de cumulatieve enzym uitstorting bedraagt, een hoge correlatie gevonden tussen de cumulatieve cardiale enzymuitstorting (infarctgrootte) en de cumulatieve troponine $T$ uitstorting. Dit was onafhankelijk van de behandelstrategie of de uitkomst van de behandeling. Wij concludeerden, dat troponine $T$ een betrouwbare merker is om de mate van hartspierschade te bepalen en dat de cumulatieve uitstorting niet wordt beinvloed door de behandelstrategie of de uitkomst wan de behandeling.

\section{Vroege merkers en de invloed van de nierfunctie}

De zogenaamde vroege merkers voor het aantonen van ischaemie van het. myocard worden gekenmerkt door een snelle uitstorting, i.e. een vroeg vrijkomen uit. afstervende hartweefselcellen in het bloed. Het myoglobine en het vetzuur-bindend eiwit zijn cytoplasmatische eiwitten met een laag moleculair gewicht en zij worden beschouwd als nuttige biochemische merlkers voor het vroegtijdig aantonen of 
uitsluiten van een acuut myocardinfarct. Beide eiwitten worden niet alleen snel na het ontstaan van een acuut myocardinfarct in het plasma uitgestort; hun lage molecuulgewicht heeft tevens een klaring via de nier cot gevolg, waardoor hun transittijd in het plasma relatief kort is. De plasmaconcentratie is afhankelijk van een adequate nierfunctie. Een verminderde nierfunctie kan een verhoogde concentratie van deze merkers in het plasma tot gevolg hebben. Door de snelle uitstorting van deze laagmoleculaire eiwitten in het plasma zijn deze eiwitten niet alleen geschikt voor vroegdiagnostick van een acuut myocardinfarct, maar derhalve ook om een acuut myocardinfarct in een vroeg stadium uit te sluiten. Door hun snelle uitstorting kan de grootte van een acuut myocardinfarct in een vroeg stadium worden vastgesteld en op basis van het verloop van de initiëlle curves kan reperfusie worden vastgesteld, nadat trombolyse is gegeven. Bij een verminderde nierfunctie kunnen echter verhoogde concentraties van myoglobine en vetzuur-bindend eiwit worden gevonden, zonder dat er beschadigd myocard bestaat. Dit kan ertoe lijden dat de infarctgrootte, op basis van deze concentraties berekend, wordt overschat, wanneer deze wordt vergeleken met een berekening op basis van merkers met een hoog molecuulgewicht, zoals creatine kinase en hydroxyboterzuur dehydrogenase, die niet via de nieren worden geklaard.

In hoofdstuk 5 bestudeerden we de invloed van een verminderde nierfunctie op de berekende infarctgrootte, wanneer die op basis van plasma uitstortingscurves van cardiale eiw"tmerkers met een laag molecuulgewicht zoals vetzuur-bindend eiwit en myoglobine is gecalculeerd. We vergeleken de verkregen waarden met metingen, verkregen uit betrouwbare merkers van infarctgrootte als hydroxyboterzuur dehydrogenase en creatine kinase, die niet via de nieren worden geklaard. Het verschil in infarctgrootte, gemeten met hetzij myoglobine of vetzuur-bindend eiwit, of met de waarden verkregen uit de traditionele cardiale merkers creatine kinase en hydroxyboterzuur dehydrogenase, was gerelateerd aan de nierfunctie van deze patiënten. Voor dit laatste was de serum creatininewaarde als parameter gebruikt.

In feite toonden we een correlatie aan tussen de plasma creatinineconcentratie in de eerste vierentwintig uur na een acuut myocardinfarct en het verschil in berekende infarctgrootte, enerzijds op basis van cumulatieve uitstortingscurves van myoglobine of vetzuur-bindend eiwit en anderzijds van hydroxyboterzuur dehydrogenase in het plasma.

Bij patiënten, wier creatinineconcentraties in het plasma binnen de normaalwaarden van het laboratorium vielen, vonden we een goede overeenkomst tussen de infarctgrootte, berekend op basis van cumulatieve plasmacurves van myoglobine en vetzuur-bindend eiwit en de infarctgrootte, berekend op cumulatieve plasmacurves van hydroxyboterzuur dehydrogenase. Viel de creatinineconcentratie echter boven de normaalwaarde van het laboratorium, dan werd de infarctgrootte, berekend op basis van cumulatieve plasmacurves van myoglobine en vetzuur-bindend eiwit, met name bil grotere infarcten aanzienlijk overschat. Het belang van deze bevindingen is duidelijk. Wanneer de infarctgrootte wordt berekend op basis van plasmacurves van myoglobine of vetzuur-bindend eiwit dient men zich te realiseren 
dat het vaak voorkomt, dat de nierfunctie in de eerste vierentwintig uur na een acuut myocardinfarct is verminderd. Hierdoor kan een foutieve waarde voor de infarctgrootte worden vastgesteld. Het is dan ook aan te bevelen de nierfunctie zorgvuldig, d.w.z. twee keer in de eerste vierentwintig uur te bepalen, wanneer men laagmoleculaire eiwitmerkers gebruikt om de infarctgrootte te berekenen.

\section{Conclusies}

- In normaal hartspierweefsel ligt de variatie van de hoeveelheid troponine T. vetzuur-bindend eiwit, myoglobine, melkzuur dehydrogenase en hydroxyboterzuur dehydrogenase in de orde van $15 \%$ en zijn deze eiwitten transmuraal gelijkelijk verdeeld. Hieruit kan worden afgeleid, dat de localisatie van het infarct van weinig invloed is op de bepaling van de grootte van het infarct.

- De cumulatieve troponine $T$ uitstorting bedraagt slechts een fractie van de cumulatieve uitstorting van de cardiale enzymen ( $5 \%$ na 72 uur en $8,5 \%$ na 168 uur). Toch werd een goede correlatie gevonden tussen de uitstorting van troponine $T$ en de cytosole cardiale enzymen bij patiënten met een acuut myocardinfarct. Daar troponine $T$ tot tenminste 170 uur na het begin van de klachten in de circulacie wordt uitgestort, is het klaarblijkelijk een goede merker voor het detecteren van celversterf wanneer de patiènt zich pas na lange tijd presenteert op de eerste hulp. Dit is vooral van belang omdat andere merkers zoals het electrocardiogram en de anamnese vaker geen diagnose meer mogelijk maken, b.v. wanneer op het electrocardiogram al een vroeger doorgemaakt infarct of een linker bundeltakblock zichtbaar is.

- De mate van cumulatieve troponine T uitstorting wordt niet beinvloed door trombolytische therapie of het wel of niet doorgankelijk zijn van het infarctgerelateerde coronairvat.

- De cumulatieve uitstorting van de eiwitten met een laag moleculair gewicht, zoals myoglobine en vetzuur-bindend eiwit is binnen 24 uur na het begin van de symptomen voltooid. De uitstorting van de cytoplasmatische cardiale enzymen met een hoog moleculairgewicht zoals creatine kinase en hydroxyboterzuur dehydrogenase duurt daarentegen 72 uur. Uit de gegevens welke zijn gerapporteerd in hoofdstuk $5 \mathrm{kan}$ worden geconcludeerd, dat al na $\| 0$ uur een betrouwbare berekening van de infarctgrootte kan worden gemaakt op basis van het vetzuur-bindend eiwit.

- Daar de berekende cumulatieve uitstorting van merkers met een laag moleculairgewicht kan worden beïnloed door de nierfunctie dient deze, wanneer de infarctgrootte binnen 24 uur na het begin van de klachten op basis van dit soort merkers wordt berekend, onder de $120 \mu \mathrm{mol} / \mathrm{L}$ te liggen. Bij nierfunctiewaarden boven deze grens dient een aangepaste berekening plaats te vinden. 
- In de huidige studie werd de hoeveelheid myocardiaal eiwit in gezonde harten bepaald, terwijl de harten van patiënten, die overleden na een myocardinfarct lagere hoeveelheden van deze eiwitten bevatten. Uit hoofdstuk 5 blijkt, dat de ratios van de uitgestorte cytosolische eiwitten overeenstemmen met de ratios van gezonde harten. Hieruit kan worden vastgesteld, dat de pathologische veranderingen, zoals die worden gezien in de harten van patiënten met een acuut myocardinfarct berusten op dilutie van normaal spiercelweefsel d.m.v. collageen, vet en oedeem.

- De enzymactiviteit is in het algemeen gevoelig voor perturbatie van de tertiaire structuren van het molecuul. De antigene epitopen in het myoglobine en het vetzuur-bindend eiwit, die worden gebruikt in immunoassays zijn daarentegen vaste en stabiele structuren. Desalniettemin worden bij het berekenen van de infarctgrootte gelijke waarden gevonden voor enzymatische en niet-enzymatische eiwitten. Dit houdt in dat de denaturatie van het eiwit vóór de cellulaire uitstorting alsmede tijdens het transport van het hart naar het plasma beperkt moet zijn. 
Appendix 


\section{List of publications}

\section{Publications, related to this thesis}

Van Diejjen-Visser MP, Kragten JA, Glatz JFC Hermens WTh. Clinical relevance of early markers for the diagnosis of acute myocardiall infarction (AMI).

Tijdschrift Ned. Ver. Klinische Chemie, 1993:3:140-4.

Van Nieuwenhoven FA, Kleine AH. Wodzig KWH. Hermens WTh, Kragten JA, Maessen $H G$, Punt CD, Van Dieijen-Visser MP, Van der Gusse G], Glatz JFC. Discrimination between myocardial and skeletal muscle injury by assessment of the plasma ratio of myoglobin over fatcy acid-binding protein. Circulation 1995;92:2848-54.

Kragten JA, Van Dieijen-Visser MP, Hermens WTh. Diagnostiek en vroegdiagnostiek van het myocardinfarct. De rol van nieuwe biochemische merkers. Cardiogram \996; $1: 3-5$

Van Dieijen-Visser MP, Wodzig KWH, Kragten JA, Hermens WTh. Troponine T uitstorting in plasma na een acuut myocardinfarct. Ned. Tijdschrift Klin. Chemie 1996; $21: 22-8$.

Kragten JA, Van Nieuwenhoven FA, Van Dieijen-Visser MP. Theunissen PHHM, Hermens WTh, Glatz JFC. Distribution of myoglobin and fatty acid-binding protein in human cardiac autopsies. Clin. Chem. 1996; 42: 333-8.

Kragten JA, Hermens WTh, Van Dieijen-Visser MP. Cardiac troponin T release into plasma after acute myocardial infarction: only fractional recovery compared with enzymes. Ann. Clin. Biochem. 1996; 33: 1-10.

Wodzig KWH, Kragten JA, Hermens WTh, Glatz JFC, Van Dieijen-Visser MP. Estimation of myocardial infarct size from plasma myoglobin of fatty acid-binding protein. Influence of renal function. Eur. J. Clin. Biochem. 1997; 35(3):191-8.

Kragten JA, Hermens WTh, Van Dieijen-Visser MP. Cumulative troponin $T$ release after acute myocardial infarction (AMI). Influence of reperfusion.

Eur. J. Clin. Chem. Clin. Biochem. 1997; (6): 459-67.

Glatz JFC, Van der Vusse G], Simoons ML, Kragten JA, Van Dieijen-Visser MP. Hermens WTh. Fatty acid-binding protein and the early detection of acute myocardial infarction. Submitted.

Wodzig KWH, Kragten JA. Modrzejewski W, Gorski J, Van Dieijen-Visser MP, Glatz JFC, Hermens WTh. Thrombolytic therapy does not change the release ratios of enzymatic and non-enzymatic myocardial marker proteins. Submitted.

\section{Abstracts}

Van Dieijen-Visser MP, Kragten JA, Glatz JFC, Hermens WTh.

Release kinetics of myoglobin fatty-acid binding protein and troponin $T$ after acute myocardial infarction. Comparison with cardiac enzymes. Tijdschrift NVKC 1993; 18; 100.

Kragten JA, Van Dieijen-Visser MP, Glatz JFC and Hermens WTh.

Myoglobin and early markers after AMI. Comparison with cardiac enzymes and Troponin T. 5 th Int Symp Belgian Soc Clin Chem. 1993; pp. 13. 
Van Dieijen-Visser MP, Kragten JA, Glatz JFC, Van Nieuwenhoven FA, Theunissen PHMH and Hermens WTh. Content of enzymes (LDH, HBDH) and non-enzymatic proteins (myoglobin, FABP, troponin T) in cardiac tissue. Significance for the assessment of tissue injury from data on plasma concentrations. Ned Tijdschr Klin Chem 1995; 20; 119.

Van Diejen-Visser MP, Kragten JA, Westerhuis LWJJM and Hermens WTh. Quantification of troponin $T$ release in plasma after acute myocardial infarction. Ned Tijdschr Klin Chem $1995 ; 20 ; 120$.

Wodzig KWH, Pelsers MMAL, Kragten JA, Van Dieijen-Visser MP, Hermens. WTh, Van der Vusse GJ and Glatz JFC. Fatty-acid binding protein and myoglobin as diagnostic plasma markers of acute myocardial infarction in humans. Ned Tijdschr Klin Chem 1995; 20; 119-20.

Van Dieijen-Visser MP, Kragten IA, Glatz JFC, Van Nieuwenhoven FA, Theunissen PHMH and Hermens WTh. Content of enzymes (LDH, HBDH) and non-enzymatic proteins (myoglobin, FABP, troponin T) in cardiac tissue. Significance for the assessment of tissue injury from data on plasma concentrations. Book of abstracts werkgroep cardiologische centra Nederland 1995; pagina 18.

Kragten JA, Van Dieijen-Visser MP. Westerhuis LWJJM and Hermens WTh. Quantification of troponin $T$ release in plasma after acute myocardial infarction. Book of abstracts werkgroep cardiologische centra Nederland 1995, pagina 19.

Kragten JA, Wodzig KWH, Pelsers MMAL, Van Dieijen-Visser MP. Hermens WTh, Van der Vusse G) and Glatz JFC. Fatty-acid binding protein and myoglobin as diagnostic plasma markers of acute myocardial infarction in humans. Book of abstracts werligroep cardiologische centra Nederland 1995, pagina 18.

Wodzig KWH. Pelsers MMA, van Dieijen-Visser MP, Kragten JA, Hermens WTh, van der Vusse GJ and Glatz JFC. Fatty acid-binding protein as a predictive indicator of acute myocardial infarct size in thumans. European Society of Cardiology aug. 1995; 20-4 " Amsterdam. Eur Heart J 1995; 16; 42.

J. Kragten, W. Hermens, M. Van Dieijen-Visser. Cumulative troponin T release in patients treated with and without thrombolytic therapy; comparison with enzyme release. Book of abstracts werkgroep cardiologische centra Nederland 1996. pagina 52.

Wodzig KWH "Pelsers MMAL, Van Diejen-Visser MP, Kagten JA, Vander Vusse GJ en Glatz JFC. Vetzuurbindend eiwir als niet enzymatische meitker voor schatting van de grootte van thet acuut myocardinfarct bij de mens. Ned Tijdschi Geneesk 1996; 140; 2315-16.

Wodzig KWH, Pelsers MMAL, Van Dieijen-Visser MP, Kragten JA, Hermens WTH, Van der Vusse GJ and Glats JFC. Fatty-acid binding protein as predictive non-enzymatic marker of acute myocardial infarct size in humans. Tijdsch Ned Ver Klin Chem 1996; 21; 98 -9. 


\section{Publications not related to this thesis}

Kragten \A $A_{4}$ Hendriks \. Al uw vragen over hartziekten. Ie druk 1986, 2e druk 199.. ISBN 9027495122 NUGI 732 Het Spectrum, Utrecht.

Kragten JA. Hart hebben voor je nieren. Wisselwerking 1995; 19:40-1.

Kool M, Lustermans F, Kragten J. Struyker Boudier H, Hoeks A, Reneman R, Rila $H$, Hoogendam 1, Van Bortel L. Does lowering of cholesterol levels influence functional properties of large arteries? Eur. Clinic. Pharmacol. 1995; 48: 217-23.

Kragten JA, Van den Berg CJM. ACE-remmers na het infarct, woor iedereen zinvol ? Cardiogram 1996; 3:20.5.

Michels BC, Al MJ, Remme WJ, Kingma HJ, Kragten JA, Van Nieuwenhuizen R, Van Hout BA. Economic aspects of treatment with captopril for patients with asymptomatic left ventricular dysfunction in The Netherlands. Eur. Heart J. 1996; 17: 731-40.

Goey R, Rommen HR, Kessels AH, Kragten JA. Diagnosis via ultrasonography of the inferior vena cava and hepatic veins. Fortschr. Rontgenstr. 1997; 166 (I): 36-9.

Kragten $J A$, Vincent $C A$, Research and Development, een apart vak of een vak apart ?

Cardiogram $\| 997 ; 13: 22-3$.

Dunselman $P$, Liem AH, Verdel G, Kragten JA, Bosma A, Bernink $P$, on behalf of the FEMINA study group of the Working Group on Cardiovascular Research, The Netherlands (WCN). Addition of Felodipine to Metoprolol or Felodipine in patients with Angina Pectoris despite adequate Beta Blockade. Eur. Heart J. 1997; 18: 1755-64. 


\section{List of abbreviations}

$\begin{array}{ll}\text { ADP } & \text { Adenosine DiPhosphate } \\ \text { ALAT } & \text { ALanine Amino Transferase } \\ \text { AMI } & \text { Acute Myocardial Infarction } \\ \text { AP } & \text { Angina Pectoris } \\ \text { ASATIAST } & \text { ASpartate Amino Transferase } \\ \text { ATP } & \text { Adenosine TriPhosphate } \\ \text { CABG } & \text { Coronary Artery Bypass Grafting } \\ \text { CI } & \text { Confidence Interval } \\ \text { CK } & \text { Creatine Kinase } \\ \text { CK-MB } & \text { Creatine Kinase isoenzyme MB } \\ \text { CRP } & \text { C-Reactive Protein } \\ \text { DGKC } & \text { Deutsche Gesellschaft für Klinische Chemie } \\ \text { ECG } & \text { ElectroCardioGram } \\ \text { EDTA } & \text { Ethylene Diamine Tetra Acetic acid } \\ \text { ERR } & \text { Extravascular Return Rate } \\ \text { FABP } & \text { Fatty Acid-Binding Protein } \\ \text { FCR } & \text { Fractional Catabolism Rate } \\ \text { G-6-PDH } & \text { Glucose-6-Phosphate DeHydrogenase } \\ \text { a-HBDH } & \text { a-HydroxyBtyric acid DeHydrogenase } \\ \text { IFCC } & \text { International Federation of Clinical Chemistry } \\ \text { Kd } & \text { Kilodalton } \\ \text { LD (LDH) } & \text { Lactate DeHydrogenase } \\ \text { Mb } & \text { Myoglobin } \\ \text { MW } & \text { Molecular Weight } \\ \text { NAD } & \text { Nicotine Adenine Dinucleotide } \\ \text { NADP } & \text { Nicotine Adenine Dinucleotide Phosphate } \\ \text { NVKC } & \text { Nederlandse Vereniging voor Klinische Chemie } \\ \text { PTCA } & \text { Percutaneous Transluminal Coronary Angioplasty } \\ \text { PV+ } & \text { Positive Predictive Value } \\ \text { PV- } & \text { Negative Predictive Value } \\ \text { ROC } & \text { Receiver Operating Characteristics } \\ \text { SD } & \text { Standard Deviation } \\ \text { SE } & \text { Standard Error } \\ \text { TER } & \text { Transcapillary Escape Rate } \\ \text { TnI } & \text { Tropinin I } \\ \text { TnT } & \text { Troponin T } \\ \text { UAP } & \text { Unstable Angina Pectoris } \\ \text { URL } & \text { Upper Reference Limit } \\ \text { WCN } & \text { Werkgroep Cardiologische Centra Nederland } \\ \text { WHO } & \text { World Health Organization } \\ & \end{array}$




\section{Dankwoord}

'Concordia res parvae crescunt': door samenwerking groeien kleine zaken. Deze oude spreuk is zonder meer van toepassing op de ontwikkeling van dit proefschrift. Ook al staat nu mijn naam op de omslag van dit boek, het proefschrift dat voor $u$ ligt is een product van de energie en inzet van vele mensen, die mij enorm geholpen hebben om dit resultaat te bereiken. Zonder volledig te kunnen zijn, wil ik graag een aantal mensen bedanken die een belangrijke bijdrage aan dit proefschrift hebben geleverd.

Hooggeleerde Van Dieijen-Visser, beste Marja: al in de tijd dat je nog in Heerlen werkte, werd de basis van dit proefschrift gelegd. Samen hebben we het protocol geschreven, op dat moment nog niet beseffend dat dit tot een proefschrift zou leiden. Op charmante en heldere wijze heb je me stap voor stap door dit project geleid. Je hebt me op momenten dat ik het echt niet meer zo zag zitten over de (Limburgse) heuvels heengetrokken. Dat jouw inzet van levensbelang is geweest voor dit proefschrift behoeft geen verder betoog. Het is voor mij een grote eer de eerste promovendus te mogen zijn van jouw hoogleraarschap.

Hooggeleerde Hermens, beste Wim: al mijn artikelen, die als hoofdstuk in dit proefschrift zijn opgenomen, dragen mede jouw naam. Jij zorgde ervoor dat de cijfers klopten en ook in de laatste fase van het onderzoek heb je mij enorm geholpen met het inleidende hoofdstuk. Mede door jouw bijdrage heb ik geleerd, dat geneeskunde en wetenschap niet altijd hetzelfde zijn. Het is voor mij heel bijzonder, ook voor jou de eerste promovendus van je professoraat te mogen zijn.

Hooggeleerde Brombacher, beste Paul: jouw voorspelling is uitgekomen, omidat ik het recept heb gevolgd, dat iij me al jaren terug hebt gegeven. Dat jij pas serieus aan de slag ging nadat je toestemming van Agnes had gekregen, bewijst je mensenkennis. De zondagmiddagen op jouw kamer met de thee en korkjes van je echtgenote maakten het beoefenen van wetenschap gezellig, terwijl door mij gesignaleerde problemen voor jou niet meer dan een uitdaging vormden. lk dank je voor het vele dat jij me hebt geleerd.

Hooggeleerde Wellens, beste Hein: je hebt mijn proefschrift zeer kritisch doorgelezen en de wijzigingen van jouw hand heb ik volgaarne in de tekst opgenomen. Het is voor mij een grote eer, dat je dit ondanks je drukke leven hebt willen doen. Ik hoop dat dit proefschrift een bijdrage kan vormen in de verdere samenwerking tussen de afdelingen Cardiologie van Maastricht en Heerlen. Ik wil je hartelijk danken voor je bijdrage.

Hooggeleerde Robles de Medina, beste Etienne: als geboren en getogen Utrechter hechtte ik sterk aan een Utrechtse component in de beoordeling van dit proefschrift. Daarom heb ik je inbreng in de beoordeling van het manuscript en de oppositie zeer gewaardeerd. Ik dank je yoor je bereidheid naar Zuid-Limburg te komen om dit alles mee te maken. 
Ook de overige leden van de beoordelingscommissie, prof. Van der Laarse en prof. Van der Vusse, dank ik voor de bereidheid mijn werk te beoordelen en de oppositie te voeren.

Voor mijn onderzoek met het FABP heb ik dankbaar gebruik mogen maken van de gegewens van dr. Jan Glatz. Ook zijn morele ondersteuning was van groot belang voor het uiteindelijke resultaat dat thans voorligt. Jan, mijn hartelijke dank daarvoor.

De tweeënvijftig patienten, die toestemming gaven om vele monsters bloed aan de wetenschap af te staan dank ik woor hun bereidheid de daar aan gekoppelde ongemakken te doorstaan.

De verpleegkundigen van de CCU in Heerlen hebben bijna een jaar lang moeite gedaan voor de 'Troponinetrial' en zij vulden vele buisjes met het bloed, dat de gegevens voor dit proefschrift heeft geleverd. Jullie allemaal dank ik voor de bereidheid, deze werkzaamheden 'pro Deo' voor mij te hebben verricht.

Marijke Koenders-Delnoy en Mia van der Vloet-Boermans, als analist werkzaam op ons klinisch chemisch laboratorium, hebben de talloze analyses verricht, waarop de gegevens van dit proefschrift zijn gefundeerd. Graag wil ik jullie nog eens hartelijk danken voor de vanzelfsprekende nauwkeurigheid en het enthousiasme waarmee jullie dit alles hebben gedaan.

De leden van de maatschap Cardiologie Heerlen-Brunssum hebben vaak voor mij waargenomen, als ik weer eens voor een 'vluggertje' naar Maastricht was gevlogen. Graag will ik jullie hartelijk danken voor de mogelijkheid, die jullie mij hebben geboden om dit proefschrift in een 'perifeer' functionerende afdeling cardiologie te schrijven.

Het secretariaat van onze afdeling heeft meerdere keren in alarmfases acute nood gelenigd door vastgelopen bestanden weer vlot te trekken, of zelfs gedeeltelijk opnieuw te typen. Dankzij jullie werden onmogelijke deadlines toch steeds weer gehaald.

Bureau Public Relations van Ziekenhuis De Wever \& Gregorius en St. Jozef in Heerlen heeft ervoor gezorgd, dat de aangeleverde teksten uiteindelijk tot een boek zijn geworden. Met name Ingrid Heller bleef steeds maar glimlachen, als ik weer eens een gereviseerde tekst aanleverde voor de 'laatste' wijzigingen. Ingrid, hartelijk dank voor het vertrouwen, dat je in mij bleef stellen!

Mijn (schoon)vader, Jaap Hendriks, heeft het hele manuscript kritisch doorgelezen en met name de Nederlandse tekst ontdaan van stijl- en taalfouten. Jaap, dit boek is eigenlijk ons tweede gezamenlijke boek en opnieuw ben ik je veel dank verschuldigd voor je plezierige hulp en steun.

Agnes, nadat iij aan Paul Brombacher toestemming had gegeven mij tot dit proefschrift te verleiden, heb je er steeds achter gestaan, ook wanneer bleek dat alles niet zo vlot ging als wij dachten. Delen van dit proefschrift heb je meerdere keren kritisch doorgelezen en mij gewezen op fouten, die ik over het hoofd zag. Na Joris en Wouter is dit proefschrift eigenlijk ons derde kindje. Dat ik daar zo blij mee ben, is mede gelegen in onze gezamenlijke inzet. Dank je wel! 


\section{Curriculum vitae}

Johannes Albertus (Hans) Kragten werd geboren op 28 november 1952 in Utrecht als de jongste telg uit een gezin van zes kinderen.

De lagere schooljaren bracht hij door op de parochieschool van de St. Ludgeruskerk in Zuilen, inmiddels één van de wijken van de stad Utrecht. In 1965 startte hij zijn opleiding aan het St. Bonifatiuscollege in Utrecht. Het examen Gymnasium Beta (oude still) werd succesvol afgelegd in juni 1971, hetzelfde jaar waarin hij de studie Geneeskunde startte. Al in het eerste jaar van zijn studie aan deze Universiteit trad hij toe tor de werkgroep Introductie \& Studiebegeleiding van de Faculteit der Geneeskunde. Deze werkgroep poogde een bijdrage te leveren aan de kwaliteit van het onderwijs binnen deze faculteit. Ook begon hij in 1971 als weekenden vakantiehulp verplegingsdienst in het St. Antonius-Ziekenhuis te Utrecht, waar hij gedurende een groot deel van zijn studententijd heeft gewerkt. Het Kandidaatsexamen behaalde hij in juni 1974; het Doctoraal examen in juni 1976. De laatste jaren van zijn opleiding tot arts werkte hij op een cardiologische afdeling en verrichtte hij ook vrijwillige stages op verpleegafdelingen van ziekenhuizen in Duitsland (München) en Engeland (Londen). Door deze werkzaamheden werd zijn belangstelling gewekt voor de cardiologische patiënt, later ook zijn eigen patiënten.

De opleiding cardiologie startte Hans Kragten in het St. Antonius-Ziekenhuis op I januari 1979 (opleider Dr. A.V.G. Bruschke). Van I februari 1980 tot 3 I januari 1982 volgde hij de opleiding interne geneeskunde in hetzelfde ziekenhuis bij dr. C.E.M. de Maat. De opleiding werd afgerond op 31 december 1983. Gedurende deze opleiding was hij als docent werkzaam op de opleiding tot A-verpleegkundigen, alsook de voortgezette opleiding CCU- en ICU-verpleegkundigen van dit ziekenhuis. Tevens verzorgde hij de lessen Ziekteleer voor leerlingen in opleiding tot schoonheidsspecialiste volgens de STIVAS-opleiding. Hij was de mede initiator van o.m. een aantal assistentenfeesten, alsook een groot ziekenhuisfeest ter gelegenheid vam de verhuizing van het St. Antonius-Ziekenhuis van Utrecht naar Nieuwegein in 1983.

Op I januari 1984 volgde inschrijving als cardioloog in her specialisten" registratieregister. In mei van datzelfde jaar startte hij als chef de clinique Cardiologie in het De Wever-Ziekenhuis te Heerlen. Vanaf I november 1985 is hij officieel in de maatschap opgenomen. Sedert die tijd is hij als staflid verbonden aan dit ziekenhuis, waar hij inmiddels diverse functies binnen de staf heeft wargenomen (Commissie Intercollegiale Toetsing, Wenckebachcommissie, stafbestuur, secretaris van de medische staf, organisator van vele nascholingsactiviteiten voor huisartsen en collegaspecialisten).

Hans Kragten is in 1985 getrouwd met Agnes Benita Hendriks. Ze hebben twee zonen: Joris (1986) en Wouter (1988). 